\title{
Lebanon: 2007 Article IV Consultation-Staff Report; Staff Statement; Public Information Notice on the Executive Board Discussion; and Statement by the Executive Director for Lebanon
}

Under Article IV of the IMF's Articles of Agreement, the IMF holds bilateral discussions with members, usually every year. In the context of the 2007 Article IV consultation with Lebanon, the following documents have been released and are included in this package:

- $\quad$ The staff report for the 2007 Article IV consultation, prepared by a staff team of the IMF, following discussions that ended on May 28, 2007, with the officials of Lebanon on economic developments and policies. Based on information available at the time of these discussions, the staff report was completed on September 18, 2007. The views expressed in the staff report are those of the staff team and do not necessarily reflect the views of the Executive Board of the IMF.

- $\quad$ A staff statement of October 3, 2007 updating information on recent developments.

- $\quad$ A Public Information Notice (PIN) summarizing the views of the Executive Board as expressed during its October 3, 2007 discussion of the staff report that concluded the Article IV consultation.

- $\quad$ A statement by the Executive Director for Lebanon.

The document listed below has been or will be separately released.

Report on Performance Under the Program Supported by Emergency

Post-Conflict Assistance

The policy of publication of staff reports and other documents allows for the deletion of market-sensitive information.

To assist the IMF in evaluating the publication policy, reader comments are invited and may be sent by e-mail to publicationpolicy@imf.org.

Copies of this report are available to the public from

International Monetary Fund $\bullet$ Publication Services

$70019^{\text {th }}$ Street, N.W. • Washington, D.C. 20431

Telephone: (202) 623-7430 • Telefax: (202) 623-7201

E-mail: publications@imf.org • Internet: http://www.imf.org

Price: $\$ 18.00$ a copy

\section{International Monetary Fund Washington, D.C.}



INTERNATIONAL MONETARY FUND

LEBANON

Staff Report for the 2007 Article IV Consultation

Prepared by the Staff Representatives for the 2007 Consultation with Lebanon

Approved by Juan Carlos Di Tata and Scott Brown

September 17, 2007

- $\quad$ Discussions were held in Beirut May 14-28, 2007. The mission comprised Mr. Gardner (head), Ms. Oner, Messrs. Schimmelpfennig and Sdralevich (all MCD), Finger (PDR), Hoffmann (MCM), and Le Borgne (FAD). Mr. Di Tata (MCD) and Ms. Choueiri (OED) participated in some of the policy discussions. The mission met with the central bank governor, the ministers of finance, economy and trade, tourism, and energy, the Banking Control Commission, senior government officials, the director of the electricity company, and representatives of the banking sector, the business community, the trade union, and donor countries.

- Lebanon accessed Fund resources under Emergency Post-Conflict Assistance (EPCA) (25 percent of quota or SDR 50.75 million) in April 2007. Lebanon has accepted the obligations of Article VIII, Sections 2, 3, and 4 in 1993 and maintains an exchange system free of restrictions on the making of payments and transfers for current international transactions; controls on capital account transactions are minor, and relate mostly to a prohibition on domestic borrowing by nonresidents. The Lebanese pound is de facto pegged to the U.S. dollar; since October 1999, the Banque du Liban has intervened to keep the pound within a narrow corridor of LL 1501 to LL 1514 per U.S. dollar. The 2006 Article IV consultation was concluded by the Executive Board on May 3, 2006.

- $\quad$ Lebanon participates in the General Data Dissemination Standards. The fiscal ROSC was published May 16, 2005, and the last FSAP update was concluded in 2001.

- This report reflects information through May 2007. A progress report on performance under EPCA at end-June 2007 was issued to the Executive Board for information (IMF Staff Country Report No. 07/371) on September 5. A forthcoming staff statement will discuss more recent developments. 


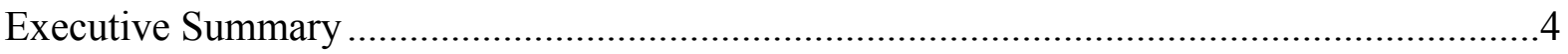

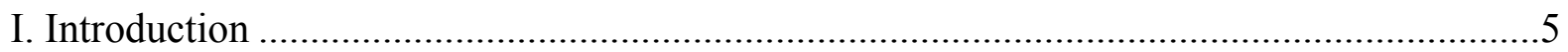

II. Background and Recent Developments ..............................................................

III. Outlook and Authorities' Views on Policies ........................................................

A. Minimizing Risks to the Paris III Reform Strategy .......................................... 8

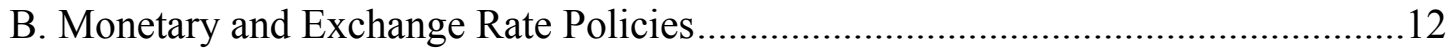

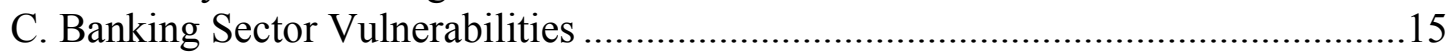

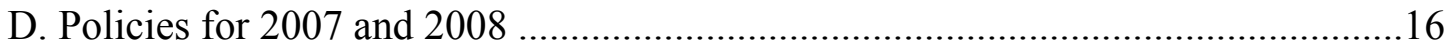

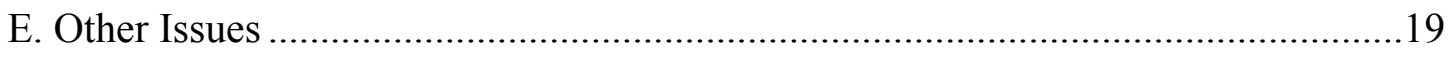

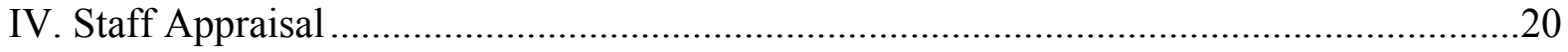

Boxes

1. Implementation of Past Fund Advice ....................................................................5

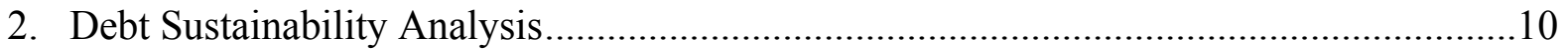

3. Assessment of the Level of the Real Exchange Rate...................................................14

4. Performance Under the Program Supported by EPCA ................................................ 17

5. Energy Sector Reforms ......................................................................................... 19

Figures

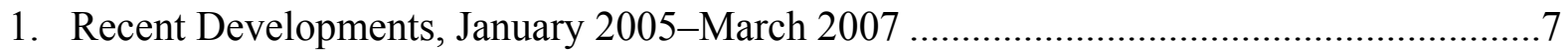

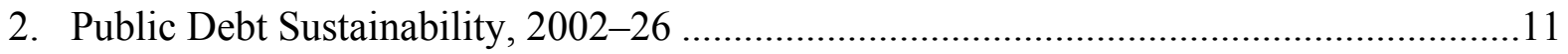

Text Tables

1. Economic Impact of the July-August 2006 Conflict, 2006-09 ...................................6

2. The Paris III Fiscal Adjustment Objectives, 2006-12 ............................................ 9

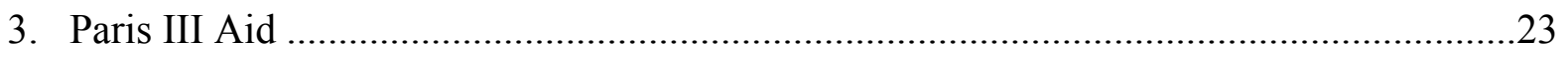

Tables

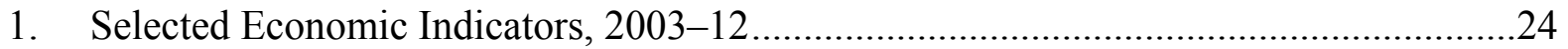

2. Central Government Primary Balance, 2003-08 (In billions of Lebanese pounds) ........25

3. Central Government Primary Balance, 2003-08 (In percent of GDP) .........................26

4. Government Expenditure by Function, 2002-06 .......................................................27

5. Overall Fiscal Deficit and Financing, 2003-08 .....................................................28

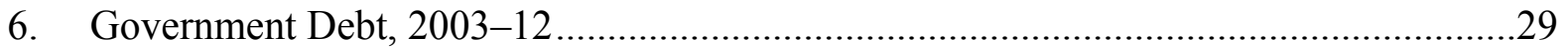

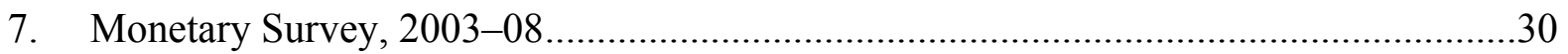

8. Balance Sheet of the Banque du Liban, 2003-08 .................................................... 31 


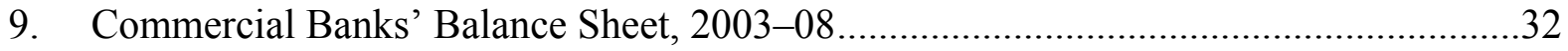

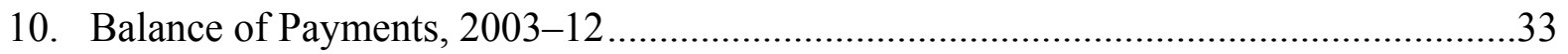

11. Public Sector Debt Sustainability Framework, 2003-26...............................................34

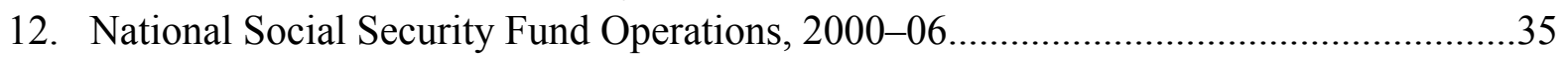

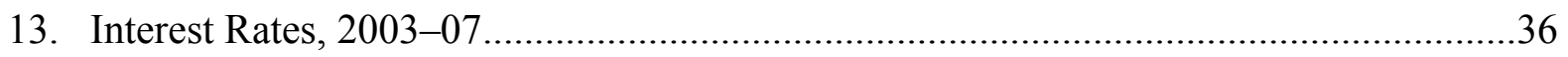

14. Banking Sector Financial Soundness Indicators, 2003-07........................................37

15. Indicators of Financial and External Vulnerability, 2003-07 ......................................38

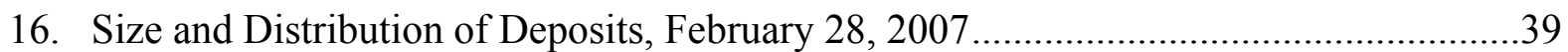

17. Quantitative Indicative Targets Under the EPCA, March-December 2007..................40

18. Monitorable Actions for the Period March-December 2007 ........................................41

19. External Financing Requirements and Sources, 2003-08 ...........................................42

20. Indicators of Capacity to Repay the Fund, 2003-12 ..............................................43 


\section{EXECUTIVE SUMMARY}

\section{Background and recent developments}

The economy is slowly recovering from the 2006 conflict with Israel. A political stalemate continues to paralyze legislative activity, and, combined with repeated security incidents, is weighing negatively on economic activity. Money demand has remained robust. In support of the government's 2007 program, the Executive Board approved EPCA in April 2007.

\section{Outlook and policy discussions}

- $\quad$ The government's five-year reform program lays out an ambitious strategy aimed at reducing Lebanon's large debt overhang and financial vulnerabilities. The strategy is subject to recognized risks from domestic and regional tensions, macroeconomic shocks, contingent fiscal liabilities, and the difficulty of mobilizing political support for sustained adjustment. To address some of these risks, the authorities' fiscal strategy is complemented by structural reforms to promote private sector growth (with privatization at its core) and social sector reforms.

- $\quad$ The objectives of the 2007 program are to contain the budget deficit and to maintain financial stability during this difficult transition year, while preparing for sizeable fiscal adjustment and structural reforms in 2008. Revenue, expenditure and public financial management reforms have been identified; structural reforms in the key power and social sectors are being finalized in collaboration with the World Bank.

- $\quad$ Successful fiscal adjustment would provide an opportunity to strengthen the central bank's balance sheet and reform the monetary policy framework by relying on short-term monetary instruments.

- $\quad$ Banks face balance sheet risks from dollarization and exposure to the sovereign. They are diversifying their portfolio through regional expansion and increased retail lending. The sector appears well prepared for the introduction of Basel II in 2008.

\section{Staff appraisal}

- $\quad$ Performance in the first quarter was consistent with the 2007 program objectives, but the uncertain economic and financial outlook requires monitoring. The authorities rightly intend to create a fiscal buffer through tight expenditure control. Early introduction of a floor on gasoline excises would help safeguard revenues.

- $\quad$ Full implementation of major reforms and adjustment measures planned for 2008 will be important to establish the credibility of the strategy and safeguard external stability over the medium term.

- $\quad$ The exchange rate peg remains key to financial stability, and needs to be supported by the authorities' planned fiscal adjustment as well as greater interest rate flexibility and a strengthening of the central bank's balance sheet. 


\section{INTRODUCTION}

1. The Lebanese authorities presented an ambitious five-year reform program to donors at the Paris III conference in January 2007. The program aims at raising growth, improving living standards, and reducing Lebanon's large debt overhang and financial vulnerabilities, taking account of the special challenges created by the conflict with Israel in July-August 2006. A number of reforms were developed in close consultation with the Fund (Box 1), and, on April 9, 2007, the Executive Board approved the authorities' request for EPCA in support of their 2007 program.

\section{Box 1. Implementation of Past Fund Advice}

Since the Paris II conference of 2003, Fund advice has focused on the implementation of the authorities' medium-term strategy of fiscal adjustment, privatization, and structural reforms. The pace of reform and fiscal adjustment has fallen short of the initial plans and of Fund recommendations because of political instability and insufficient domestic consensus on the reform agenda. The conflict between Hezbollah and Israel in 2006 caused a further setback and led to the authorities' decision to delay most adjustment measures until 2008.

In developing their reform strategy, the authorities have, to a large extent, relied on Fund advice. Most of the tax policy and administration measures, as well as the public financial management reforms, embedded in the revised strategy presented by the authorities at the Paris III conference were developed in close consultation with staff, and have benefited from extensive Fund technical assistance. The Fund has supported the authorities' view that the exchange rate peg remains key to financial stability.

2. Even with the strong fiscal adjustment envisaged for 2008-12, Lebanon will continue to be highly vulnerable to swings in investor confidence, and the level of public debt will remain high for years to come. Against this background, discussions for the Article IV consultation stepped back from the immediate program context and focused on:

(i) making the reform strategy more resilient to inherent risks and potential shocks;

(ii) reforms in the monetary policy framework and banking sector; and (iii) policies for 2007 and 2008 to support the authorities' medium-term objectives.

\section{BACKGROUND AND RECENT DEVELOPMENTS}

3. Economic developments in $\mathbf{2 0 0 6}$ were significantly affected by the conflict with Israel (Tables 1-10). ${ }^{1}$ Real GDP is estimated to have been flat in 2006, with strong growth in the first half offsetting the disruptions created by the conflict (Figure 1). Inflation

\footnotetext{
${ }^{1}$ Developments in 2006 were discussed in more detail in IMF Staff Country Report No. 07/177.
} 
accelerated in July-August, largely reflecting supply shortages during the conflict and the ensuing blockade. Financial pressures were managed effectively owing to the banking system's strong liquidity position. Immediately after the conflict, donors pledged $\$ 1.7$ billion for relief and recovery (mostly at the Stockholm conference in August 2006), and disbursements in 2006 roughly offset the immediate fiscal costs of the conflict (Text Table 1). Nonetheless, the overall fiscal deficit increased in 2006 because of rising interest expenditures and higher than expected transfers to the power company, Electricite du Liban (EdL). Government debt rose to over \$40 billion (178 percent of GDP) at end-2006.

Text Table 1. Lebanon: Economic Impact of the July-August 2006 Conflict, 2006-09 (In billions of U.S. dollars)

\begin{tabular}{lrrrrr}
\hline & 2006 & 2007 & 2008 & $\begin{array}{c}2009 \\
\text { Proj. }\end{array}$ & $\begin{array}{c}\text { Cumulative } \\
\text { Proj. 1/ }\end{array}$ \\
\hline Damage & 2.0 & $\ldots$ & $\ldots$ & $\ldots$ & 2.0 \\
Of which: to housing & 1.1 & $\ldots$ & $\ldots$ & $\ldots$ & 1.1 \\
Budgetary impact & 0.7 & 0.9 & 0.4 & $\ldots$ & 2.0 \\
$\quad$ Estimated conflict-related revenue loss & 0.5 & $\ldots$ & $\ldots$ & $\ldots$ & 0.5 \\
Conflict-related spending & 0.2 & 0.9 & 0.4 & $\ldots$ & 1.5 \\
Grant disbursements (including Stockholm conference) 2/ & 0.7 & 0.6 & 0.2 & $\ldots$ & 1.4 \\
\hline
\end{tabular}

Sources: Lebanese authorities; and Fund staff estimates.

1/ May not add up due to rounding.

2/ Excluding support pledged at the Paris III conference.

\section{Despite continued political uncertainty, economic developments in the first} quarter of 2007 pointed to an incipient recovery. Indicators of economic activity during the first quarter suggest that GDP had recovered, faster than expected, to the level of early 2006. Inflation has receded as the impact of supply shortages during the 2006 conflict is fading out, notwithstanding the depreciation of the U.S. dollar to which the currency is pegged. Due to strong year-on-year import growth, the trade deficit widened in the first quarter of 2007. With lower capital inflows and limited donor disbursements, gross international reserves fell by $\$ 300$ million, to $\$ 11$ billion at end-March. ${ }^{2}$

\section{The political tensions that erupted after the conflict with Israel between the} government and the opposition remain high. If not resolved, the political confrontation could lead to a constitutional crisis by the time of the presidential election later this year. On June 10, the United Nations established a tribunal to investigate the assassination of former Prime Minister Hariri. After a period of calm, the security situation deteriorated again in late May with fighting between the Lebanese army and the Fatah al-Islam militants in northern Lebanon and several bomb explosions in and around Beirut.

\footnotetext{
${ }^{2}$ Excluding gold valuation changes.
} 
Figure 1. Lebanon: Recent Developments, January 2005-March 2007

Growth has been subdued due to the 2006 conflict and the ensuing political tensions.

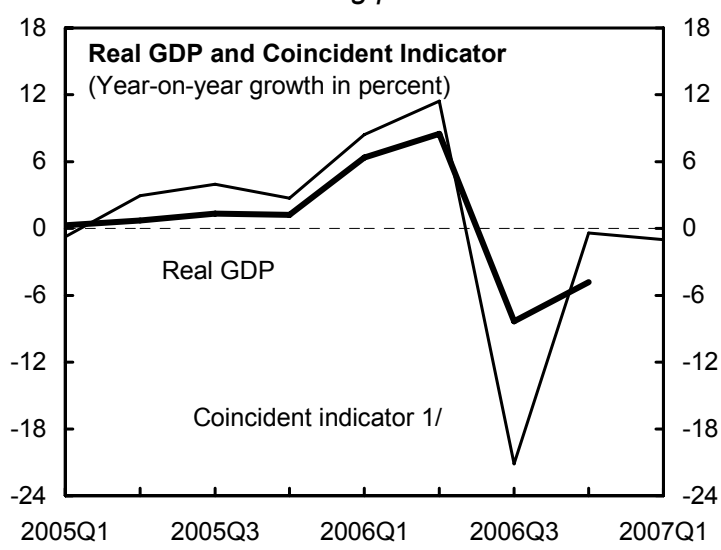

Interruptions of trade flows led to

improved trade balance in 2006.

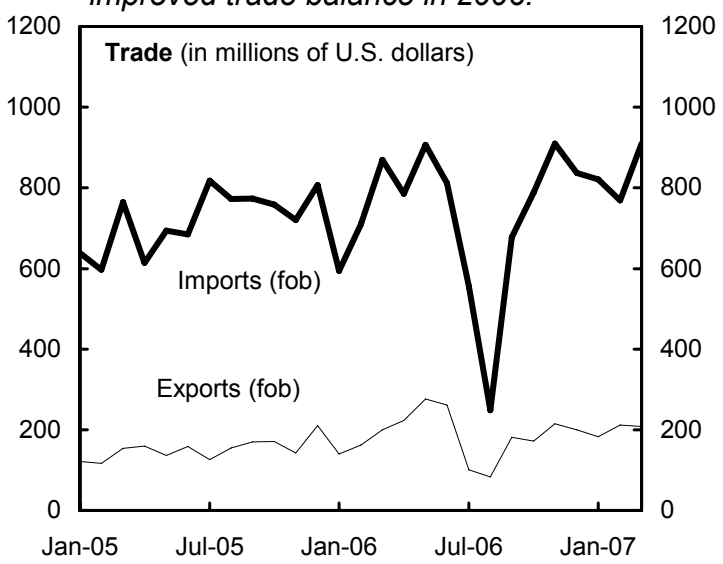

Deposit growth has slowed in light of the political stalemate.

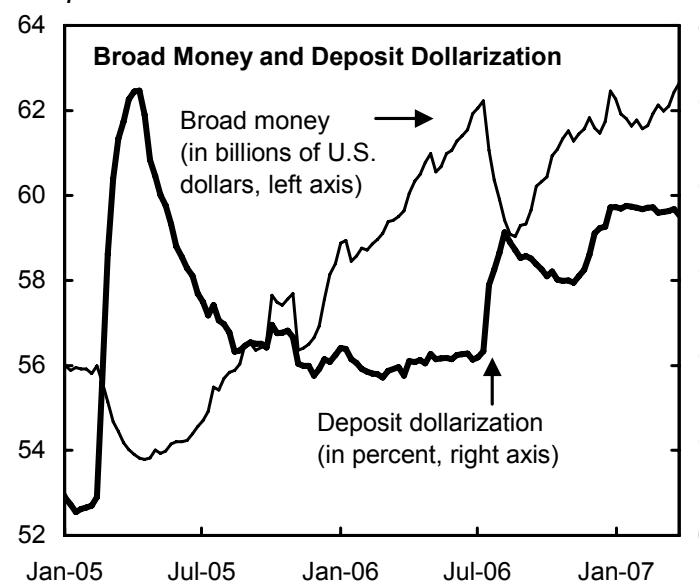

Inflation picked up during the 2006 conflict, but is receding again.

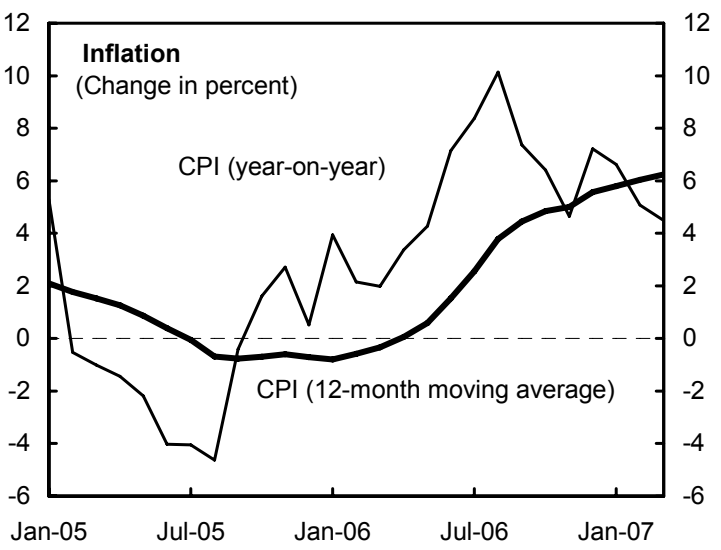

Gross reserves were buoyed by donor support during the conflict.

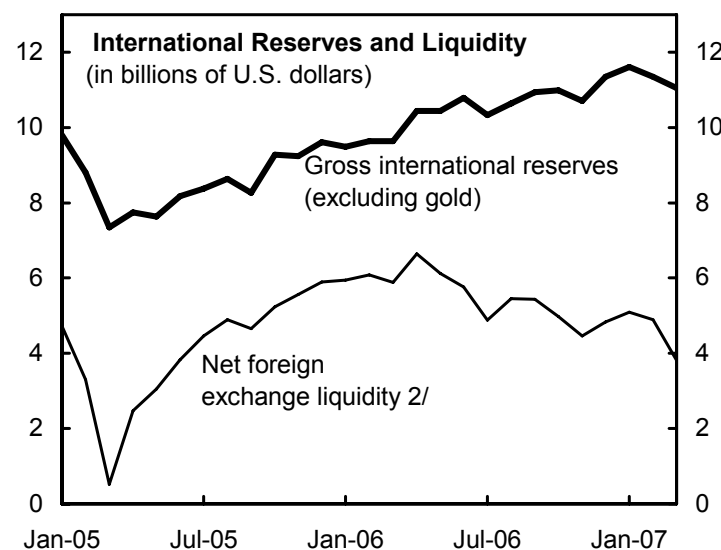

Spreads have not returned to pre-conflict lows.

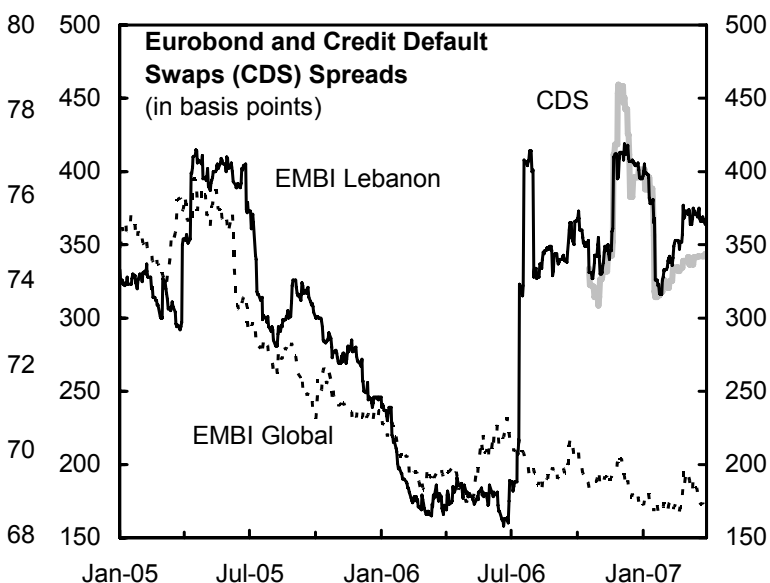

Source: Lebanese authorities; J.P. Morgan; Bloomberg; and Fund staff calculations.

$1 /$ Coincident indicator is a composite indicator of economic activity monitored by the central bank.

2/ Defined as gross international reserves minus principal and interest due over the next 12 months on all foreign currency liabilities of the central bank to entities other than the government of Lebanon. Excludes long-term foreign exchange liabilities of the central bank. 
6. The political tensions have also affected financial markets, though money demand remains robust. Notwithstanding considerable monthly volatility, bank deposits have grown at an average (annualized) rate of 9 percent between October 2006 and May 2007. ${ }^{3}$ Lebanese Eurobond and Credit Default Swap spreads remain some 200 basis points above the levels prevailing prior to the 2006 conflict, but have also been quite volatile reflecting political developments. Deposit dollarization (currently at 76 percent) is also higher than prior to the conflict, while the stock market index has remained broadly constant since end-2006 in very low trading.

\section{OUtLook AND Authorities' Views on Policies ${ }^{4}$}

\section{Discussions were based on a scenario developed by staff that incorporates full} implementation of the Paris III reform program (Text Table 2). Fiscal adjustment and privatization are expected to begin in 2008, and, as a result, government debt would be reduced by almost 50 percentage points to below 130 percent of GDP by 2012, in line with the authorities' targets. In addition to the contribution of fiscal adjustment ( 7 percentage points), the debt reduction comes from privatization (31 percentage points), the projected Paris III donors assistance (6 percentage points), and the transfer of unrealized gold valuation gains from the Banque du Liban (BdL) to the budget (7 percentage points). The associated improvement in confidence is assumed to result in a pick-up of growth to 4-5 percent a year (similar to the historical average rate over the last 15 years), and a narrowing of interest rate spreads. The authorities considered the macroeconomic scenario realistic, but believed that they will obtain a higher fiscal yield from their reforms.

\section{A. Minimizing Risks to the Paris III Reform Strategy}

\section{The Paris III reform strategy is subject to a number of risks, which were} acknowledged by the authorities. Given the large debt overhang and fiscal and external imbalances that are financed by short-term deposit inflows, Lebanon will remain vulnerable to shocks to confidence for years, even with full implementation of the reforms. The most immediate risk to the strategy is the political risk that reforms cannot be initiated or would be reversed. Shortfalls in growth or higher than projected real interest rates constitute the main macroeconomic risks. Lastly, there are some uncertainties over the yield of reforms, as well contingent liabilities that have yet to be quantified. The effects of these risks are illustrated by the debt sustainability analysis (Box 2).

\footnotetext{
${ }^{3}$ A temporary peak in deposits at end-2006 was reportedly related to some "window dressing" by banks aimed at posting high deposit growth rates for the year.

${ }^{4}$ Staff's views are given in Section IV.
} 
Text Table 2. Lebanon: The Paris III Fiscal Adjustment Objectives, 2006-12

\begin{tabular}{|c|c|c|c|c|}
\hline Measures & Timeline to Implementation & $\begin{array}{l}\text { Executive or } \\
\text { Legislative } \\
\text { Prerogative }\end{array}$ & $\begin{array}{l}\text { Cumulative } \\
\text { Yield in } \\
\text { Percent of } \\
\text { GDP (2006 to } \\
\text { 2008) }\end{array}$ & $\begin{array}{l}\text { Cumulative } \\
\text { Yield in } \\
\text { Percent of } \\
\text { GDP (2006 to } \\
\text { 2012) }\end{array}$ \\
\hline Revenue & & & 2.8 & 5.4 \\
\hline $\begin{array}{l}\text { Increase in the VAT rate (from } 10 \text { to } \\
12 \text {, and then to } 15 \text { percent) }\end{array}$ & $\begin{array}{l}\text { Rate to } 12 \text { percent is already in the } 2007 \\
\text { draft budget law with implementation on } \\
\text { January } 1,2008 \text {. Increase to } 15 \text { percent is } \\
\text { scheduled for } 2010 \text {. }\end{array}$ & Legislative & 1.1 & 2.5 \\
\hline Introduce a global income tax & $\begin{array}{l}\text { Law needs to be passed before end- } 2007 \\
\text { for the tax to be collected in } 2008 \text {. } \\
\text { Administrative reforms and taxpayer } \\
\text { information require significant lead time } \\
\text { between the passage of the law and the } \\
\text { implementation of the new tax regime. }\end{array}$ & Legislative & 0.0 & 1.0 \\
\hline $\begin{array}{l}\text { Increase in gasoline excises to their } \\
\text { pre-capping level }\end{array}$ & $\begin{array}{l}\text { Implementation is immediate following a } \\
\text { Council of Ministers decree. First increase } \\
\text { by September } 2007 \text {, thereafter annual until } \\
\text { pre-capping levels of } 2004 \text { have been re- } \\
\text { instated. }\end{array}$ & Executive & 0.8 & 1.1 \\
\hline $\begin{array}{l}\text { Increase in the rate of tax on interest } \\
\text { income (from } 5 \text { to } 7 \text { percent) }\end{array}$ & $\begin{array}{l}2007 \text { budget law with implementation on } \\
\text { January } 1,2008 \text {. }\end{array}$ & Legislative & 0.4 & 0.4 \\
\hline $\begin{array}{l}\text { Improved revenue from government } \\
\text { properties (Casino du Liban, etc.) }\end{array}$ & $\begin{array}{l}\text { Immediate. Negotiations have been } \\
\text { completed. }\end{array}$ & Executive & 0.4 & 0.4 \\
\hline $\begin{array}{l}\text { Improvement in property tax } \\
\text { administration and taxation of } \\
\text { seashore properties }\end{array}$ & Reforms are ongoing. & Executive & 0.2 & 0.2 \\
\hline Expenditure & & & 0.4 & 4.5 \\
\hline $\begin{array}{l}\text { Reforms leading to a nominal freeze of } \\
\text { the wage bill }\end{array}$ & Ongoing & Executive & 0.1 & 0.9 \\
\hline Reduction in EdL losses & $\begin{array}{l}\text { Reforms are ongoing. The World Bank is } \\
\text { actively involved. }\end{array}$ & Executive & 0.2 & 2.1 \\
\hline $\begin{array}{l}\text { Reduction in other current } \\
\text { expenditures (mostly transfers) }\end{array}$ & $\begin{array}{l}\text { Key measures include closing the Council } \\
\text { of the South and the Fund for the Displaced } \\
\text { (now scheduled for end-2009). }\end{array}$ & Executive & 0.6 & 1.9 \\
\hline $\begin{array}{l}\text { Increased capital spending (growth } \\
\text { enhancing) }\end{array}$ & $\begin{array}{l}\text { To be implemented each year within the } \\
\text { new budget law. }\end{array}$ & Legislative & -0.3 & -0.4 \\
\hline Adjustments & & & -2.4 & -5.9 \\
\hline Revenue loss due to privatization & Ongoing & Executive & -1.6 & -3.4 \\
\hline Change in grants & Ongoing & Executive & -0.4 & -3.0 \\
\hline Conflict-related expenditure & Ongoing & Executive & -0.5 & 1.0 \\
\hline Other $1 /$ & & & 0.0 & -0.6 \\
\hline $\begin{array}{l}\text { Change in primary fiscal balance } \\
\text { (including grants) }\end{array}$ & & & 0.9 & 3.9 \\
\hline
\end{tabular}

Sources: Lebanese authorities; and Fund staff.

$1 /$ Includes the fiscal impact of exogenous factors and one-off effects. 


\section{Box 2. Debt Sustainability Analysis}

The debt sustainability analysis (DSA) reveals that under a number of shocks, the debt-to-GDP ratio would revert to an unsustainable path. The DSA shows the impact of six shocks on the baseline debt trajectory as well as the implications of using historical values for the interest rate, growth rate, and the primary balance (Figure 2, and Table 11):

Panel 1: The baseline scenario-full implementation of the Paris III agenda.

Panel 2: A permanent increase in the real interest rate by 170 basis points (i.e., one-half standard deviation from its past distribution) relative to the baseline.

Panel 3: A drop in average GDP growth from 4 percent in the baseline to 3 percent, i.e., the average rate for 2002-06.

Panel 4: A shortfall in the yield from fiscal reforms, i.e. halving of the yield of the fiscal reform package. This reduces the average primary surplus to just over 1 percent of GDP in 2007-12, compared with over 4 percent of GDP in the baseline, and implies that the primary surplus converges to 1 percent of GDP in the long-run, compared with 3 percent of GDP in the baseline.

Panel 5: Absent sustained reforms, no privatization and only partial fiscal adjustment (the primary surplus reaches only 3 percent by 2012); growth remains sluggish at 3 percent per annum, while interest rate spreads widen by 220 basis points relative to the baseline.

Panel 6: No privatization - since privatization essentially brings forward the income stream from the privatized companies, the scenarios with and without privatization converge to the same debt-ratio in the long-run. However, this abstracts from the negative impact that abandoning privatization plans would have on growth and possibly interest rates relative to the Paris III scenario.

9. The authorities concurred with staff that broad domestic support was needed to achieve and sustain the targeted fiscal adjustment. They considered that the tranched donor support, which was conditional on reform implementation, would provide an effective incentive to maintain the reform momentum over time. Beyond that, they noted that the growth and social pillars of their Paris III program were intended to build public support for reforms by compensating for the inevitable difficulties of fiscal adjustment.

\section{The program's growth pillar is centered on privatization, improvements in the}

business climate, and opening of markets. The authorities emphasized that privatization of the telecom sector was the lynchpin of their growth strategy, and that additional public sector enterprises were also being slated for privatization. Furthermore, they were establishing a competitiveness council, consisting of private sector and government representatives that would be tasked with identifying legal and administrative impediments to growth. In this context, they were taking steps to streamline the process of obtaining business licenses, and, more generally, to lower the cost of doing business. The authorities also thought that accession to the World Trade Organization - envisaged for 2008 - would contribute to further liberalizing markets; they expected to have all relevant legislative changes ready for parliament by the end of 2007. 
Figure 2. Lebanon: Public Debt Sustainability, 2002-26

(Public debt in percent of GDP)

Panel 1: Baseline Scenario

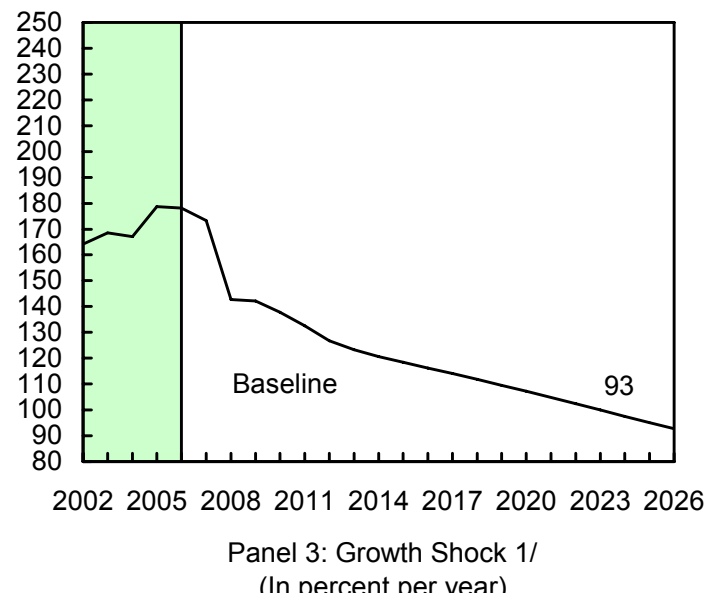

(In percent per year)

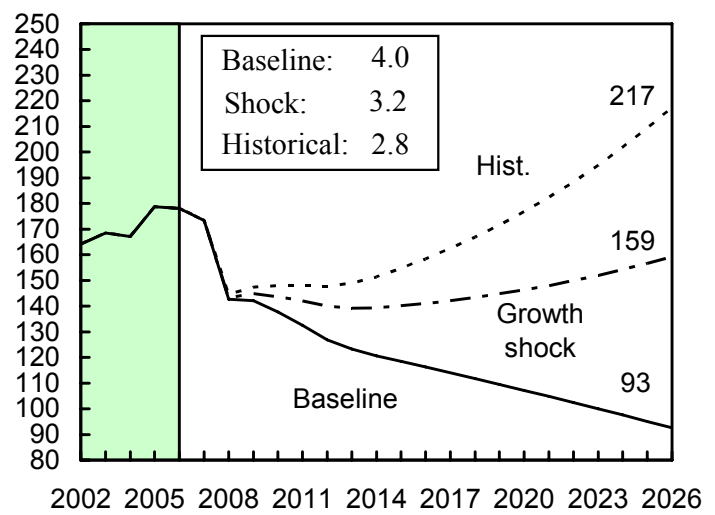

Panel 5: Lack of Consensus on Reforms 3/

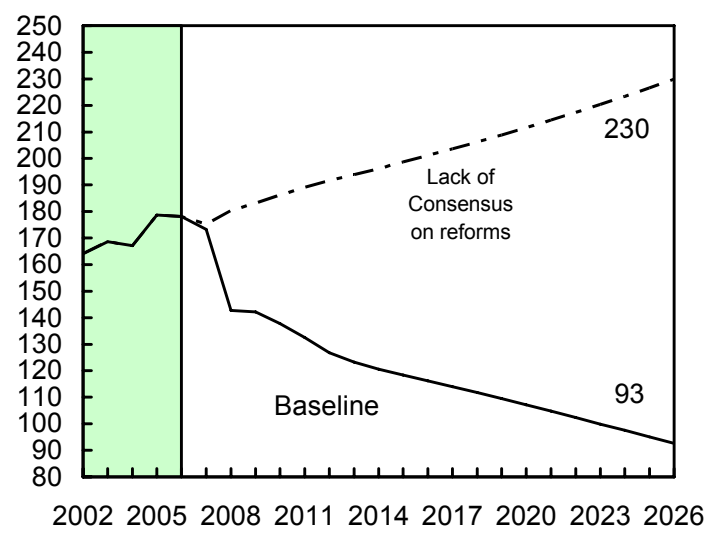

Panel 2: Real Interest Rate Shock 1/ (In percent)

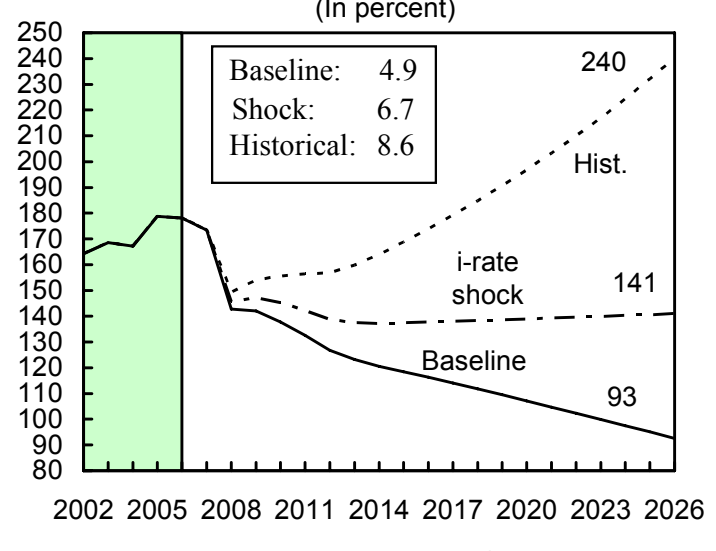

Panel 4: Primary Balance Shock $2 /$ (In percent of GDP)

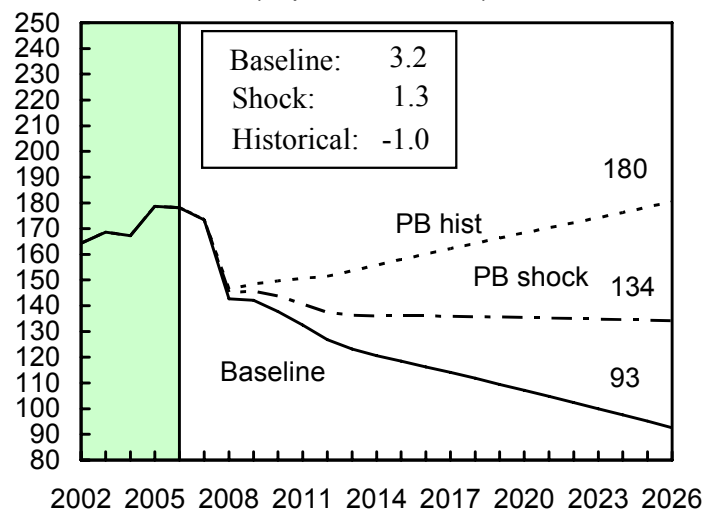

Panel 6: No Privatization, no growth impact 4/

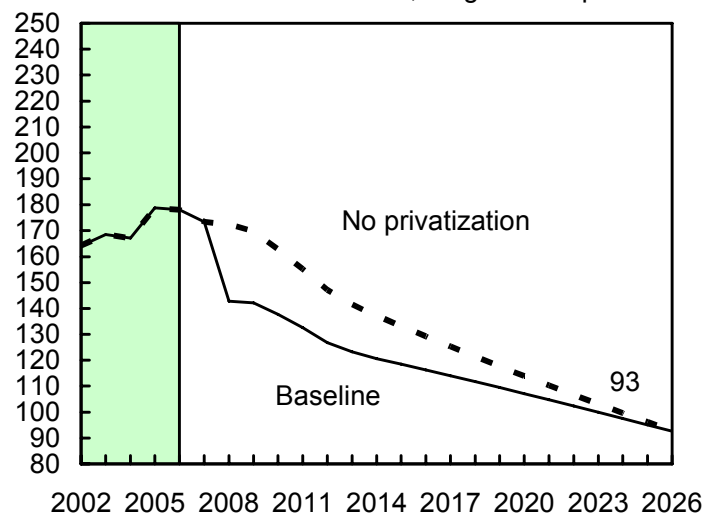

Sources: International Monetary Fund, country desk data, and staff estimates.

$1 /$ Growth shock based on average 2002-06 values. Interest rate shock is permanent one-half standard deviation shock. Figures in the boxes represent average projections for the respective variables in the baseline scenario and shock scenario; historical refers to 10 -year averages.

From 2012, the primary fiscal surplus reverts slowly to a long-term level of 3 percent of GDP.

2/ Through 2012, the planned revenue and expenditures reforms generate half of their estimated yield in the scenario; after 2012, the primary surplus slowly declines to 1 percent of GDP.

3 / Lack of consensus on reform prevents privatization and allows only partial fiscal adjustment.

4/ No privatization in the projected period. Assumes no adverse dynamic impact of no privatization. 
11. The main elements of the social pillar are to improve service delivery in health and education and strengthen the social safety nets. The authorities noted they could achieve a lot by redirecting the existing envelope of social spending, improving public services, and creating public social safety nets (including through a cash transfer system).

\section{The authorities were less concerned about uncertainties over the yield of} reforms, arguing that there was also an upside potential. For example, the ongoing revision of the reform plan for EdL was expected to lower reform costs, while yielding the same reduction in transfers from the budget. They also expected tax administration reforms to increase tax buoyancy relative to staff's revenue projections. However, the authorities acknowledged the risk of added spending pressures on account of the security situation.

\section{Reforms to address imbalances (and possible contingent liabilities) in the} pension and health system are being developed. The authorities did not see immediate pressures developing in the public pension system, and felt therefore that they had time to assess imbalances (ongoing) and introduce reforms. The reform of the private pension system - currently in parliament-envisions the system's transformation from an end-of-service allowance to a fully funded pension system. Transition costs may have to be borne by the state, but their extent would only be revealed once the audits of the National Social Security Fund's (NSSF's) accounts are completed (Table 12), and the contribution and replacement rates for the new system are finalized. In the meantime, the authorities plan to introduce professional asset management to raise the private pension systems' return on investment. Another source of open-ended budget transfers are the losses of the health fund of the NSSF. In this regard, the authorities are discussing with the World Bank options for addressing underlying structural problems in contribution rates and coverage, which, among other problems, create a bias toward hospitalization that is pushing up costs.

\section{In parallel, the authorities plan to develop institutions that will help sustain the} adjustment effort. They have taken steps to develop a medium-term budget framework to better align short-term policies with strategic objectives, and are also aiming to move gradually toward program budgeting. They also consider adopting a fiscal responsibility law to provide a self-reinforcing mechanism of fiscal adjustment and debt reduction that reduces the risk of backtracking. The authorities acknowledged that such institutional reforms will require substantial preparation.

\section{B. Monetary and Exchange Rate Policies}

\section{The authorities consider that their monetary policy framework has enabled} them to deal effectively with financial pressures. They believe that interest rate stability, notably in treasury bill (T-bill) rates, played a key role in maintaining confidence during periods of pressure (Table 13). However, they recognized that the counterpart to that was the need for the BdL to occasionally rely on alternative instruments (central bank CDs, special discount windows, swaps, etc.) to manage liquidity and safeguard international reserves. The 
authorities also reiterated that the BdL's mandate was to maintain financial stability, and that, in their view, this involved providing financing to the government in times of shortfalls from other sources. Nonetheless, they agreed that such financing should only be temporary, and that prolonged shortfalls in market demand would have to be met by raising T-bill rates.

16. The monetary authorities confirmed their intention to introduce new short-term instruments for managing liquidity once the financial situation improves. They considered a resolution of the political and security situation, and an improved fiscal environment as preconditions for moving toward short-term, market-based instruments of monetary control (such as repos and reverse repos). However, they acknowledged that this would require greater price flexibility in T-bill auctions. In the context of monitoring performance relative to the EPCA monetary and fiscal targets, the authorities are planning to establish a technical working group to enhance information sharing between the ministry of finance and the BdL.

\section{The authorities continue to regard the exchange rate peg as key to financial}

stability. Exchange rate stability was particularly important given balance sheet risks related to widespread dollarization and the government's high foreign currency debt servicing obligations. They agreed with staff that fiscal imbalances, but also temporary factors related to the post-conflict environment, were at the core of Lebanon's high current account deficit, and noted that the planned fiscal adjustment would help improve the current account position significantly. Against this background, and the fact that trade competitiveness was being maintained, the authorities concurred with the staff analysis (Box 3), which does not suggest that the exchange rate is misaligned. Furthermore, the authorities were confident that the envisaged structural reforms would generate the competitiveness gains needed to sustain growth.

\section{The authorities were confident that the weakening of the BdL's balance sheet}

has not impaired monetary control. They noted that the weakening was largely the result of managing past crises, although quasi-fiscal activities carried out by the BdL had also contributed. They did not see an immediate risk to their ability to control liquidity, and thought that the BdL's balance sheet could absorb the transfer to the government of unrealized gold valuation gains. Looking forward, the authorities expected that fiscal adjustment and improvements in confidence would help reduce dollarization, which would facilitate a further build-up of net international reserves and strengthen the BdL's income position. 


\section{Box 3. Assessment of the Level of the Real Exchange Rate}

Traditional indicators do not suggest that Lebanon has an external competitiveness problem.

- Largely reflecting the weakening of the U.S. dollar, the real effective exchange rate (REER) has depreciated 20 percent relative to its 2000-02 average, offsetting some competitiveness losses since the mid-1990s. The bilateral real exchange rate vis-à-vis the U.S. dollar- to which the Lebanese pound is pegged - has remained broadly stable over the past decade.

- Lebanese exports have remained competitive during difficult times. Merchandise exports grew at an Lebanon: CPI-Based Real Exchange Rate Developments (Index, 1995=100; January 1995-March 2007) average rate of 5 percent a year in volume terms in 2004-05 (staff estimate based on Lebanese customs data), and maintained positive momentum in 2006 ( 2 percent) and into 2007, despite the conflict-related disruptions in production and the two-month air, land, and sea blockade. As such, Lebanon's exports have more than kept pace with the buoyant demand in the region; the market shares vis-à-vis all trading partners have been stable in 2005-06. Exports of services (primarily but not exclusively tourism) have suffered from the political and security disruptions of 2005-07, but still have strong growth potential as was demonstrated in 2004.

Applying the three methodologies proposed by the IMF's Consultative Group on Exchange Rate Issues (CGER) does not suggest that the REER is misaligned.

- Equilibrium real exchange rate approach: An estimation of the long-run equilibrium REER derived from key macroeconomic fundamentals (the net external asset position (NEAP), the productivity differential with trading partners, terms of trade, and government consumption) suggests that the REER could actually be modestly undervalued relative to its estimated equilibrium level. However, the result is well within the margins of error in this type of analysis.

- External sustainability approach: In this approach, the underlying current account deficit in 2007 is compared to the current account deficit that would stabilize Lebanon's NEAP at the end of 2006. The empirical estimate of Lebanon's NEAP is subject to large uncertainty, and depending on the choice of the NEAP, the REER is either slightly undervalued or slightly overvalued, also within the typical margin of error.

- Macroeconomic balance approach: For this approach, a current account norm of -5 to -6 percent of GDP is derived based on macroeconomic fundamentals (fiscal balance, dependency ratio, population growth, NEAP, oil balance, output growth, income relative to the United States in purchasing power parity terms). The current account norm is then compared to medium-term projections based on the authorities' planned policies under the Paris III program. With full implementation of the authorities' program, the projected current account deficit for 2012 would narrow to $-5 \frac{1}{2}$ percent of GDP. However, if the fiscal adjustment planned under the Paris III program is not achieved in full, the projected current account deficit under current policies would exceed the norm which could potentially lead to external instability. This result is also reflected in the historical scenarios of the DSA (Figure 2) that show an unsustainable debt path if the program is not implemented and the key macroeconomic variables remain at their average levels over the last decade. 


\section{The BdL has introduced a scheme to provide relief to banks and businesses}

affected by the 2006 conflict. Under the scheme, the BdL would provide loans to banks at below-market interest rates which the banks would re-invest in fresh T-bills. Banks would then use the interest differential to provide a 60 percent subsidy toward the reconstruction of productive facilities destroyed during the conflict. The authorities argued that in the absence of any assistance, some banks with large exposures would find it difficult to absorb conflict-related losses. The authorities estimated the total subsidy under the scheme would be at most $\$ 180$ million, although disbursements could be significantly lower owing to strict eligibility requirements.

\section{Banking Sector Vulnerabilities}

\section{The banking sector is profitable and its capitalization is increasing, though} vulnerabilities remain high (Tables 14-15). The balance sheet of domestic banks stands at $\$ 77$ billion (320 percent of GDP) and exposure to the sovereign (government and central bank) is around 50 percent of assets. The authorities were concerned about the substantial maturity mismatch that banks carry on their books, largely from sourcing their holdings of government paper from short-term deposits (Table 16). In addition, the high degree of dollarization exposes banks to substantial credit risk. Reducing these vulnerabilities will ultimately depend on the success of the debt reduction strategy, although the authorities are working in parallel to encourage banks to strengthen risk management and diversify their portfolio. While some banks are targeting a reduction in their sovereign exposure, their systemic exposure to the government makes it difficult for them as a group not to roll over government paper. The authorities took some comfort in the fact that banking sector profitability increased in 2006 and early 2007, although this was in part the reflection of regulatory measures to ease provisioning rules in the wake of the conflict.

\section{The authorities welcomed the regional diversification strategy of commercial}

banks. The larger banks are expanding very rapidly their presence in countries where their expertise puts them at a strong comparative advantage by setting up local subsidiaries and branches, and potentially by cross-border lending. ${ }^{5}$ They are also developing domestic private sector lending, in particular retail lending. Among the larger banks, 20 percent of assets are by now in foreign operations, with the objective of generating half of their profits abroad within three years. The banking control commission has taken steps to facilitate and enhance its monitoring of the banks' diversification strategy. Thus, for instance, in 2006 it issued a circular raising the limits on the exposure of Lebanese banks to non-resident borrowers, and has signed, or is negotiating, memoranda of understanding on consolidated supervision with supervisory authorities in countries where Lebanese banks are expanding.

\footnotetext{
${ }^{5}$ In addition to their traditional bases in Europe and Cyprus, Lebanese banks are (or plan to be) present in Algeria, Egypt, Iraq, Jordan, Nigeria, Oman, Qatar, Sudan, Syria, Tunisia, and the United Arab Emirates.
} 


\section{The authorities expect commercial banks to strengthen risk management in} response to the introduction of Basel II standards in 2008. The banking system seems well-prepared for the introduction of Basel II, and the authorities expect all banks to meet the tightened capital adequacy criteria. The increased risk weight on foreign currency denominated government and BdL debt instruments would force banks to internalize in part the systemic risks associated with sovereign foreign currency debt. ${ }^{6}$ The authorities are also trying to encourage banks to better manage their maturity mismatch. To that end, they decided, for the time being, not to reopen the repo window for Lebanese lira T-bills which they had closed during last year's conflict to ease pressures on the Lebanese lira.

\section{The authorities saw scope for consolidation of the banking sector over the} medium term. In particular, smaller banks whose main source of income is lending to the government may lose ground to larger banks which are better positioned to adapt to Basel II and diversify their asset structure. The promotion of mergers, including through financial incentives provided by the BdL, has been the main instrument to facilitate the exit of non-viable banks in the past. The BdL believes this is the most suitable instrument in the Lebanese context, because of concerns that outright bank failures would destabilize the system. However, this instrument could give rise to moral hazard, notably in terms of depositor, shareholder, and management behavior.

\section{Policies for 2007 and 2008}

\section{Political tensions and outbreaks of violence are key obstacles to reform} implementation and economic recovery. The political stalemate is constraining the government's room for maneuver and paralyzing legislative activity. This, combined with security concerns, is expected to weigh negatively on economic activity. As such, real GDP growth is projected at about 2 percent in 2007. Under the fixed exchange rate regime, CPI inflation should return to around 2 percent by year-end. Capital (including deposit) inflows are subject to a high degree of uncertainty and are therefore projected conservativelymoney growth is put at 5 percent for the year as a whole. Reflecting reconstruction expenditure and replenishment of inventories, the current account deficit is expected to increase to 11 percent of GDP in 2007, largely financed by official inflows and foreign direct investment.

\section{The authorities expected to be able to contain the primary fiscal deficit} (excluding grants) to 3.7 percent of GDP in 2007 as programmed. First-quarter performance was within program targets (Box 4). However, the authorities recognized the

\footnotetext{
${ }^{6}$ The risk weight on Eurobonds would increase from 20-50 percent presently to 100 percent, and that on central bank foreign currency debt from zero to 100 percent. The risk weight on domestic currency sovereign debt is expected to remain at zero.
} 
risks of unforeseen expenditure pressures, such as from security measures and transfers to EdL on account of higher oil prices. They indicated that, as in 2006, they would maintain tight expenditure control—-delaying low-priority spending until later in the year - to build up a buffer in the event of unforeseen shocks. On the revenue front, the widening gap between domestic and international oil prices reduced the gasoline excise to near zero in May. On current trends, gasoline excise revenues would fall short of program targets by around $1 / 2$ percent of GDP for the year. However, the authorities were confident that, if the political situation stabilized, they could introduce a floor on excises (of $\$ 0.20$ per liter) by September 2007, as agreed under the program, which is expected to yield $1 / 2$ percent of GDP during the remainder of 2007. At the same time, they noted that other revenues have been more buoyant than expected.

\section{Box 4. Performance Under the Program Supported by $\mathrm{EPCA}^{1}$}

The authorities met all end-March 2007 quantitative targets under EPCA, except for the ceiling on government borrowing from the BdL, which was exceeded by a small margin (Table 17). Stronger than projected revenue collection helped contain the primary deficit and the accumulation of net debt in the first quarter. However, insufficient demand for government paper by commercial banks led the government to rely more on BdL financing than programmed. The outcome was LL 106 billion (\$70 million) above the LL 903 billion (\$602 million) flow envisaged for the first quarter. Despite the difficult market situation, the gross reserves target was met with a modest margin. No domestic or external arrears were accumulated.

The authorities also reported on progress toward achieving the monitorable actions for end-June (Table 18). On May 21, the cabinet approved the draft budget for 2007, which includes the foreign financed component of the Council of Development and Reconstruction and activities of the Higher Relief Council. The auditing of EdL has already started, and the launching of the audit of NSSF is on track. With respect to privatization, the authorities have modified their strategy to privatize only the licenses of the two mobile phone companies and effect the transfer of assets and contracts through separate transactions. This would avoid the need for a special law prior to privatization, and ensure that privatization can proceed as planned, making the end-June submission of such a law to parliament no longer relevant.

${ }^{1}$ IMF Staff Country Report No. 07/177. 


\section{The authorities were confident that they could meet their financing needs through donor support and from the market during the remainder of 2007 . They} pointed to recent T-bill auctions and a Eurobond issue in May as indications that commercial banks had returned to the market, and, therefore, saw no immediate need for raising T-bill rates. At the same time, negotiations with key donors are proceeding, and disbursements of grants and loans could amount to $\$ 1.9$ billion in 2007 (Text Table 3). As such, the authorities were confident that they would reduce net borrowing from the BdL and achieve the programmed build-up of international reserves over the rest of 2007 (Tables 19-20). As another risk to their financing strategy, they listed EdL's fuel payments over which they had only limited control. Negotiations with domestic banks on a possible Paris III contribution have not progressed, with banks being reluctant to make commitments before reform implementation is underway.

Text Table 3. Lebanon: Paris III Aid

(In millions of U.S. dollars, unless otherwise specified)

\begin{tabular}{|c|c|c|c|c|c|c|c|c|}
\hline & \multirow{3}{*}{$\begin{array}{c}\text { Total } \\
\text { Pledges }\end{array}$} & \multicolumn{7}{|c|}{ New Grants and Loans to Government } \\
\hline & & \multicolumn{3}{|c|}{ Paris III Pledges } & \multicolumn{2}{|c|}{ Rev. Proj. for $2007-101 /$} & \multicolumn{2}{|c|}{2007} \\
\hline & & Total & $\begin{array}{l}\text { Budget } \\
\text { Support }\end{array}$ & $\begin{array}{c}\text { Project } \\
\text { Assistance }\end{array}$ & Total & $\begin{array}{c}\text { Grant } \\
\text { Element 2/ } \\
\text { (Estimate, in } \\
\text { percent) }\end{array}$ & Rev. Proj. & $\begin{array}{l}\text { Received } \\
\text { Jan-May }\end{array}$ \\
\hline Total & 7,565 & 5,018 & 2,327 & 2,691 & 3,083 & 51.5 & 1,888 & 100 \\
\hline Multilateral & 3,978 & 2,213 & 835 & 1,378 & 738 & 37.7 & 306 & 0 \\
\hline Bilateral & 3,587 & 2,805 & 1,492 & 1,313 & 2,346 & 55.9 & 1,583 & 100 \\
\hline
\end{tabular}

Sources: Lebanese authorities, and Fund staff estimates.

1/ Projection assumes partial conversion of project assistance pledges to budget support, and non-acceptance of a majority of remaining project assistance, particularly project loans.

2/ Discounting debt service projections at Lebanon's average projected interest rate for market financing in U.S. dollars (7.45 percent).

27. The authorities reported on recent steps toward fiscal adjustment in 2008. On the revenue side, the draft 2007 budget already provides for increasing the value-added tax rate and the tax on interest income as of 2008. Preparations for the introduction of a global income tax in 2008 were advancing, with a view to submitting the draft law to parliament in 2007. The authorities also expected ongoing revenue administration reforms, such as the introduction of a medium taxpayer office, new audit procedures, and changes to the property valuation system, to yield revenue gains. On the expenditure side, they were finalizing the reform plans for EdL (Box 5) and NSSF, and were developing a reform plan for the health sector, all in cooperation with the World Bank. With respect to EdL, they were more optimistic than staff about the potential yield of reforms. ${ }^{7}$ Moreover, they were aiming for an

\footnotetext{
${ }^{7}$ Staff's scenario envisages that net transfers to EdL (excluding debt service, but including investment costs) would decline to 1.3 percent of GDP by 2012, from 3.3 percent of GDP in 2006 .
} 
across-the-board cut in discretionary spending of five percent in 2008, and a reduction of expenditure duplication across ministries through better cooperation and information sharing. They also pointed to the planned establishment of a debt management office charged with reducing debt service costs and improving asset management, although details remain to be worked out.

\section{Box 5. Energy Sector Reforms}

Electricity production in Lebanon comes at a high budgetary cost, while service delivery is of poor quality. Budget transfers to EdL net of debt service amounted to $\$ 750$ million (3.3 percent of GDP) in 2006. Weak management, poor governance, inadequate infrastructure, and reliance on oil instead of less expensive gas are the sector's main problems. Technical losses are estimated at 15 percent of production, while non-technical losses (essentially illegal connections) account for another 18 percent. At the same time, power cuts are endemic.

The government is finalizing a comprehensive energy sector reform plan in close cooperation with the World Bank. EdL's financial management will be enhanced through: corporatization (which would allow hiring a more professional work force); the appointment of a new board of directors and qualified advisors; auditing of EdL's accounts; and installing remote meters. Reforms also seek to promote private sector involvement and increase capacity through independent power producers; tendering is envisaged for early 2008. Fuel costs are to be reduced by switching to natural gas in at least one power plant in the second quarter of 2008; this plant might also be privatized alongside the entry of independent power producers. A National Control Center, planned for 2008, is expected to realize efficiency gains in distribution. Toward the end of the reform period, the authorities plan to unbundle and partially privatize the sector. A regulator would be set up in parallel.

The tariff structure is far from achieving cost recovery and suffers from inefficiencies. Given the high production costs and losses, the average tariff of 9.4 cents $/ \mathrm{kWh}$ achieves cost recovery at a fuel price of $\$ 25 / \mathrm{barrel}$. The above reforms would narrow the gap relative to current oil prices, but an increase in tariffs may also be required, although international experience suggests that tariff increases should be introduced following improvements in service quality to avoid even higher non-payment and illegal connections. At the same time, Lebanon's tariff is already significantly higher than regional tariffs which puts Lebanese producers at a disadvantage. In addition, there are inefficiencies in the tariff structure, for example, the peak tariff for industry encourages self generation.

\section{The authorities also emphasized ongoing efforts toward strengthening public}

financial management. The carryover of committed and uncommitted spending from one budget year to the next has seriously weakened the ability to control budgetary outcomes and to align spending to current priorities. To address this problem, the authorities intend to roll-back the carry-over of committed spending starting in the 2008 budget. As a first step, they plan to explicitly revoke the ability of line ministries to carryover uncommitted 
expenditures beyond one month into the new budget year in the 2007 budget. The authorities explained that the 2008 budget circular also introduces the notion of medium-term planning and top-down spending envelopes for line ministries. In particular, they would pilot medium-term budgeting that incorporates the implications of investment spending for future current spending in four ministries and agencies.

\section{E. Other Issues}

29. The authorities are working on improving the statistical system, but significant data problems remain. With support from INSEE, they are revising the national accounts, including the compilation of quarterly GDP data. The 2004 National Accounts have just been released. However, statistical provision in other areas (balance of payments, prices, employment, wage and social indicators) remains seriously deficient. Lebanon is due to be assessed by the Middle East North Africa Financial Action Task Force in January 2008.

\section{StAFF APPRAisal}

30. The authorities' reform strategy lays out a promising path toward reducing Lebanon's large debt overhang and financial vulnerabilities. The authorities' medium-term fiscal adjustment objectives are appropriately ambitious in the circumstances. The reform measures are designed to yield the targeted improvement in the primary balance, and, combined with pledged donor support and privatization, should reduce the debt-to-GDP ratio significantly over the next five years. The challenge now is to move from the planning stage to implementation, which would be facilitated by improvements in the political and security situation.

31. Performance in the first quarter of $\mathbf{2 0 0 7}$ bodes well for the attainment of the program objectives for the year, but the uncertain economic and financial environment requires close monitoring. The authorities' intention to create a buffer by maintaining strict expenditure discipline is welcome. At the same time, gasoline excise revenues should be safeguarded by promptly raising gasoline prices in line with recent increases in international oil prices. The authorities' commitment to reduce reliance on central bank financing over the remainder of the year is equally welcome. Every effort should be made to limit any new borrowing from the BdL to short-term bridge financing in order to safeguard international reserves. To that end, greater interest rate flexibility is necessary.

\section{This transition year is the time to prepare the ground for sizeable adjustment}

and deep-seated reforms starting in 2008. The decision to include in the draft 2007 budget law the 2008 increase in the value-added tax and the tax on interest income provides a strong positive signal in this direction. The authorities are also encouraged to ensure that all legislative and administrative work for the introduction of the GIT in 2008 is completed before the end of 2007. The largest source of adjustment on the expenditure side over the medium term is to come from structural reforms of the energy and social sectors, which have 
been a source of large fiscal leakages over the years. Completion of these reform plans and their swift implementation are therefore key priorities for 2007-08. The success of energy sector reforms will require a careful sequencing of infrastructural and governance initiatives to avoid compounding existing problems, and NSSF reforms should be guided by fiscal considerations.

\section{Significant improvements in public financial management are necessary to strengthen budgetary control, improve the allocation of scarce resources to priority} areas, and enhance the effectiveness of policies. Staff encourages the authorities to follow-up on the action plan developed with Fund technical assistance to improve cash and budget management functions. At the same time, across-the-board expenditure cuts should, in general, be avoided because they are hard to sustain and undermine the quality of public spending. More generally, comprehensive public financial management reforms would be a prerequisite for the envisaged adoption of a fiscal responsibility law.

\section{Fiscal adjustment will facilitate the reform of the monetary policy framework.} Once more stable and predictable market conditions prevail, the central bank should be able to focus on guiding interest rates through transparent short-term instruments, which would allow the BdL to achieve its balance of payments and monetary objectives more efficiently. This will need to be accompanied by price flexibility in T-bill auctions. Such an environment would create the conditions for the government securities market to develop, thereby attracting a wider range of investors and helping the government diversify its financing base. As a first step, the authorities could consider reopening the repo window and relying on the repo rate to influence banks' behavior. In the short term, the interlinkages between the government's cash and debt management and the BdL's liquidity and reserve management call for close cooperation between the two institutions to increase the efficiency of financial policies. Steps being taken in this direction are welcome.

35. Progress is also needed on strengthening the central bank's balance sheet to preserve the monetary authority's ability to control liquidity over the medium term. An improvement in the overall financial situation and de-dollarization will help in this regard. However, financing operations, such as the transfer of unrealized gold valuation gains to the budget, and quasi-fiscal activities, such as providing subsidized lending to banks, adversely impact on the BdL's income and balance sheet positions and should therefore be avoided. More generally, public support to the private sector should be provided through the budget to ensure consistency with policy priorities. The privatization of the assets held by the BdL would also strengthen its financial position, while contributing to the government's growth agenda.

36. The exchange rate peg to the U.S. dollar has contributed significantly to maintaining financial stability under very difficult circumstances and without impairing competitiveness. The peg played an important role as a nominal anchor during recent financial pressures. In the current circumstances, international reserves held by the 
BdL combined with the banking system's liquidity cushion appear sufficient to meet temporary pressures on the exchange rate, and the REER appears broadly in line with fundamentals. Going forward, macroeconomic policies need to be geared toward supporting the exchange rate peg. The debt overhang and the large external current account deficits are the counterpart of fiscal imbalances and, therefore, should be addressed by implementing the authorities' Paris III fiscal adjustment program.

\section{Domestic banks remain the primary source for the government's financing}

needs. The resulting interdependence of the government, the central bank, and the commercial banks has created incentives for all actors to behave in a concerted way to preserve financial stability. However, this interdependence also creates systemic risks, in that shocks to either the fiscal or the financial sector would be quickly passed on to other sectors. In this regard, the commercial banks' strategy of regional expansion and focus on private sector lending is welcome both from a risk management perspective, and given the envisaged decline in government financing needs over the medium term. The authorities have been aptly accompanying this process through regulatory and supervisory reforms, and it is important that they deepen these efforts as banks expand into new cross-border activities, including by implementing the applicable Basel Core Principles. Moreover, there is a need to strengthen the bank resolution mechanism to facilitate consolidation when needed, while minimizing moral hazard and increasing banks' management accountability and shareholder responsibility.

\section{The authorities' program appropriately emphasizes private sector growth and} improved delivery of social services. Privatization of the telecom sector is a crucial element of the growth strategy and should be accompanied by endowing the regulatory authority with the powers and capacity to ensure proper competition in the sector. Staff also welcomes the authorities' intention to widen the privatization agenda to other sectors, as well as ongoing efforts to improve the business climate. In this regard, the growth agenda should be complemented by actions to dismantle oligopolistic practices and eliminate barriers to entry and exit.

\section{Timely and flexible disbursement of Paris III pledges is another important} element for the success of the authorities' strategy. Progress has been made in locking in the terms and conditions for the release of funds from some key donors, but negotiations are still underway with others. Staff fully supports the authorities' request that donors make timely disbursements and convert their pledges from project to budget support, or at least align their project disbursements to the government's own spending priorities.

\section{Risks to the reform strategy call for a continuous reassessment of policies.}

Shocks to the macroeconomic environment, shortfalls in the privatization program, and contingent fiscal liabilities (from actuarial imbalances in the public and private pension systems, open-ended transfers to the health fund, and unforeseen costs from power sector reform) all have the potential to throw the economy off course relative to the targeted debt 
reduction path, and to require corrective actions. Equally important are implementation risks, particularly in view of domestic and regional tensions and the need to maintain consensus around the reform program. The authorities' emphasis on a multipillar approach of fiscal adjustment, growth promotion, and improved social services should help mitigate these risks. In addition, a wider public debate about the economic and financial challenges facing Lebanon would be important to sustain public and political support for reform and adjustment during and beyond the Paris III horizon.

41. Data gaps hamper the analysis of real and external sector developments. High level commitment is needed to address these shortcomings through a comprehensive strategy to strengthen the statistical system.

42. It is proposed that the next Article IV consultation will be held on the standard 12-month cycle. Quarterly reports on performance under the program supported by EPCA will be issued for the information of Executive Directors, as requested by Directors at the time of the EPCA approval. 
Table 1. Lebanon: Selected Economic Indicators, 2003-12

\begin{tabular}{|c|c|c|c|c|c|c|c|c|c|c|}
\hline & $\begin{array}{c}2003 \\
\text { Act. }\end{array}$ & $\begin{array}{r}2004 \\
\text { Act. }\end{array}$ & $\begin{array}{c}2005 \\
\text { Act. }\end{array}$ & $\begin{array}{r}2006 \\
\text { Prel. Act. }\end{array}$ & $\begin{array}{l}2007 \\
\text { Proj. }\end{array}$ & $\begin{array}{l}2008 \\
\text { Proj. }\end{array}$ & $\begin{array}{l}2009 \\
\text { Proj. }\end{array}$ & $\begin{array}{l}2010 \\
\text { Proj. }\end{array}$ & $\begin{array}{l}2011 \\
\text { Proj. }\end{array}$ & $\begin{array}{l}2012 \\
\text { Proj. }\end{array}$ \\
\hline Output and prices & \multicolumn{10}{|c|}{ (Annual percentage change) } \\
\hline Real GDP (market price) & 4.1 & 7.4 & 1.0 & 0.0 & 2.0 & 3.5 & 4.5 & 5.0 & 5.0 & 5.0 \\
\hline Consumer prices (end-of- period) & 2.2 & 2.0 & 0.5 & 7.2 & 2.0 & 3.0 & 2.0 & 3.5 & 2.0 & 2.0 \\
\hline Consumer prices (period average) & 1.3 & 1.7 & -0.7 & 5.6 & 3.5 & 2.5 & 2.5 & 2.8 & 2.8 & 2.0 \\
\hline Investment and saving & \multicolumn{10}{|c|}{ (In percent of GDP) } \\
\hline Gross capital formation & 19.3 & 22.0 & 17.0 & 11.4 & 17.6 & 17.1 & 18.7 & 20.1 & 21.3 & 21.4 \\
\hline Government & 3.1 & 3.3 & 2.2 & 2.5 & 4.9 & 3.0 & 2.8 & 2.9 & 2.9 & 2.9 \\
\hline Nongovernment & 16.2 & 18.8 & 14.8 & 8.9 & 12.7 & 14.1 & 15.9 & 17.2 & 18.4 & 18.5 \\
\hline Gross national savings & 6.1 & 6.5 & 3.4 & 5.2 & 7.0 & 7.7 & 9.2 & 12.1 & 15.5 & 15.9 \\
\hline Government & -10.2 & -5.4 & -6.3 & -8.6 & -7.3 & -6.1 & -5.3 & -2.1 & -0.8 & -0.1 \\
\hline Nongovernment & 16.3 & 11.9 & 9.6 & 13.8 & 14.3 & 13.8 & 14.5 & 14.2 & 16.4 & 15.9 \\
\hline Public finances & \multicolumn{10}{|c|}{ (In percent of GDP) } \\
\hline Revenue (including grants) & 22.1 & 23.1 & 22.8 & 24.8 & 26.5 & 25.9 & 22.0 & 23.2 & 23.4 & 23.3 \\
\hline Expenditure & 35.4 & 31.8 & 31.2 & 35.9 & 38.7 & 35.1 & 30.1 & 28.2 & 27.1 & 26.3 \\
\hline Budget balance (including grants) & -13.3 & -8.6 & -8.4 & -11.1 & -12.2 & -9.1 & -8.1 & -5.0 & -3.8 & -3.0 \\
\hline Primary balance (including grants) & 3.3 & 3.5 & 2.1 & 1.7 & 0.1 & 2.6 & 1.8 & 4.4 & 5.2 & 5.6 \\
\hline Total government debt & 169 & 167 & 179 & 178 & 173 & 143 & 142 & 138 & 133 & 127 \\
\hline Monetary sector & \multicolumn{10}{|c|}{ (Annual percentage change, unless otherwise indicated) } \\
\hline Credit to the private sector & 0.3 & 5.2 & 1.9 & 6.0 & 6.3 & 24.0 & 6.0 & 6.0 & 6.0 & 6.0 \\
\hline Base money & 12.3 & 10.3 & 4.7 & 8.2 & 5.9 & 5.1 & 5.1 & 5.1 & 5.1 & 5.0 \\
\hline Broad money $1 /$ & 15.5 & 12.3 & 3.5 & 6.4 & 5.0 & 5.0 & 5.0 & 5.0 & 5.0 & 5.0 \\
\hline Velocity of broad money (level) & 0.4 & 0.4 & 0.4 & 0.4 & 0.4 & 0.4 & 0.4 & 0.4 & 0.4 & 0.4 \\
\hline \multicolumn{11}{|l|}{ Interest rates (period average, in percent) } \\
\hline Three-month treasury bill rate & 6.7 & 5.2 & 5.2 & 5.2 & $\ldots$ & $\ldots$ & $\ldots$ & $\ldots$ & $\ldots$ & $\ldots$ \\
\hline Two-year treasury bill rate & 8.0 & 7.9 & 8.5 & 8.7 & 8.7 & 8.5 & 8.2 & 7.8 & 7.6 & 7.4 \\
\hline External sector & \multicolumn{10}{|c|}{ (In percent of GDP, unless otherwise indicated) } \\
\hline Exports of goods (in US\$, percentage change) & 43.2 & 18.3 & 11.1 & 22.5 & 14.8 & 13.2 & 11.8 & 11.8 & 11.6 & 10.3 \\
\hline Imports of goods (in US\$, percentage change) & 10.4 & 30.3 & -1.2 & 1.8 & 17.3 & 7.4 & 6.0 & 5.9 & 5.1 & 8.7 \\
\hline Merchandise trade balance & -24.2 & -30.1 & -28.4 & -25.3 & -28.4 & -28.2 & -27.3 & -26.1 & -24.7 & -24.8 \\
\hline Current account excluding official transfers & -13.9 & -16.0 & -14.2 & -7.4 & -13.0 & -12.0 & -10.5 & -8.5 & -6.3 & -5.9 \\
\hline Current account including official transfers & -13.2 & -15.5 & -13.6 & -6.2 & -10.6 & -9.4 & -9.4 & -8.0 & -5.8 & -5.5 \\
\hline Foreign direct investment & 8.7 & 10.9 & 12.2 & 12.0 & 9.6 & 24.7 & 9.1 & 8.9 & 8.7 & 8.5 \\
\hline Total external debt & 175 & 187 & 190 & 198 & 195 & 186 & 176 & 168 & 161 & 152 \\
\hline Gross reserves (in millions of U.S. dollars) & 10,271 & 9,575 & 9,611 & 11,353 & 11,121 & 12,347 & 10,920 & 10,963 & 11,574 & 11,897 \\
\hline In months of next year imports of goods and services & 8.1 & 7.7 & 7.2 & 7.6 & 6.9 & 7.2 & 6.0 & 5.7 & 5.5 & 5.7 \\
\hline In percent of short-term external debt $2 /$ & 35.6 & 27.1 & 28.5 & 32.1 & 31.0 & 34.0 & 29.9 & 29.1 & 29.5 & 30.8 \\
\hline In percent of banking system foreign currency deposits & 40.3 & 31.9 & 29.0 & 30.1 & 27.9 & 29.9 & 26.0 & 24.9 & 25.5 & 25.4 \\
\hline In percent of total banking system deposits & 24.8 & 21.0 & 20.1 & 21.9 & 20.3 & 21.5 & 18.1 & 17.3 & 17.4 & 17.0 \\
\hline \multicolumn{11}{|l|}{ Memorandum items: } \\
\hline Nominal GDP (in billions of U.S. dollars) & 19.8 & 21.5 & 21.5 & 22.7 & 24.0 & 25.3 & 27.0 & 28.9 & 31.0 & 33.2 \\
\hline Net imports of petroleum products (in millions of U.S. dollars', & $-1,057$ & $-1,833$ & $-2,082$ & $-2,172$ & $-2,094$ & $-2,310$ & $-2,404$ & $-2,515$ & $-2,620$ & $-2,729$ \\
\hline Local currency per U.S. dollar (period average) & 1,508 & 1,508 & 1,508 & 1,508 & $\ldots$ & $\ldots$ & $\ldots$ & $\ldots$ & $\ldots$ & $\ldots$ \\
\hline \multicolumn{11}{|l|}{ Real effective exchange rate change) } \\
\hline (annual average, percent change) & -10.7 & -6.8 & -4.1 & 2.2 & $\ldots$ & $\ldots$ & $\ldots$ & $\ldots$ & $\ldots$ & $\ldots$ \\
\hline Stock market index & 457 & 637 & 1,309 & 1,184 & $\ldots$ & $\ldots$ & $\ldots$ & $\ldots$ & $\ldots$ & $\ldots$ \\
\hline
\end{tabular}

Sources: Lebanese authorities; and Fund staff estimates.

$1 /$ Defined as cash in circulation plus resident and non-resident deposits.

2/ Short-term debt on a remaining maturity basis. 
Table 2. Lebanon: Central Government Primary Balance, 2003-08

(In billions of Lebanese pounds)

\begin{tabular}{|c|c|c|c|c|c|c|c|c|c|}
\hline & & & & & & 20 & & & \\
\hline & 2003 & 2004 & 2005 & 2006 & Q1 & & Year & & 2008 \\
\hline & $\begin{array}{l}\text { Year } \\
\text { Act. }\end{array}$ & $\begin{array}{l}\text { Year } \\
\text { Act. }\end{array}$ & $\begin{array}{l}\text { Year } \\
\text { Act. }\end{array}$ & $\begin{array}{l}\text { Year } \\
\text { Act. }\end{array}$ & $\begin{array}{c}\text { IMF Country } \\
\text { Report } 07 / 177\end{array}$ & Prel Act & $\begin{array}{l}\text { IMF Country } \\
\text { Report } 07 / 177\end{array}$ & Proj. & $\begin{array}{l}\text { Year } \\
\text { Proj. }\end{array}$ \\
\hline Primary balance & 975 & 1,129 & 680 & 578 & -575 & -98 & -1 & 27 & 979 \\
\hline Revenue and grants & 6,597 & 7,485 & 7,405 & 8,486 & 1,763 & 2,155 & 9,534 & 9,591 & 9,895 \\
\hline Revenue & 6,597 & 7,485 & 7,405 & 7,490 & 1,763 & 2,153 & 8,218 & 8,273 & 8,931 \\
\hline Tax revenue & 4,527 & 5,169 & 4,867 & 4,922 & 1,175 & 1,353 & 5,394 & 5,374 & 6,414 \\
\hline Taxes on income and profits & 783 & 908 & 1,047 & 1,166 & 281 & 273 & 1,236 & 1,233 & 1,408 \\
\hline Taxes on property & 321 & 405 & 414 & 579 & 106 & 125 & 441 & 441 & 522 \\
\hline Taxes on domestic goods and services & 1,560 & 1,971 & 1,896 & 1,844 & 430 & 547 & 1,996 & 2,023 & 2,618 \\
\hline Of which: VAT revenues & 1,386 & 1,763 & 1,693 & 1,659 & 389 & 499 & 1,802 & 1,830 & 2,385 \\
\hline Taxes on international trade $1 /$ & 1,645 & 1,617 & 1,268 & 1,074 & 300 & 344 & 1,450 & 1,406 & 1,580 \\
\hline Tariffs & 475 & 530 & 481 & 461 & 109 & 131 & 493 & 493 & 520 \\
\hline Excises & 1,170 & 1,087 & 787 & 613 & 191 & 213 & 957 & 913 & 1,060 \\
\hline Other taxes & 217 & 268 & 241 & 259 & 59 & 64 & 271 & 271 & 286 \\
\hline Nontax revenue & 2,070 & 2,316 & 2,538 & 2,568 & 588 & 800 & 2,824 & 2,899 & 2,517 \\
\hline Entrepreneurial and property income & 1,252 & 1,420 & 1,663 & 1,702 & 393 & 559 & 1,914 & 1,984 & 1,417 \\
\hline Profit transfer from BdL & 0 & 0 & 0 & 0 & 0 & 113 & 113 & 113 & 0 \\
\hline Other & 1,252 & 1,420 & 1,662 & 1,702 & 393 & 446 & 1,801 & 1,872 & 1,417 \\
\hline Administrative fees and charges & 383 & 365 & 365 & 426 & 90 & 97 & 393 & 393 & 415 \\
\hline Other nontax revenue & 81 & 93 & 89 & 91 & 23 & 20 & 92 & 92 & 231 \\
\hline Fines and forfeits & 6 & 5 & 4 & 4 & 1 & 1 & 4 & 4 & 4 \\
\hline Other & 75 & 88 & 85 & 87 & 22 & 19 & 88 & 88 & 227 \\
\hline Other treasury revenue & 354 & 439 & 421 & 349 & 82 & 124 & 425 & 429 & 454 \\
\hline Grants & 0 & 0 & 0 & 996 & 0 & 2 & 1,316 & 1,318 & 964 \\
\hline Primary expenditure $2 /$ & 5,622 & 6,356 & 6,725 & 7,908 & 2,338 & 2,253 & 9,535 & 9,564 & 8,916 \\
\hline Current primary expenditure & 4,708 & 5,304 & 6,025 & 7,051 & 2,008 & 1,943 & 7,770 & 7,799 & 7,754 \\
\hline Wages, salaries and pensions & 3,078 & 3,094 & 3,193 & 3,307 & 856 & 914 & 3,529 & 3,529 & 3,677 \\
\hline Wages and salaries & 2,234 & 2,284 & 2,329 & 2,386 & 643 & 682 & 2,568 & 2,568 & 2,632 \\
\hline Pensions & 844 & 810 & 864 & 927 & 213 & 232 & 961 & 961 & 1,044 \\
\hline Transfers to EDL $3 /$ & 174 & 184 & 637 & 1,137 & 315 & 310 & 1,450 & 1,430 & 1,206 \\
\hline Other current & 1,456 & 2,026 & 2,195 & 2,607 & 837 & 719 & 2,790 & 2,840 & 2,871 \\
\hline Materials and supplies & 120 & 116 & 213 & 140 & 68 & 47 & 195 & 182 & 187 \\
\hline External services & 81 & 113 & 82 & 87 & 21 & 24 & 90 & 90 & 92 \\
\hline Transfers 4/ 5/ & 271 & 360 & 655 & 878 & 419 & 334 & 819 & 887 & 853 \\
\hline Of which: NSSF & $\ldots$ & 89 & 290 & 200 & 230 & 230 & 230 & 230 & 230 \\
\hline Other & 440 & 452 & 377 & 507 & 176 & 154 & 814 & 808 & 829 \\
\hline Of which: "Housing compensations" 6/ & $\ldots$ & $\ldots$ & $\ldots$ & 136 & 60 & 80 & 452 & 452 & 465 \\
\hline Other treasury outflows $7 /$ & 544 & 985 & 868 & 995 & 153 & 160 & 872 & 872 & 909 \\
\hline Capital expenditure & 914 & 1,052 & 700 & 857 & 331 & 310 & 1,765 & 1,765 & 1,162 \\
\hline Domestically financed & 713 & 817 & 534 & 446 & 116 & 131 & 490 & 490 & 586 \\
\hline Foreign financed & 201 & 235 & 166 & 411 & 215 & 179 & 1,275 & 1,275 & 576 \\
\hline Of which: conflict reconstruction $6 /$ & $\ldots$ & $\ldots$ & $\ldots$ & 111 & 120 & 99 & 895 & 895 & 95 \\
\hline Memorandum items: & & & & & & & & & \\
\hline Underlying primary balance (excl. conflict impact) & 975 & 1,129 & 680 & -73 & -395 & 116 & 30 & 56 & 575 \\
\hline Total conflict-related budgetary spending & $\ldots$ & $\ldots$ & $\ldots$ & 345 & 180 & 216 & 1,347 & 1,347 & 560 \\
\hline Primary balance excluding grants & 975 & 1,129 & 680 & -418 & -575 & -100 & $-1,317$ & $-1,291$ & 15 \\
\hline
\end{tabular}

Sources: Ministry of Finance; and Fund staff estimates and projections.

$1 /$ Domestic excises, which are collected at customs, are classified as taxes on international trade.

$2 /$ On checks issued basis.

3/ Excludes principal and interest payments paid on behalf of EdL.

4/ From 2005 onward includes additional transfers to the social security funds (NSSF) to clear the stock of arrears.

5/ Includes (i) \$275 million for telecom settlements (2006 and 2007); and (ii) \$500 million to the Council of the South and the Displaced Fund (2007 to 2009).

$6 /$ The budgetary cost of the 2006 conflict is estimated to at $\$ 1.48$ billion.

7/ Includes transfers to municipalities. 
Table 3. Lebanon: Central Government Primary Balance, 2003-08 (In percent of GDP)

\begin{tabular}{|c|c|c|c|c|c|c|c|c|c|}
\hline & \multirow{3}{*}{$\begin{array}{c}2003 \\
\text { Year } \\
\text { Act. }\end{array}$} & \multirow{3}{*}{$\begin{array}{l}2004 \\
\text { Year } \\
\text { Act. }\end{array}$} & \multirow{3}{*}{$\begin{array}{l}2005 \\
\text { Year } \\
\text { Act. }\end{array}$} & \multirow{3}{*}{$\begin{array}{l}2006 \\
\text { Year } \\
\text { Act. }\end{array}$} & \multicolumn{4}{|c|}{2007} & \multirow{3}{*}{$\begin{array}{l}2008 \\
\text { Year } \\
\text { Proj. }\end{array}$} \\
\hline & & & & & Q1 & & Year & & \\
\hline & & & & & $\begin{array}{l}\text { IMF Country } \\
\text { Report } 07 / 177\end{array}$ & Prel Act. & $\begin{array}{l}\text { IMF Country } \\
\text { Report } 07 / 177\end{array}$ & Proj. & \\
\hline Primary balance & 3.3 & 3.5 & 2.1 & 1.7 & -1.6 & -0.3 & 0.0 & 0.1 & 2.6 \\
\hline Revenue and grants & 22.1 & 23.1 & 22.8 & 24.8 & 4.9 & 6.0 & 26.7 & 26.5 & 25.9 \\
\hline Revenue & 22.1 & 23.1 & 22.8 & 21.9 & 4.9 & 6.0 & 23.1 & 22.9 & 23.4 \\
\hline Tax revenue & 15.2 & 16.0 & 15.0 & 14.4 & 3.3 & 3.7 & 15.1 & 14.9 & 16.8 \\
\hline Taxes on income and profits & 2.6 & 2.8 & 3.2 & 3.4 & 0.8 & 0.8 & 3.5 & 3.4 & 3.7 \\
\hline Taxes on property & 1.1 & 1.3 & 1.3 & 1.7 & 0.3 & 0.3 & 1.2 & 1.2 & 1.4 \\
\hline Taxes on domestic goods and services & 5.2 & 6.1 & 5.8 & 5.4 & 1.2 & 1.5 & 5.6 & 5.6 & 6.9 \\
\hline Of which: VAT revenues & 4.6 & 5.4 & 5.2 & 4.8 & 1.1 & 1.4 & 5.1 & 5.1 & 6.2 \\
\hline Taxes on international trade $1 /$ & 5.5 & 5.0 & 3.9 & 3.1 & 0.8 & 1.0 & 4.1 & 3.9 & 4.1 \\
\hline Tariffs & 1.6 & 1.6 & 1.5 & 1.3 & 0.3 & 0.4 & 1.4 & 1.4 & 1.4 \\
\hline Excises & 3.9 & 3.4 & 2.4 & 1.8 & 0.5 & 0.6 & 2.7 & 2.5 & 2.8 \\
\hline Other taxes & 0.7 & 0.8 & 0.7 & 0.8 & 0.2 & 0.2 & 0.8 & 0.7 & 0.7 \\
\hline Nontax revenue & 6.9 & 7.2 & 7.8 & 7.5 & 1.6 & 2.2 & 7.9 & 8.0 & 6.6 \\
\hline Entrepreneurial and property income & 4.2 & 4.4 & 5.1 & 5.0 & 1.1 & 1.5 & 5.4 & 5.5 & 3.7 \\
\hline Administrative fees and charges & 1.3 & 1.1 & 1.1 & 1.2 & 0.3 & 0.3 & 1.1 & 1.1 & 1.1 \\
\hline Other nontax revenue & 0.3 & 0.3 & 0.3 & 0.3 & 0.1 & 0.1 & 0.3 & 0.3 & 0.6 \\
\hline Other treasury revenue & 1.2 & 1.4 & 1.3 & 1.0 & 0.2 & 0.3 & 1.2 & 1.2 & 1.2 \\
\hline Grants & 0.0 & 0.0 & 0.0 & 2.9 & 0.0 & 0.0 & 3.7 & 3.6 & 2.5 \\
\hline Primary expenditure $2 /$ & 18.8 & 19.6 & 20.7 & 23.1 & 6.6 & 6.2 & 26.7 & 26.4 & 23.3 \\
\hline Current primary expenditure & 15.8 & 16.4 & 18.6 & 20.6 & 5.6 & 5.4 & 21.8 & 21.6 & 20.3 \\
\hline Wages, salaries and pensions & 10.3 & 9.6 & 9.8 & 9.7 & 2.4 & 2.5 & 9.9 & 9.8 & 9.6 \\
\hline Wages and salaries & 7.5 & 7.1 & 7.2 & 7.0 & 1.8 & 1.9 & 7.2 & 7.1 & 6.9 \\
\hline Pensions & 2.8 & 2.5 & 2.7 & 2.7 & 0.6 & 0.6 & 2.7 & 2.7 & 2.7 \\
\hline Transfers to EDL $3 /$ & 0.6 & 0.6 & 2.0 & 3.3 & 0.9 & 0.9 & 4.1 & 4.0 & 3.2 \\
\hline Other current & 4.9 & 6.3 & 6.8 & 7.6 & 2.3 & 2.0 & 7.8 & 7.9 & 7.5 \\
\hline Materials and supplies & 0.4 & 0.4 & 0.7 & 0.4 & 0.2 & 0.1 & 0.5 & 0.5 & 0.5 \\
\hline External services & 0.3 & 0.3 & 0.3 & 0.3 & 0.1 & 0.1 & 0.3 & 0.2 & 0.2 \\
\hline Transfers 4/ 5/ & 0.9 & 1.1 & 2.0 & 2.6 & 1.2 & 0.9 & 2.3 & 2.5 & 2.2 \\
\hline Of which: NSSF & $\ldots$ & 0.3 & 0.9 & 0.6 & 0.6 & 0.6 & 0.6 & 0.6 & 0.6 \\
\hline Other & 1.5 & 1.4 & 1.2 & 1.5 & 0.5 & 0.4 & 2.3 & 2.2 & 2.2 \\
\hline Of which: "Housing compensations" 6/ & $\ldots$ & $\ldots$ & $\ldots$ & 0.4 & 0.2 & 0.2 & 1.3 & 1.3 & 1.2 \\
\hline Other treasury outflows $7 /$ & 1.8 & 3.0 & 2.7 & 2.9 & 0.4 & 0.4 & 2.4 & 2.4 & 2.4 \\
\hline Capital expenditure & 3.1 & 3.3 & 2.2 & 2.5 & 0.9 & 0.9 & 5.0 & 4.9 & 3.0 \\
\hline Domestically financed & 2.4 & 2.5 & 1.6 & 1.3 & 0.3 & 0.4 & 1.4 & 1.4 & 1.5 \\
\hline Foreign financed & 0.7 & 0.7 & 0.5 & 1.2 & 0.6 & 0.5 & 3.6 & 3.5 & 1.5 \\
\hline Of which: conflict reconstruction 6/ & $\ldots$ & $\ldots$ & $\ldots$ & 0.3 & 0.3 & 0.3 & 2.5 & 2.5 & 0.2 \\
\hline \multicolumn{10}{|l|}{ Memorandum items: } \\
\hline Underlying primary balance (excl. conflict impact) & 3.3 & 3.5 & 2.1 & -0.2 & -1.1 & 0.3 & 0.1 & 0.2 & 1.5 \\
\hline Total conflict-related budgetary spending & $\ldots$ & $\ldots$ & $\ldots$ & 1.0 & 0.5 & 0.6 & 3.8 & 3.7 & 1.5 \\
\hline Primary balance excluding grants & 3.3 & 3.5 & 2.1 & -1.2 & -1.6 & -0.3 & -3.7 & -3.6 & 0.0 \\
\hline
\end{tabular}

Sources: Ministry of Finance; and Fund staff estimates and projections.

$1 /$ Domestic excises, which are collected at customs, are classified as taxes on international trade.

2/ On checks issued basis.

3/ Excludes principal and interest payments paid on behalf of EdL.

4/ From 2005 onward includes additional transfers to the social security funds (NSSF) to clear the stock of arrears.

5/ Includes (i) \$275 million for telecom settlements (2006 and 2007); and (ii) \$500 million to the Council of the South and the Displaced Fund (2007 to 2009).

$6 /$ The budgetary cost of the 2006 conflict is estimated to at $\$ 1.48$ billion.

$7 /$ Includes transfers to municipalities. 
Table 4. Lebanon: Government Expenditure by Function, 2002-06 1/

\begin{tabular}{|c|c|c|c|c|c|}
\hline & 2002 & 2003 & 2004 & 2005 & 2006 \\
\hline & \multicolumn{5}{|c|}{ (In billions of Lebanese pounds) } \\
\hline Total expenditure & 9,778 & 10,564 & 10,278 & 10,135 & 12,289 \\
\hline General public services & 1,190 & 1,229 & 1,313 & 1,407 & 1,335 \\
\hline Defense & 879 & 877 & 866 & 888 & 1,005 \\
\hline Public order and safety & 352 & 368 & 354 & 381 & 427 \\
\hline Education & 721 & 785 & 795 & 902 & 835 \\
\hline Health & 240 & 346 & 315 & 287 & 321 \\
\hline Social security and welfare & 169 & 201 & 165 & 156 & 194 \\
\hline Housing & 54 & 79 & 62 & 50 & 47 \\
\hline Recreation, culture, and religious affairs & 55 & 52 & 85 & 72 & 52 \\
\hline Economic affairs and services & 1,095 & 1,275 & 1,596 & 1,742 & 2,590 \\
\hline Fuel and energy & 306 & 413 & 494 & 839 & 1,371 \\
\hline Agriculture, forestry, and fishing & 29 & 28 & 36 & 28 & 23 \\
\hline Mining, manufacturing, and construction & 4 & 11 & 10 & 5 & 3 \\
\hline Transportation and communication & 210 & 217 & 178 & 123 & 395 \\
\hline Other economic affairs and services & 546 & 606 & 879 & 747 & 798 \\
\hline Interest payments & 4,712 & 4,942 & 3,921 & 3,410 & 4,381 \\
\hline \multirow[t]{2}{*}{ Unclassified treasury expenditure 2/ } & 310 & 412 & 806 & 840 & 1,103 \\
\hline & \multicolumn{5}{|c|}{ (In percent of GDP) } \\
\hline Total expenditure & 34.7 & 35.4 & 31.8 & 31.2 & 35.9 \\
\hline General public services & 4.2 & 4.1 & 4.4 & 4.3 & 3.9 \\
\hline Defense & 3.1 & 2.9 & 2.9 & 2.7 & 2.9 \\
\hline Public order and safety & 1.2 & 1.2 & 1.2 & 1.2 & 1.2 \\
\hline Education & 2.6 & 2.6 & 2.7 & 2.8 & 2.4 \\
\hline Health & 0.9 & 1.2 & 1.1 & 0.9 & 0.9 \\
\hline Social security and welfare & 0.6 & 0.7 & 0.6 & 0.5 & 0.6 \\
\hline Housing & 0.2 & 0.3 & 0.2 & 0.2 & 0.1 \\
\hline Recreation, culture, and religious affairs & 0.2 & 0.2 & 0.3 & 0.2 & 0.2 \\
\hline Economic affairs and services & 3.9 & 4.3 & 5.3 & 5.4 & 7.6 \\
\hline Fuel and energy & 1.1 & 1.4 & 1.7 & 2.6 & 4.0 \\
\hline Agriculture, forestry, and fishing & 0.1 & 0.1 & 0.1 & 0.1 & 0.1 \\
\hline Mining, manufacturing, and construction & 0.0 & 0.0 & 0.0 & 0.0 & 0.0 \\
\hline Transportation and communication & 0.7 & 0.7 & 0.6 & 0.4 & 1.2 \\
\hline Other economic affairs and services & 1.9 & 2.0 & 2.9 & 2.3 & 2.3 \\
\hline Interest payments & 16.7 & 16.6 & 13.1 & 10.5 & 12.8 \\
\hline Unclassified treasury expenditure $2 /$ & 1.1 & 1.4 & 2.7 & 2.6 & 3.2 \\
\hline \multicolumn{6}{|l|}{ Memorandum item: } \\
\hline GDP (in billions of Lebanese pounds) & 28,216 & 29,851 & 32,357 & 32,446 & 34,253 \\
\hline
\end{tabular}

Sources: Ministry of Finance; IMF Government Finance Statistics; and Fund staff estimates.

$1 /$ Includes treasury and foreign-financed capital expenditure by the Council for Reconstruction and Development. 2/ Includes subsidies on diesel oil and interest, and transfers to municipalities. 


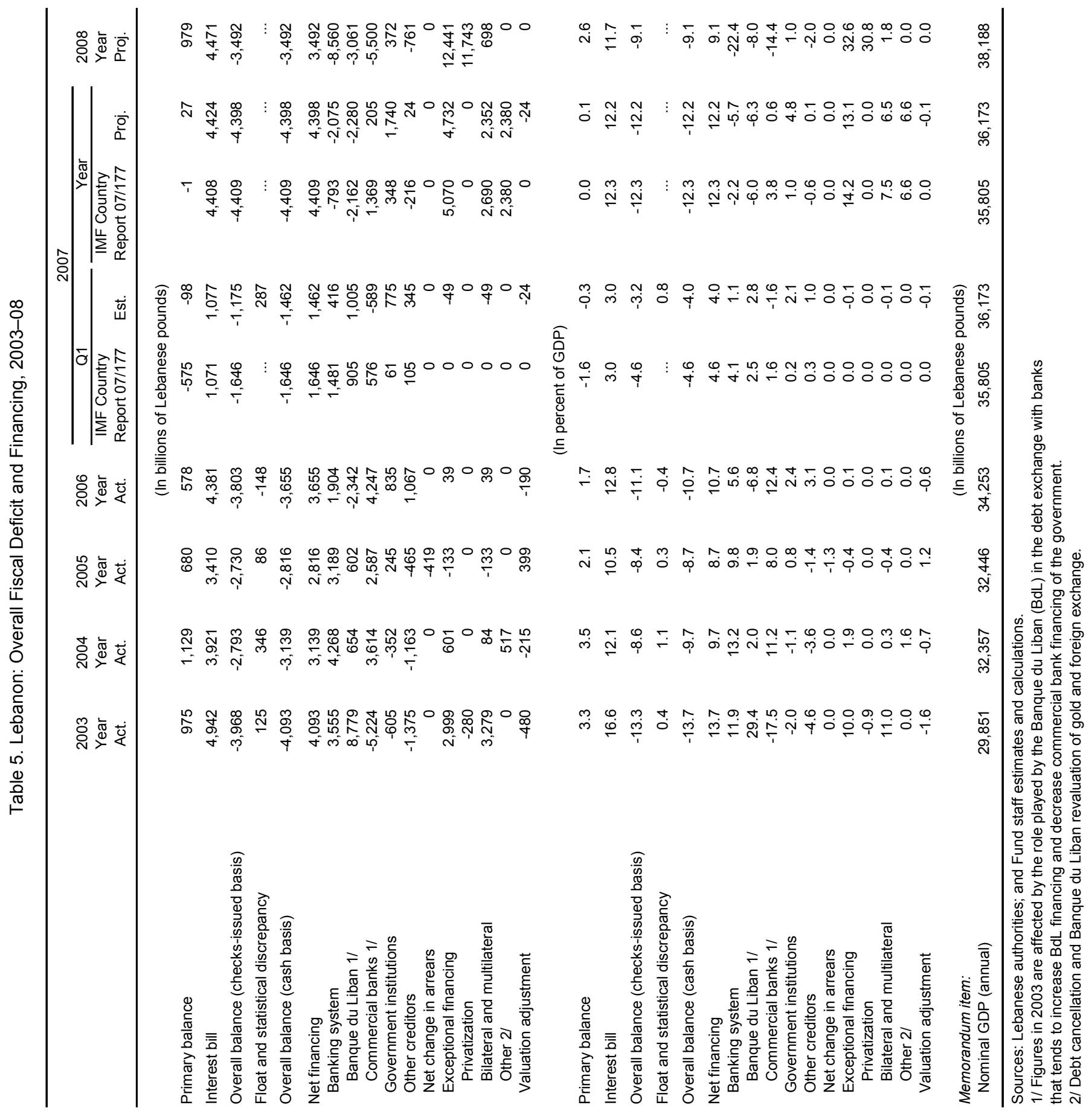




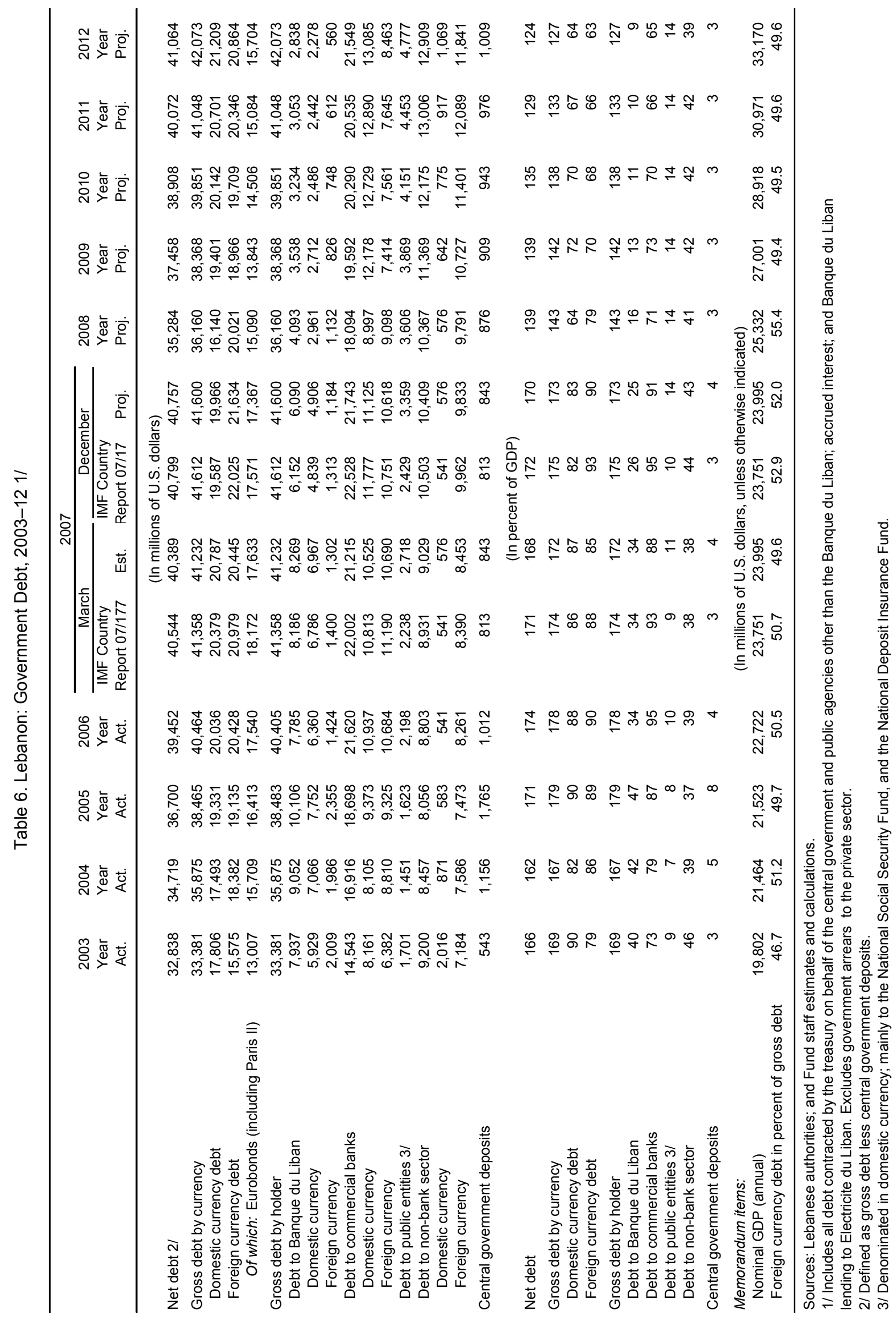


Table 7. Lebanon: Monetary Survey, 2003-08

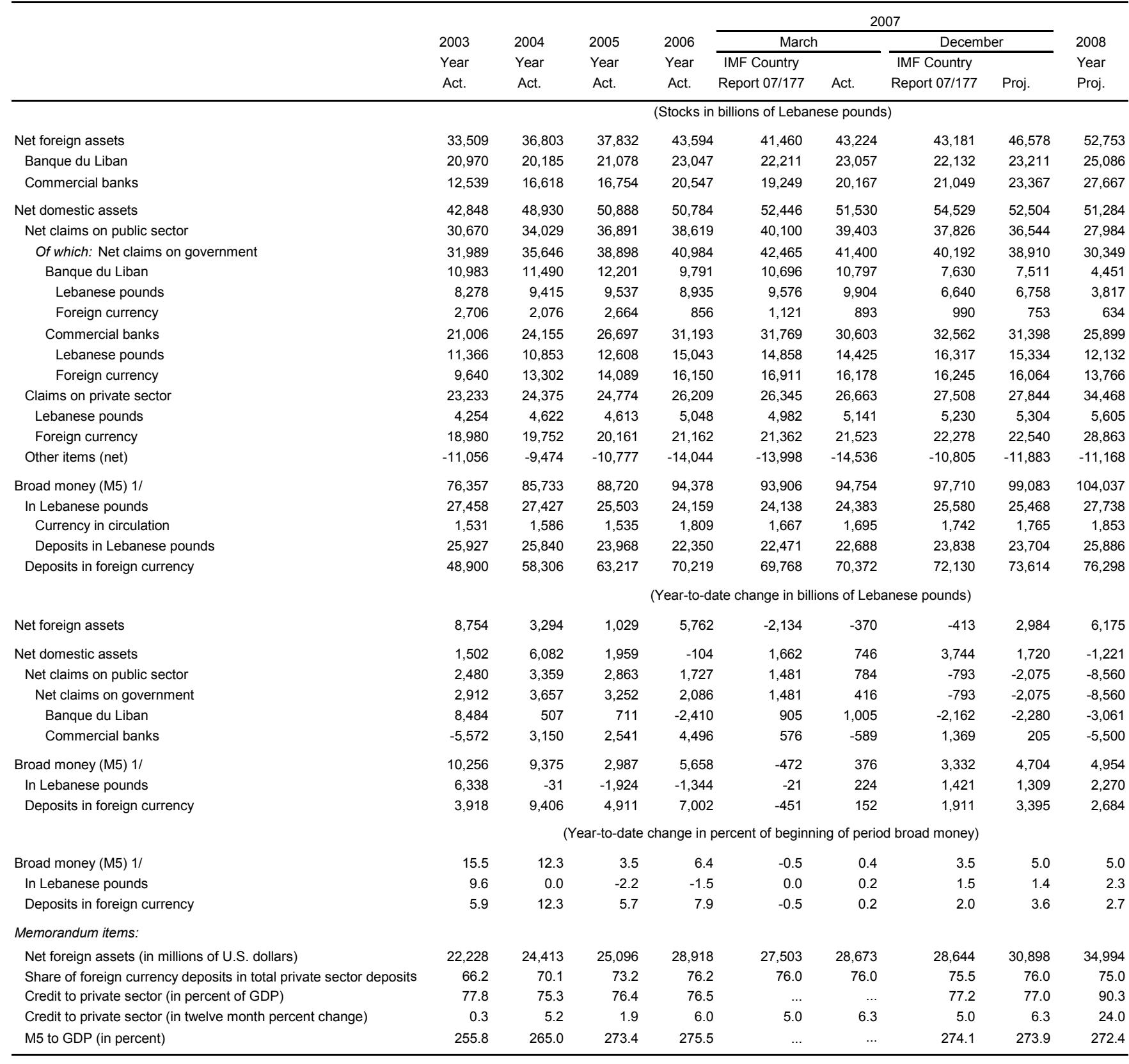

Sources: Banque du Liban; and Fund staff estimates and projections.

1/ Broad money is taken to be M5 which is defined as M3 (currency + resident deposits) + non-resident deposits. 
Table 8. Lebanon: Balance Sheet of the Banque du Liban, 2003-08

\begin{tabular}{|c|c|c|c|c|c|c|c|c|c|}
\hline & \multirow{3}{*}{$\begin{array}{c}2003 \\
\text { Year } \\
\text { Act. }\end{array}$} & \multirow{3}{*}{$\begin{array}{c}2004 \\
\text { Year } \\
\text { Act. }\end{array}$} & \multirow{3}{*}{$\begin{array}{c}2005 \\
\text { Year } \\
\text { Act. }\end{array}$} & \multicolumn{5}{|c|}{2007} & \multirow{3}{*}{$\begin{array}{l}2008 \\
\text { Year } \\
\text { Proj. }\end{array}$} \\
\hline & & & & \multirow{2}{*}{$\begin{array}{c}2006 \\
\text { Year } \\
\text { Act. }\end{array}$} & \multicolumn{2}{|c|}{ March } & \multicolumn{2}{|c|}{ December } & \\
\hline & & & & & $\begin{array}{l}\text { Country } \\
\text { rt } 07 / 177\end{array}$ & Act. & $\begin{array}{l}\text { IMF Country } \\
\text { Report } 07 / 177\end{array}$ & Proj. & \\
\hline & \multicolumn{9}{|c|}{ (Stocks in billions of Lebanese pounds) } \\
\hline Net foreign exchange position $1 /$ & 8,935 & 6,712 & 2,873 & 3,465 & 2,449 & 3,080 & 2,684 & 3,541 & 6,442 \\
\hline Foreign assets & 21,263 & 20,473 & 22,081 & 26,321 & 25,485 & 26,330 & 25,570 & 26,648 & 28,497 \\
\hline Of which: gold & 5,779 & 6,039 & 7,140 & 8,755 & 9,379 & 9,215 & 9,379 & 9,432 & 9,432 \\
\hline Foreign currency liabilities & 12,328 & 13,762 & 19,208 & 22,856 & 23,036 & 23,250 & 22,886 & 23,107 & 22,055 \\
\hline Of which: commercial bank deposits $2 /$ & 11,776 & 13,213 & 17,901 & 19,189 & 19,382 & 19,660 & 19,067 & 19,328 & 18,303 \\
\hline Of which: other foreign liabilities $3 /$ & 293 & 288 & 1,003 & 3,274 & 3,274 & 3,273 & 3,439 & 3,438 & 3,411 \\
\hline Net domestic assets & $-2,528$ & 1,411 & 4,491 & 3,762 & 4,893 & 4,401 & 5,052 & 4,657 & 2,403 \\
\hline Claims on public sector (net) & 10,990 & 11,354 & 11,900 & 9,005 & 9,910 & 10,010 & 6,843 & 6,725 & 3,664 \\
\hline Net claims on government & 10,983 & 11,490 & 12,201 & 9,791 & 10,696 & 10,797 & 7,630 & 7,511 & 4,451 \\
\hline Credit & 11,800 & 13,232 & 14,860 & 11,318 & 11,922 & 12,069 & 8,856 & 8,783 & 5,772 \\
\hline Treasury bills & 8,772 & 10,238 & 11,310 & 9,170 & 9,813 & 10,106 & 6,877 & 6,998 & 4,067 \\
\hline Eurobonds & 3,028 & 2,994 & 3,550 & 2,147 & 2,110 & 1,963 & 1,979 & 1,785 & 1,706 \\
\hline Deposits & 817 & 1,741 & 2,659 & 1,526 & 1,226 & 1,272 & 1,226 & 1,272 & 1,322 \\
\hline Net claims on non financial public institutions & 7 & -137 & -302 & -787 & -787 & -787 & -787 & -787 & -787 \\
\hline Claims on private sector in Lebanese pounds (net) & 375 & 313 & 257 & 232 & 240 & 238 & 240 & 242 & 242 \\
\hline Claims on commercial banks & $-9,859$ & $-7,657$ & $-6,163$ & $-3,796$ & $-3,879$ & $-3,814$ & $-3,847$ & $-2,923$ & $-2,837$ \\
\hline Of which: Certificates of deposit in Lebanese pounds & $-11,686$ & $-9,516$ & $-7,959$ & $-5,639$ & $-5,639$ & $-5,579$ & $-5,608$ & $-4,679$ & $-4,593$ \\
\hline Claims on specialized banks in Lebanese pounds (net) & $-1,032$ & $-1,004$ & -837 & -539 & -509 & -513 & -509 & -524 & -524 \\
\hline Other items (net) & $-3,002$ & $-1,595$ & -665 & $-1,140$ & -869 & $-1,520$ & 2,324 & 1,137 & 1,857 \\
\hline Reserve money & 6,407 & 8,123 & 7,364 & 7,227 & 7,342 & 7,481 & 7,736 & 8,198 & 8,845 \\
\hline Currency issued & 1,717 & 1,783 & 1,736 & 2,010 & 1,916 & 1,931 & 1,993 & 2,019 & 2,120 \\
\hline \multirow[t]{2}{*}{ Commercial bank deposits in Lebanese pounds } & 4,690 & 6,340 & 5,628 & 5,217 & 5,426 & 5,550 & 5,743 & 6,179 & 6,725 \\
\hline & \multicolumn{9}{|c|}{ (Year-to-date flows in billions of Lebanese pounds) } \\
\hline Reserve money & 1,753 & 1,715 & -759 & -137 & 115 & 254 & 509 & 971 & 646 \\
\hline Currency issued & 176 & 66 & -47 & 274 & -95 & -79 & -17 & 9 & 101 \\
\hline \multirow[t]{2}{*}{ Commercial bank deposits in Lebanese pounds } & 1,577 & 1,649 & -711 & -412 & 210 & 333 & 526 & 963 & 545 \\
\hline & \multicolumn{9}{|c|}{ (Year-to-date changes in percent of beginning-of-period reserve money) } \\
\hline \multirow[t]{2}{*}{ Reserve money } & 38 & 27 & -9 & -2 & 2 & 4 & 7 & 13 & 8 \\
\hline & \multicolumn{9}{|c|}{ (In millions of U.S. dollars) } \\
\hline \multicolumn{10}{|l|}{ Memorandum items: } \\
\hline Gross international reserves (including gold) 4/ & 14,105 & 13,581 & 14,347 & 17,160 & 16,605 & 17,166 & 16,662 & 17,377 & 18,603 \\
\hline Gross international reserves (excluding gold) 4/ & 10,271 & 9,575 & 9,611 & 11,353 & 10,383 & 11,053 & 10,440 & 11,121 & 12,347 \\
\hline In percent of banking system foreign currency deposits & 40 & 32 & 29 & 30 & 27 & 29 & 27 & 28 & 30 \\
\hline In percent of total banking system deposits & 25 & 21 & 20 & 22 & 20 & 21 & 19 & 20 & 21 \\
\hline Program gross reserves $5 /$ & 16,113 & 15,567 & 16,202 & 18,084 & 17,505 & 17,647 & 17,475 & 17,613 & 18,837 \\
\hline Lebanese pound money multiplier & 4.3 & 3.4 & 3.5 & 3.4 & 3.3 & 3.3 & 3.3 & 3.2 & 3.2 \\
\hline
\end{tabular}

Sources: Banque du Liban; and Fund staff estimates and projections.

$1 /$ Defined by currency (not by residency), as official foreign currency assets, including gold and SDR, less foreign currency liabilities.

These include the $\$ 1.5$ billion deposits by the Saudi and Kuwaiti governments in August 2006, but exclude liabilities to the government of Lebanon and other official creditors. $2 /$ Includes certificates of deposits in foreign currency held by commercial banks.

3/ Includes the deposits by the Saudi and Kuwaiti governments. Excludes all other special bilateral long-term deposits.

4/ Defined as all official foreign currency assets, less encumbered foreign assets.

5/ Defined as gross international reserves including gold and Eurobonds issued by the Republic of Lebanon. 


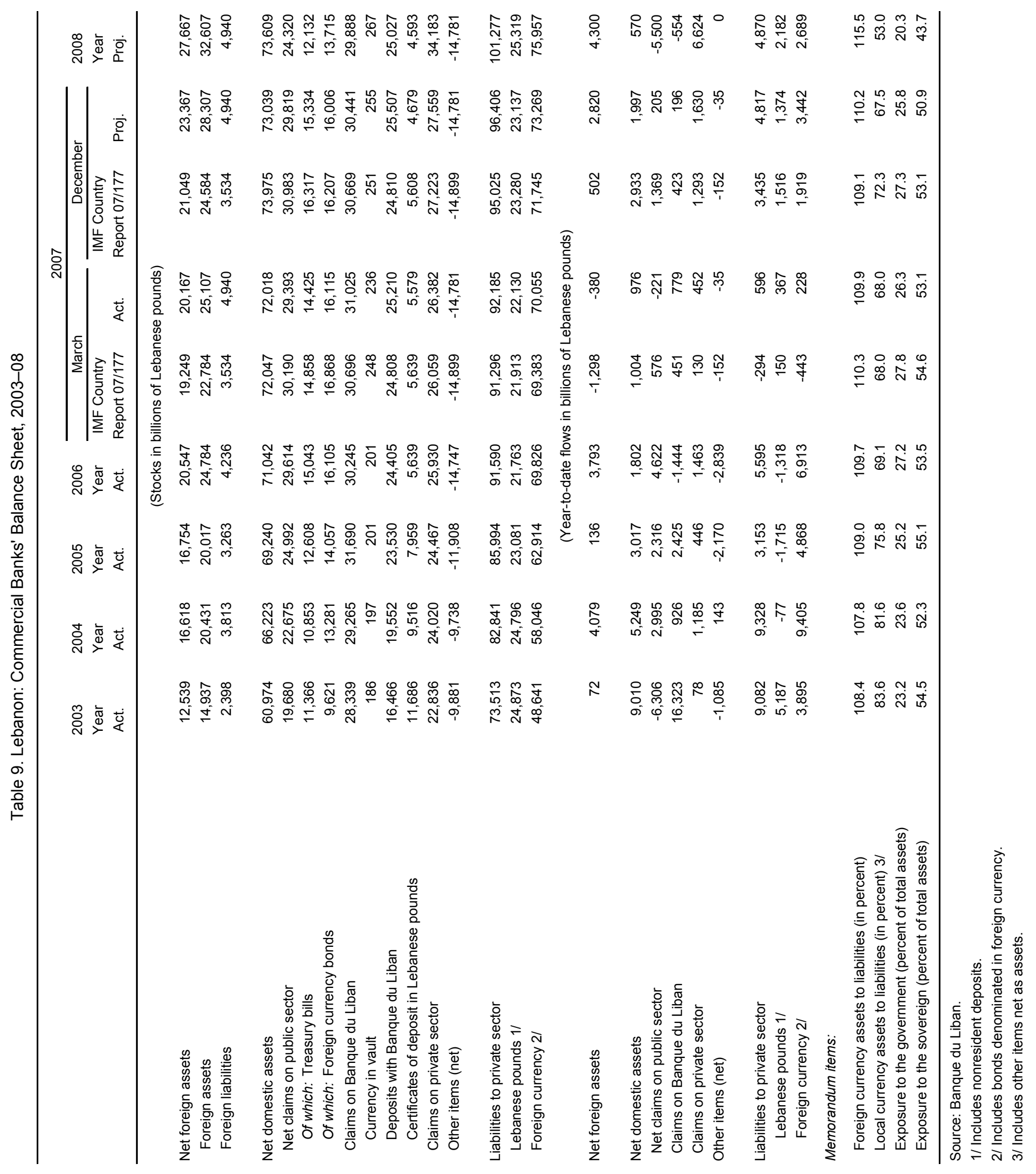


Table 10. Lebanon: Balance of Payments, 2003-12

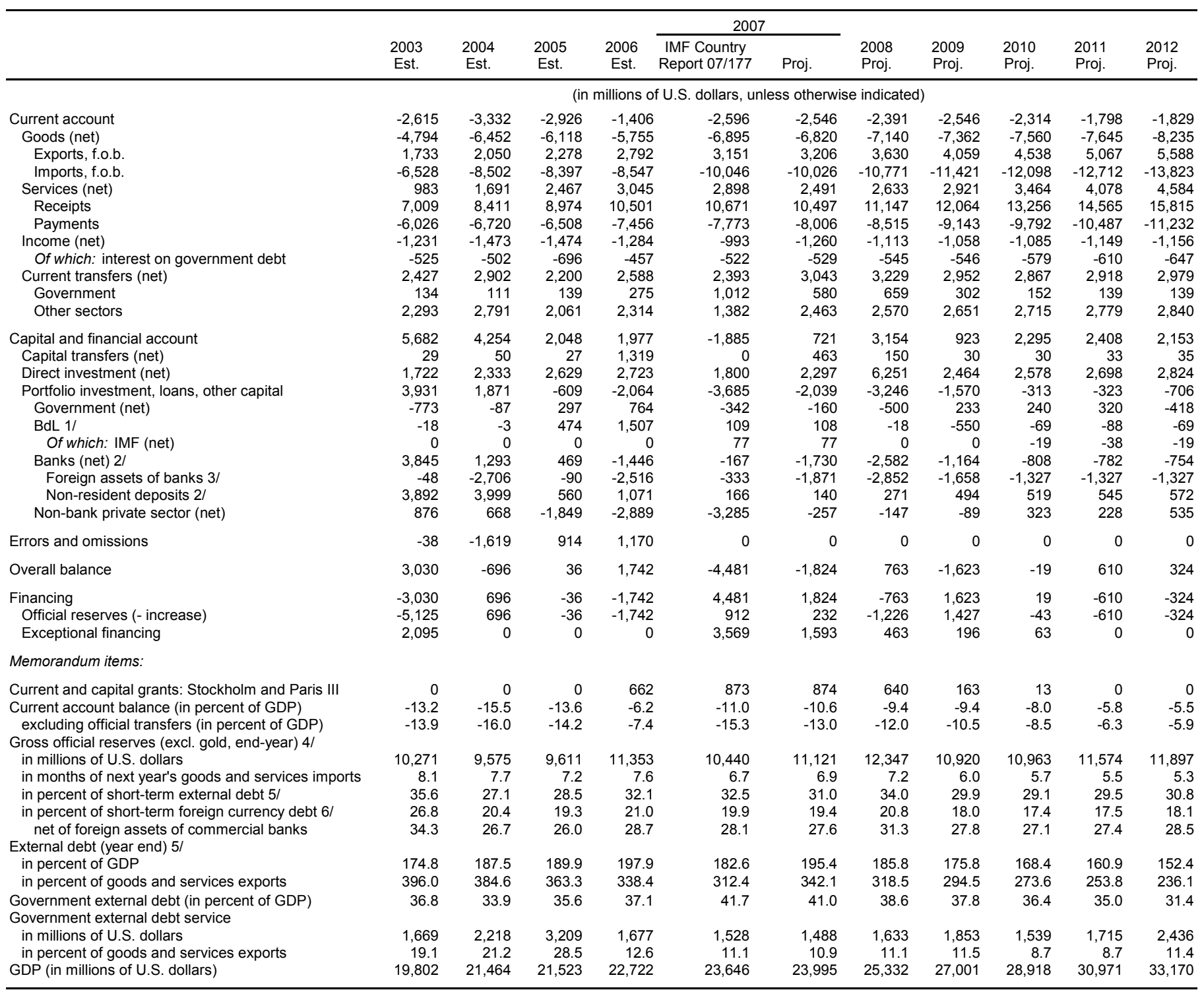

Sources: Lebanese authorities; BIS; and IMF staff estimates and projections.

$1 /$ Change in the foreign liabilities of the BdL.

2/ Differs from banks' reported data, to include estimated deposit flows by Lebanese nationals living abroad but classified as residents.

3/ Net of non-deposit foreign liabilities.

4/ Excludes Eurobonds and encumbered reserves.

$5 /$ Includes all banking deposits held by non-residents, including estimated deposits of Lebanese nationals living abroad but classified as residents

$6 /$ Includes private sector foreign currency deposits in commercial banks. 


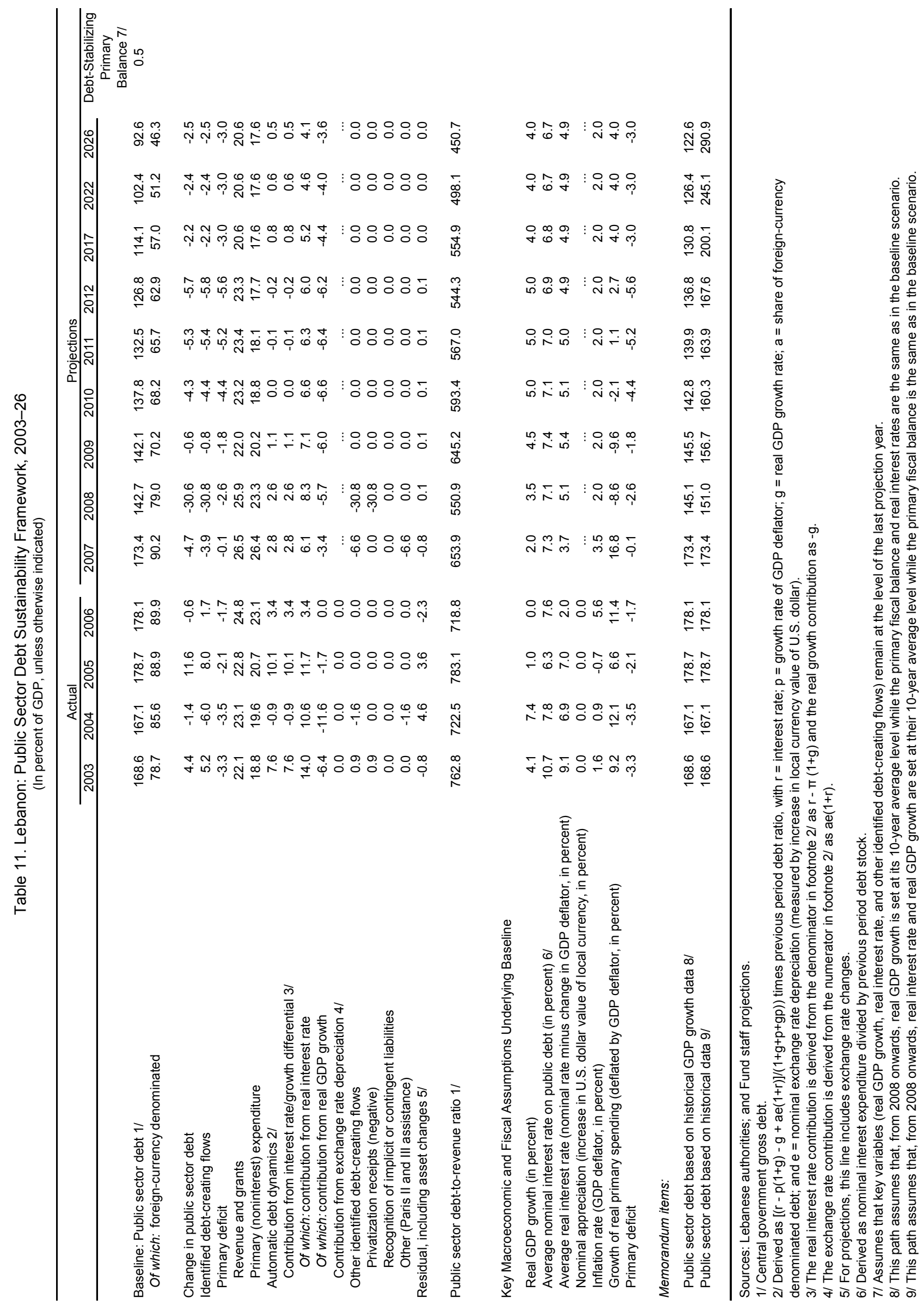


Table 12. Lebanon: National Social Security Fund Operations, 2000-06

\begin{tabular}{|c|c|c|c|c|c|c|c|}
\hline & $\begin{array}{c}2000 \\
\text { Year } \\
\text { Act. }\end{array}$ & $\begin{array}{c}2001 \\
\text { Year } \\
\text { Act. }\end{array}$ & $\begin{array}{c}2002 \\
\text { Year } \\
\text { Act. }\end{array}$ & $\begin{array}{r}2003 \\
\text { Year } \\
\text { Act. }\end{array}$ & $\begin{array}{r}2004 \\
\text { Year } \\
\text { Act. }\end{array}$ & $\begin{array}{r}2005 \\
\text { Year } \\
\text { Act. }\end{array}$ & $\begin{array}{r}2006 \\
\text { Year } \\
\text { Est. }\end{array}$ \\
\hline & \multicolumn{7}{|c|}{ (In percent of GDP) } \\
\hline \multicolumn{8}{|l|}{ Total NSSF operations } \\
\hline Revenue & 4.7 & 4.1 & 3.8 & 3.7 & 3.5 & 3.9 & 3.8 \\
\hline Expenditure & 2.6 & 3.3 & 3.5 & 3.0 & 2.7 & 2.6 & 2.7 \\
\hline Balance & 2.0 & 0.8 & 0.4 & 0.7 & 0.8 & 1.3 & 1.1 \\
\hline \multicolumn{8}{|l|}{ Healthcare } \\
\hline Revenue & 1.3 & 1.1 & 1.0 & 0.9 & 1.0 & 1.5 & 1.2 \\
\hline Expenditure & 1.0 & 1.4 & 1.5 & 1.5 & 1.4 & 1.4 & 1.5 \\
\hline Balance & 0.3 & -0.3 & -0.5 & -0.6 & -0.3 & 0.1 & -0.3 \\
\hline \multicolumn{8}{|l|}{ Family allowances } \\
\hline Revenue & 1.1 & 0.8 & 0.6 & 0.5 & 0.5 & 0.7 & 0.5 \\
\hline Expenditure & 0.8 & 0.8 & 0.8 & 0.8 & 0.8 & 0.8 & 0.7 \\
\hline Balance & 0.3 & -0.1 & -0.3 & -0.3 & -0.2 & -0.1 & -0.2 \\
\hline \multicolumn{8}{|l|}{ Retirement } \\
\hline Revenue & 2.2 & 2.3 & 2.3 & 2.3 & 1.9 & 1.8 & 2.1 \\
\hline Expenditure & 0.7 & 1.0 & 1.1 & 0.7 & 0.5 & 0.5 & 0.5 \\
\hline Balance & 1.5 & 1.2 & 1.2 & 1.6 & 1.4 & 1.3 & 1.6 \\
\hline \multicolumn{8}{|l|}{ NSSF assets (end-of-period) } \\
\hline Treasury bills & 8.6 & 9.4 & 8.9 & 5.9 & 4.2 & 4.6 & n.a. \\
\hline Bank deposits & 0.8 & 0.7 & 0.7 & 3.8 & 5.7 & 6.5 & n.a. \\
\hline Other & 0.5 & 0.7 & 0.8 & 1.1 & 1.1 & 0.1 & n.a. \\
\hline Total assets & 10.0 & 10.7 & 10.4 & 10.8 & 11.0 & 11.2 & n.a. \\
\hline GDP (in billions of Lebanese $\mathrm{k}$ & 25,359 & 25,947 & 28,216 & 29,851 & 32,357 & 32,446 & 34,253 \\
\hline
\end{tabular}

Source: National Social Security Fund (NSSF). 
Table 13. Lebanon: Interest Rates, 2003-07

(In percent, end-of-period)

\begin{tabular}{|c|c|c|c|c|c|}
\hline & $\begin{array}{l}2003 \\
\text { Year }\end{array}$ & $\begin{array}{l}2004 \\
\text { Year }\end{array}$ & $\begin{array}{l}2005 \\
\text { Year }\end{array}$ & $\begin{array}{l}2006 \\
\text { Year }\end{array}$ & $\begin{array}{l}2007 \\
\text { Apr. }\end{array}$ \\
\hline \multicolumn{6}{|l|}{ Government (yield) } \\
\hline Treasury bills, 3 months & 5.5 & 5.2 & 5.2 & 5.2 & 5.2 \\
\hline Treasury bills, 6 months & 6.5 & 6.3 & 7.2 & 7.2 & 7.2 \\
\hline Treasury bills, 1 year & 6.9 & 6.7 & 7.8 & 7.8 & 7.8 \\
\hline Treasury bills, 2 years & 8.0 & 7.9 & 8.7 & 8.7 & 8.7 \\
\hline Treasury bills, 3 years & 8.9 & 8.9 & 9.6 & 9.5 & 9.5 \\
\hline Eurobond, 5 years & 7.0 & 7.0 & 7.5 & 7.5 & 8.8 \\
\hline \multicolumn{6}{|l|}{ Banque du Liban } \\
\hline Certificates of deposit in LL, 60 days & 4.9 & 4.9 & 4.9 & 4.9 & 4.9 \\
\hline Certificates of deposit in LL, 3 years & 9.4 & 9.4 & 9.4 & 9.4 & 9.4 \\
\hline Certificates of deposit in USD, 3 years & $\ldots$ & $\ldots$ & 7.5 & 7.5 & 7.5 \\
\hline Foreign currency deposits, 2 years or more & $\ldots$ & 3.8 & 5.3 & 5.1 & 5.1 \\
\hline \multicolumn{6}{|l|}{ Commercial banks } \\
\hline Deposits in LL, 1 year or more & 8.3 & 7.6 & 8.5 & 7.6 & 7.1 \\
\hline Deposits in LL, weighted average & 7.8 & 7.0 & 7.7 & 7.5 & 7.5 \\
\hline Deposits in USD, 1 year or more & 4.7 & 4.3 & 6.0 & 6.2 & 6.2 \\
\hline Deposits in USD, weighted average & 3.4 & 3.3 & 4.1 & 4.8 & 4.8 \\
\hline Lending in LL, weighted average & 11.3 & 10.5 & 10.1 & 10.4 & 10.4 \\
\hline Lending in USD, weighted average & 8.8 & 8.0 & 8.4 & 8.6 & 8.4 \\
\hline
\end{tabular}

Source: Banque du Liban. 
Table 14. Lebanon: Banking Sector Financial Soundness Indicators, 2003-07

\begin{tabular}{|c|c|c|c|c|c|}
\hline & $\begin{array}{l}2003 \\
\text { Year }\end{array}$ & $\begin{array}{l}2004 \\
\text { Year }\end{array}$ & $\begin{array}{l}2005 \\
\text { Year }\end{array}$ & $\begin{array}{l}2006 \\
\text { Year }\end{array}$ & $\begin{array}{c}2007 \\
\text { Feb. }\end{array}$ \\
\hline & \multicolumn{5}{|c|}{ (In percent, unless otherwise specified) } \\
\hline Assets (in millions of U.S. dollars) & 61,589 & 70,595 & 73,565 & 79,948 & 79,140 \\
\hline $\begin{array}{l}\text { Capital } \\
\text { Capital adequacy ratio } 1 / \\
\text { Capital to asset ratio }\end{array}$ & $\begin{array}{r}22.3 \\
6.9\end{array}$ & $\begin{array}{r}21.2 \\
6.8\end{array}$ & $\begin{array}{r}22.9 \\
7.5\end{array}$ & $\begin{array}{r}24.7 \\
8.4\end{array}$ & $\begin{array}{l}\mathrm{n} / \mathrm{a} \\
9.4\end{array}$ \\
\hline $\begin{array}{l}\text { Asset quality } \\
\text { Net problem loans/net total loans } \\
\text { Provisions against problem loans/problem loans } \\
\text { Total provisions/problem loans }\end{array}$ & $\begin{array}{l}12.8 \\
46.3 \\
53.1\end{array}$ & $\begin{array}{l}10.6 \\
46.1 \\
57.3\end{array}$ & $\begin{array}{r}9.1 \\
49.0 \\
63.3\end{array}$ & $\begin{array}{r}6.9 \\
53.9 \\
72.0\end{array}$ & $\begin{array}{r}6.8 \\
54.2 \\
73.0\end{array}$ \\
\hline $\begin{array}{l}\text { Asset concentration } \\
\text { Share of claims on government 2/ } \\
\text { Of which: T-bills } \\
\text { Of which: Eurobonds } \\
\text { Share of claims on BdL 2/ } \\
\text { Of which: Certificates of Deposit } \\
\text { Share of claims on private sector 2/ } \\
\text { Share of claims on nonresidents 2/ } \\
\text { Of which: foreign banks } \\
\text { Net foreign currency assets as percent of capital }\end{array}$ & $\begin{array}{l}23.2 \\
12.6 \\
10.6 \\
31.3 \\
16.1 \\
25.2 \\
14.4 \\
13.4 \\
22.0\end{array}$ & $\begin{array}{l}23.6 \\
10.6 \\
13.0 \\
28.6 \\
12.0 \\
23.5 \\
17.6 \\
16.3 \\
23.3\end{array}$ & $\begin{array}{l}25.2 \\
11.9 \\
13.3 \\
29.9 \\
13.4 \\
23.1 \\
16.4 \\
14.9 \\
18.3\end{array}$ & $\begin{array}{l}27.2 \\
13.1 \\
14.0 \\
26.3 \\
11.5 \\
22.6 \\
12.3 \\
14.7 \\
17.1\end{array}$ & $\begin{array}{r}26.2 \\
12.4 \\
13.8 \\
27.0 \\
11.4 \\
23.1 \\
11.3 \\
\mathrm{n} / \mathrm{a} \\
17.0\end{array}$ \\
\hline $\begin{array}{l}\text { Earnings } \\
\text { Average return on assets (post tax) } 3 / \\
\text { Average return on equity (post tax) } 3 / \\
\text { Net interest margin }\end{array}$ & $\begin{array}{r}0.7 \\
10.9 \\
2.1\end{array}$ & $\begin{array}{l}0.7 \\
9.3 \\
1.7\end{array}$ & $\begin{array}{r}0.7 \\
11.0 \\
1.8\end{array}$ & $\begin{array}{r}0.9 \\
10.6 \\
2.0\end{array}$ & $\begin{array}{l}0.9 \\
9.8 \\
\mathrm{n} / \mathrm{a}\end{array}$ \\
\hline $\begin{array}{l}\text { Liquidity } \\
\text { Net liquid assets/total assets } \\
\text { Net liquid assets/short-term liabilities } \\
\text { Private sector deposits/assets } 2 / \\
\text { Nonresident deposits/assets }\end{array}$ & $\begin{array}{l}49.1 \\
56.6 \\
68.2 \\
12.9\end{array}$ & $\begin{array}{l}43.2 \\
57.0 \\
66.8 \\
14.1\end{array}$ & $\begin{array}{l}45.2 \\
52.8 \\
67.6 \\
13.5\end{array}$ & $\begin{array}{l}42.9 \\
51.0 \\
67.4 \\
12.3\end{array}$ & $\begin{array}{l}42.9 \\
51.3 \\
69.0 \\
11.3\end{array}$ \\
\hline $\begin{array}{l}\text { Other indicators } 4 / \\
\text { Change in assets ( } 12 \text { month, in percent) } \\
\text { Change in private sector credit (12 month, in percent) } 2 / \\
\text { Change in deposits ( } 12 \text { month, in percent) } 2 / \\
\text { FC deposits/total deposits } 5 / \\
\text { FC loans/total loans } \\
\text { FC loans/GDP } \\
\text { Exports of goods and services/GDP }\end{array}$ & $\begin{array}{r}12.8 \\
0.3 \\
15.5 \\
66.2 \\
87.0 \\
62.8 \\
42.7\end{array}$ & $\begin{array}{r}15.2 \\
5.2 \\
12.3 \\
70.1 \\
86.4 \\
61.7 \\
49.0\end{array}$ & $\begin{array}{r}4.2 \\
1.9 \\
3.5 \\
73.2 \\
86.6 \\
69.5 \\
54.1\end{array}$ & $\begin{array}{r}8.7 \\
6.0 \\
6.8 \\
75.7 \\
87.0 \\
75.7 \\
58.5\end{array}$ & $\begin{array}{r}5.8 \\
6.1 \\
3.7 \\
75.5 \\
87.0 \\
76.4 \\
\text { n/a }\end{array}$ \\
\hline $\begin{array}{l}\text { Memorandum items: 2/ } \\
\text { LL deposit rate (average) } \\
\text { LL loan rate (average) } \\
\text { FC deposit rate (average) } \\
\text { FC loan rate (average) } \\
\text { Government's 2-year T-bill rate (marginal) } \\
\text { Spread over 6-month USD Libor } \\
\text { Government's Eurobond rate (marginal) } \\
\text { Spread over 5-year U.S. note }\end{array}$ & $\begin{array}{r}7.8 \\
13.4 \\
3.6 \\
9.0 \\
8.0 \\
6.8 \\
7.0 \\
4.0\end{array}$ & $\begin{array}{r}7.1 \\
10.8 \\
3.3 \\
8.3 \\
7.9 \\
6.1 \\
7.0 \\
3.5\end{array}$ & $\begin{array}{r}7.7 \\
10.6 \\
3.7 \\
8.2 \\
8.7 \\
4.8 \\
7.5 \\
2.7\end{array}$ & $\begin{array}{r}7.5 \\
10.3 \\
4.4 \\
8.5 \\
8.7 \\
3.4 \\
7.5 \\
1.8\end{array}$ & $\begin{array}{r}7.6 \\
10.4 \\
4.3 \\
8.4 \\
8.7 \\
3.3 \\
8.8 \\
3.2\end{array}$ \\
\hline GDP (in millions of U.S. dollars) & 19,802 & 21,464 & 21,523 & 22,722 & $\mathrm{n} / \mathrm{a}$ \\
\hline
\end{tabular}

Sources: Banque du Liban, Banking Control Commission and staff estimates.

$1 /$ As of June 2006.

2/ 2007 figures are as of April.

3/ 2007 figures are the annualized February data.

4/ FC and LL stand for "foreign currency" and "Lebanese pound", respectively.

5/ FC deposits of residents and nonresidents as a share of total deposits of residents and nonresidents. 
Table 15. Lebanon: Indicators of Financial and External Vulnerability, 2003-07

\begin{tabular}{|c|c|c|c|c|c|}
\hline & $\begin{array}{l}2003 \\
\text { Year }\end{array}$ & $\begin{array}{l}2004 \\
\text { Year }\end{array}$ & $\begin{array}{l}2005 \\
\text { Year }\end{array}$ & $\begin{array}{l}2006 \\
\text { Year }\end{array}$ & $\begin{array}{r}2007 \\
\text { March }\end{array}$ \\
\hline \multicolumn{6}{|l|}{ Monetary and financial indicators } \\
\hline Broad money, M5 (annual percentage change) & 15.5 & 12.3 & 3.5 & 6.4 & 4.7 \\
\hline Private-sector credit (annual percentage change) & 0.3 & 5.2 & 1.9 & 6.0 & 6.3 \\
\hline Broad money, M5 (in millions of U.S. dollars) & 50,652 & 56,871 & 58,852 & 62,606 & 62,855 \\
\hline \multicolumn{6}{|l|}{ Public finance indicators } \\
\hline Overall fiscal balance (in millions of U.S. dollars) & $-2,632$ & $-1,852$ & $-1,811$ & $-2,523$ & -780 \\
\hline In percent of GDP 1/ & -13.3 & -8.6 & -8.4 & -11.1 & -13.4 \\
\hline In percent of government revenue & -60.1 & -37.3 & -36.9 & -44.8 & -54.5 \\
\hline Interest payments on debt (in millions of U.S. dollars) & 3,280 & 2,602 & 2,263 & 2,906 & 715 \\
\hline In percent of GDP 1/ & 16.6 & 12.1 & 10.5 & 12.8 & 12.3 \\
\hline In percent of government revenue & 74.9 & 52.4 & 46.0 & 51.6 & 50.0 \\
\hline Nominal GDP (in millions of U.S. dollars) 1/ & 19,802 & 21,464 & 21,523 & 22,722 & 23,234 \\
\hline \multirow[t]{2}{*}{ Government revenue (in millions of U.S. dollars) } & 4,377 & 4,967 & 4,914 & 5,631 & 1,430 \\
\hline & \multicolumn{5}{|c|}{ (In percent) } \\
\hline \multicolumn{6}{|l|}{ Banking-sector indicators } \\
\hline Problem loans/total loans (net of provisions and unearned interest) 2/ & 12.8 & 10.6 & 9.1 & 6.9 & 6.8 \\
\hline Provisions against problem loans/problem loans $2 /$ & 46.3 & 46.1 & 49.0 & 53.9 & 54.2 \\
\hline Capital adequacy ratio & 22.3 & 21.2 & 22.9 & 24.7 & $\mathrm{n} / \mathrm{a}$ \\
\hline \multirow[t]{2}{*}{ Credit to the private sector (in percent of GDP) } & 77.8 & 75.3 & 76.4 & 76.5 & 0.0 \\
\hline & \multicolumn{5}{|c|}{ (In millions of U.S. dollars) } \\
\hline \multicolumn{6}{|l|}{ Debt indicators } \\
\hline Gross public debt & 33,381 & 35,875 & 38,483 & 40,405 & 41,232 \\
\hline In percent of government revenue $1 /$ & 762.6 & 722.3 & 783.2 & 717.6 & 720.9 \\
\hline In percent of GDP $1 /$ & 168.6 & 167.1 & 178.8 & 177.8 & 177.5 \\
\hline Of which: foreign currency & 15,575 & 18,382 & 19,135 & 20,428 & 20,445 \\
\hline In percent of GDP 1/ & 78.7 & 85.6 & 88.9 & 89.9 & 88.0 \\
\hline Gross public debt held by the market & 23,743 & 25,372 & 26,754 & 30,423 & 30,934 \\
\hline In percent of GDP 1/ & 119.9 & 118.2 & 124.3 & 133.9 & 133.1 \\
\hline External debt $3 /$ & 34,621 & 40,236 & 40,879 & 44,977 & 45,701 \\
\hline In percent of GDP 1/ & 174.8 & 187.5 & 189.9 & 197.9 & 196.7 \\
\hline External public debt (central government and Banque du Liban) & 7,483 & 7,462 & 8,328 & 10,599 & 10,641 \\
\hline In percent of GDP $1 /$ & 37.8 & 34.8 & 38.7 & 46.6 & 45.8 \\
\hline Short-term external public debt $4 /$ & 1,716 & 2,512 & 1,220 & 960 & 947 \\
\hline Short-term foreign currency public debt 4 / & 1,770 & 2,452 & 2,838 & 1,827 & $\mathrm{n} / \mathrm{a}$ \\
\hline Short-term external debt $3 / 4 /$ & 28,855 & 35,286 & 33,770 & 35,338 & 36,007 \\
\hline Short-term foreign currency debt $4 / 5 /$ & 38,318 & 46,875 & 49,707 & 54,038 & 46,471 \\
\hline Total foreign currency deposits (resident and non-resident) $3 /$ & 32,266 & 38,505 & 41,734 & 46,319 & 46,471 \\
\hline \multicolumn{6}{|l|}{ International reserves } \\
\hline Gross official reserves 6/ & 10,271 & 9,575 & 9,611 & 11,353 & 11,053 \\
\hline In percent of short-term external debt & 35.6 & 27.1 & 28.5 & 32.1 & 30.7 \\
\hline In percent of short-term ext. debt, plus short-term domestic public debt in f.c. $7 /$ & 34.4 & 26.2 & 27.0 & 31.1 & $\ldots$ \\
\hline In percent of short-term ext. debt, plus residents' f.c. deposits minus banks' foreign assets & 34.3 & 26.7 & 26.0 & 28.7 & 27.4 \\
\hline Gross official reserves and commercial banks' foreign assets & 18,589 & 20,599 & 20,725 & 24,983 & 24,431 \\
\hline In percent of short-term external debt & 64.4 & 58.4 & 61.4 & 70.7 & 67.8 \\
\hline \multirow[t]{2}{*}{ In percent of short-term foreign currency debt $5 /$} & 48.5 & 43.9 & 41.7 & 46.2 & 52.6 \\
\hline & \multicolumn{5}{|c|}{ (In millions of U.S. dollars) } \\
\hline \multicolumn{6}{|l|}{ External current account indicators } \\
\hline Merchandise exports, f.o.b. & 1,733 & 2,050 & 2,278 & 2,792 & 769 \\
\hline Annual percentage change & 43.2 & 18.3 & 11.1 & 22.5 & $\ldots$ \\
\hline Merchandise imports, f.o.b. & 6,528 & 8,502 & 8,397 & 8,547 & 2,306 \\
\hline Annual percentage change & 10.4 & 30.3 & -1.2 & 1.8 & $\ldots$ \\
\hline External current account balance & $-2,615$ & $-3,332$ & $-2,926$ & $-1,406$ & -569 \\
\hline In percent of GDP & -13.2 & -15.5 & -13.6 & -6.2 & -9.8 \\
\hline In percent of exports of goods and services & -29.9 & -31.9 & -26.0 & -10.6 & $\ldots$ \\
\hline
\end{tabular}

Sources: Lebanese authorities; Bank for International Settlements; and Fund staff estimates and projections.

$1 /$ On an annualized basis.

2/ 2007 refers to February data.

3/ Includes estimates for public debt and banking deposits held by non-residents, and non-resident claims on the nonfinancial sector.

4/ On a remaining maturity basis (scheduled amortization over the next year).

$5 /$ Short-term foreign currency debt of the public sector and the banking sector plus external debt of the nonbank sector.

6/ Excludes gold and encumbered assets.

7/ "F.C." denotes foreign currency. 


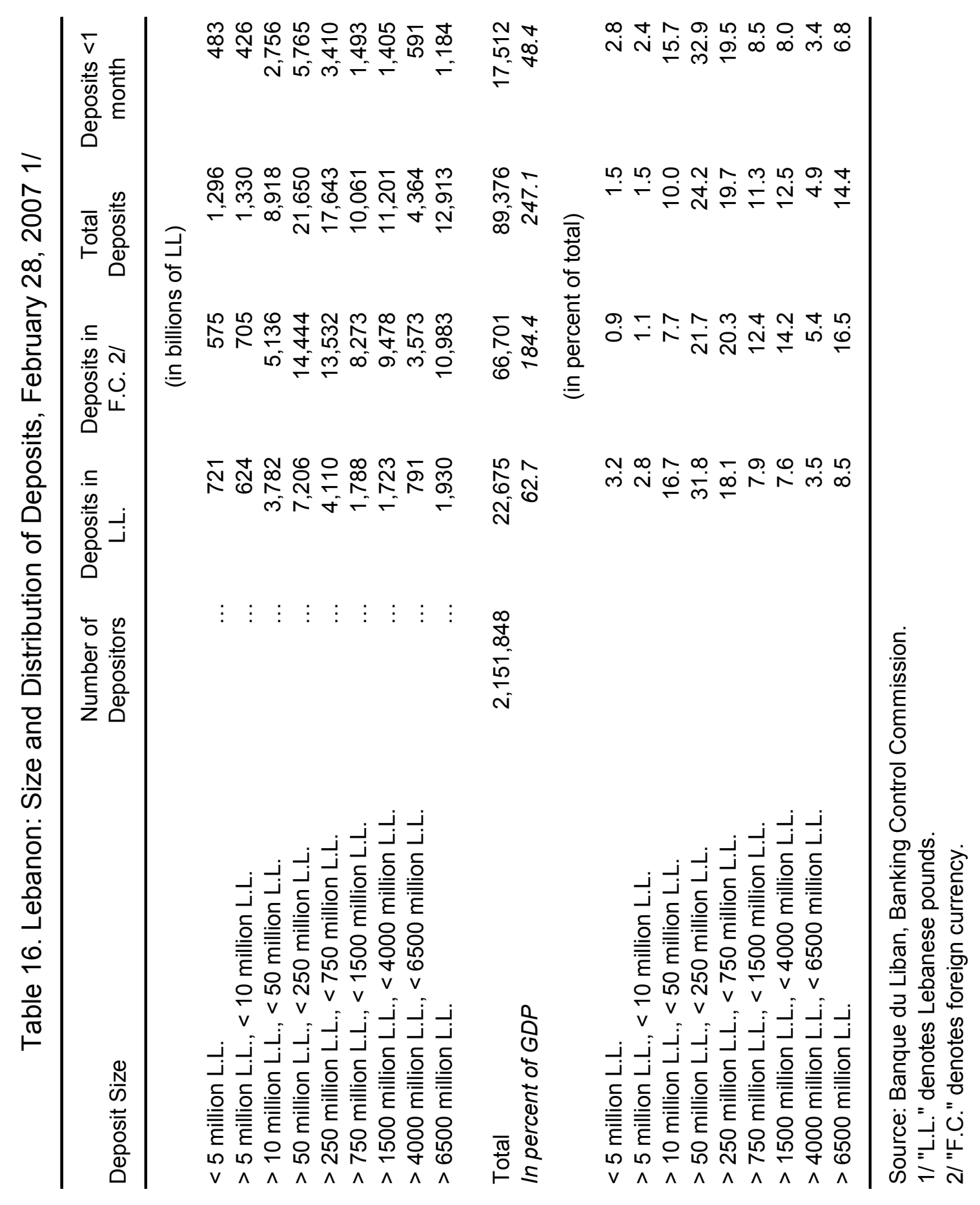




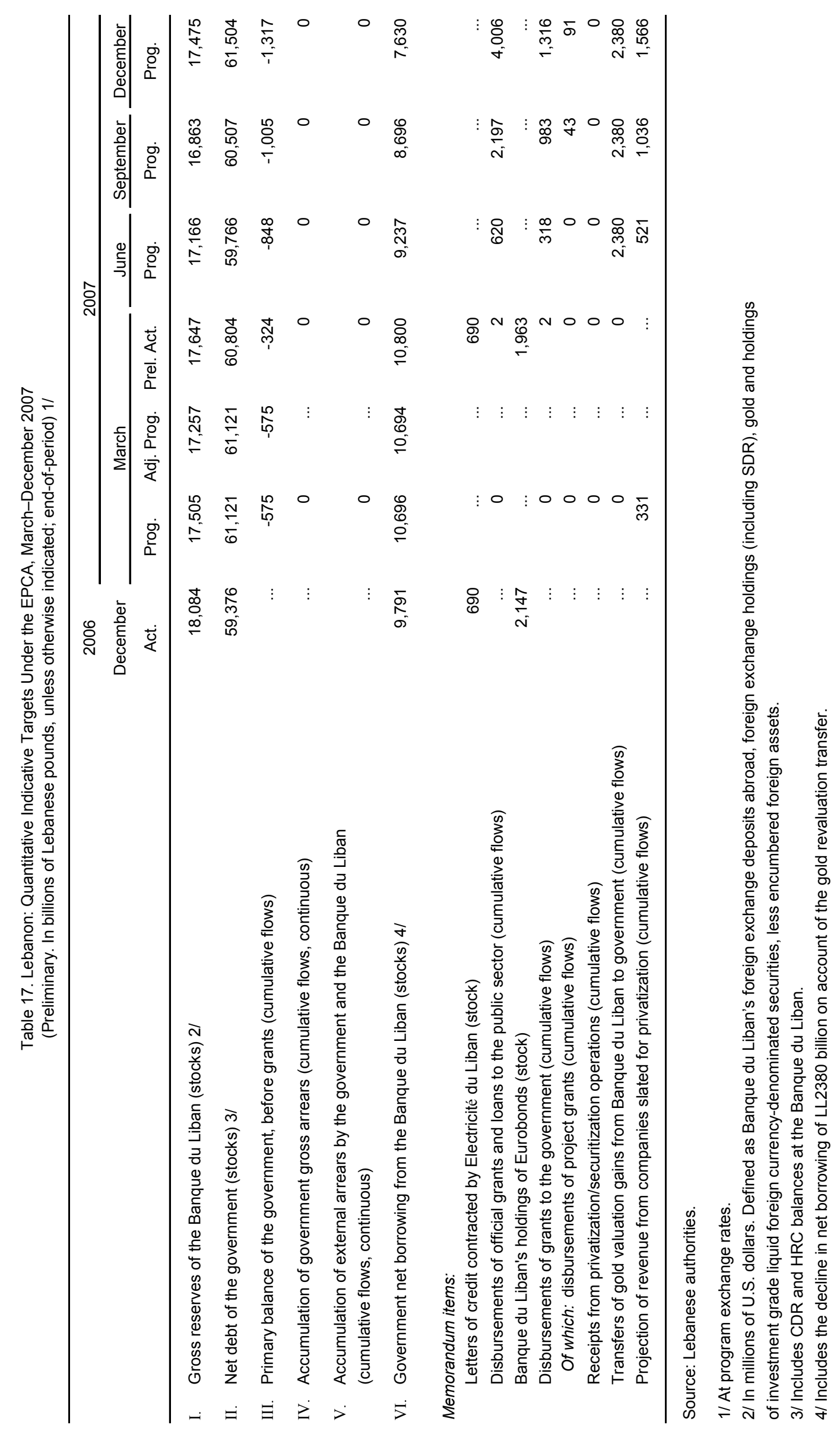


Table 18. Lebanon: Monitorable Actions for the Period March-December 2007

\begin{tabular}{|c|c|c|}
\hline Measure & Target Date & $\begin{array}{l}\text { Implementation } \\
\text { Status }\end{array}$ \\
\hline \multicolumn{3}{|l|}{ Fiscal } \\
\hline $\begin{array}{l}\text { Submit to parliament a draft } 2007 \text { budget law consistent } \\
\text { with the targeted primary balance of the central government, } \\
\text { and including detailed HRC operations and CDR } \\
\text { foreign-financed expenditures. The budget law should not } \\
\text { allow budget carryovers for expenditures for which no } \\
\text { third-part liability already exists, and treasury advances of } \\
\text { more than one month after the fiscal year. }\end{array}$ & End-June 2007 & $\begin{array}{l}\text { Draft budget } \\
\text { approved by } \\
\text { cabinet on May } 21 .\end{array}$ \\
\hline $\begin{array}{l}\text { Issue a Cabinet of Ministers decision setting a specific floor on } \\
\text { gasoline excise of LL } 300 \text { per liter of gasoline. }\end{array}$ & End-September 2007 & \\
\hline $\begin{array}{l}\text { Appoint auditor for NSSF accounts. Auditor to prepare an } \\
\text { audit plan of NSSF for 2001-06. }\end{array}$ & End-June 2007 & \\
\hline \multicolumn{3}{|l|}{ Power sector } \\
\hline $\begin{array}{l}\text { Appoint auditor for EdL accounts. Auditor to prepare an audit } \\
\text { plan of EdL for 2002-06. Publish } 2001 \text { audit report. }\end{array}$ & End-June 2007 & \\
\hline \multicolumn{3}{|l|}{ Privatization } \\
\hline $\begin{array}{l}\text { Submit to parliament the draft law to authorize the sale of the } \\
\text { mobile sector's assets and relevant operating licenses by the } \\
\text { government. }\end{array}$ & End-June 2007 & $\begin{array}{l}\text { Privatization might } \\
\text { proceed without } \\
\text { new law. }\end{array}$ \\
\hline $\begin{array}{l}\text { Issue an invitation for expression of interest (EOI) in } \\
\text { participating in the process of acquiring the licenses and } \\
\text { assets of the two mobile telephone companies (MIC1 and } \\
\text { MIC2). }\end{array}$ & End-December 2007 & \\
\hline
\end{tabular}


Table 19. Lebanon: External Financing Requirements and Sources, 2003-08

(In millions of U.S. dollars)

\begin{tabular}{|c|c|c|c|c|c|c|}
\hline & $\begin{array}{r}2003 \\
\text { Act. }\end{array}$ & $\begin{array}{r}2004 \\
\text { Act. }\end{array}$ & $\begin{array}{r}2005 \\
\text { Act. }\end{array}$ & $\begin{array}{r}2006 \\
\text { Act. }\end{array}$ & $\begin{array}{l}2007 \\
\text { Proj. }\end{array}$ & $\begin{array}{l}2008 \\
\text { Proj. }\end{array}$ \\
\hline Gross financing requirements & $-27,847$ & $-27,209$ & $-32,330$ & $-31,945$ & $-32,201$ & $-33,851$ \\
\hline External current account balance $1 /$ & $-2,615$ & $-3,332$ & $-2,926$ & $-1,568$ & $-2,987$ & $-2,911$ \\
\hline Government debt amortization & $-1,143$ & $-1,716$ & $-2,512$ & $-1,220$ & -960 & $-1,088$ \\
\hline Non-resident deposits & $-18,964$ & $-22,857$ & $-26,856$ & $-27,415$ & $-28,486$ & $-28,626$ \\
\hline Repayment of arrears & 0 & 0 & 0 & 0 & 0 & 0 \\
\hline Gross reserves accumulation (- increase) & $-5,125$ & 696 & -36 & $-1,742$ & 232 & $-1,226$ \\
\hline IMF repurchases & 0 & 0 & 0 & 0 & 0 & 0 \\
\hline Available financing & 25,752 & 27,209 & 32,330 & 31,283 & 29,657 & 32,749 \\
\hline Capital transfers (net) 1/ & 29 & 50 & 27 & 819 & 30 & 30 \\
\hline Foreign direct investment (net) & 1,722 & 2,333 & 2,629 & 2,723 & 2,297 & 6,251 \\
\hline Portfolio investment, loans, other capital & 24,038 & 26,444 & 28,759 & 26,571 & 27,330 & 26,468 \\
\hline Government (excl. exceptional financing) & 370 & 1,629 & 2,809 & 1,984 & 800 & 587 \\
\hline Banque du Liban (liabilities, net) 2/ & -18 & -3 & 474 & 1,507 & 32 & -18 \\
\hline Commercial Banks & 22,809 & 24,150 & 27,325 & 25,970 & 26,756 & 26,045 \\
\hline Non-resident deposits & 22,857 & 26,856 & 27,415 & 28,486 & 28,626 & 28,897 \\
\hline Other (net) & -48 & $-2,706$ & -90 & $-2,516$ & $-1,871$ & $-2,852$ \\
\hline Non-bank private sector (net) & 876 & 668 & $-1,849$ & $-2,889$ & -257 & -147 \\
\hline Errors and omissions & -38 & $-1,619$ & 914 & 1,170 & 0 & 0 \\
\hline Financing gap & $-2,095$ & 0 & 0 & -662 & $-2,544$ & $-1,103$ \\
\hline Exceptional financing & 2,095 & 0 & 0 & 662 & 2,544 & 1,103 \\
\hline Exceptional grants to government & 0 & 0 & 0 & 662 & 874 & 640 \\
\hline Exceptional loans to government & 2,095 & 0 & 0 & 0 & 1,593 & 463 \\
\hline IMF purchases & 0 & 0 & 0 & 0 & 77 & 0 \\
\hline Residual financing gap & 0 & 0 & 0 & 0 & 0 & 0 \\
\hline
\end{tabular}

Sources: Lebanese authorities; BIS; and IMF staff estimates and projections.

1/ Excluding exceptional grants to government.

2/ Excluding IMF. 


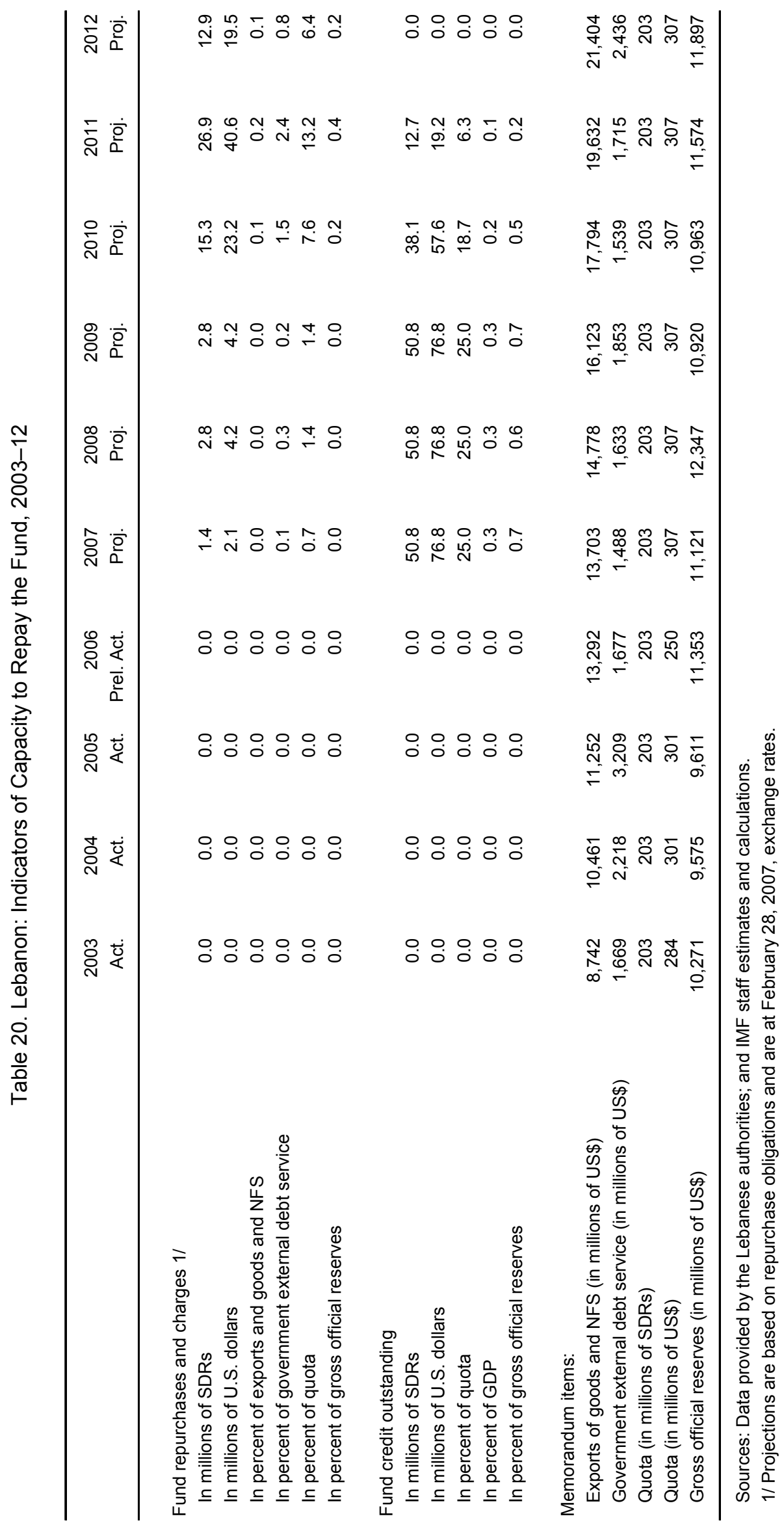




\title{
INTERNATIONAL MONETARY FUND
}

\section{LEBANON}

\section{Staff Report for the 2007 Article IV Consultation-Informational Annex}

\author{
Prepared by Middle East and Central Asia Department
}

September 17, 2007

Contents

Page

Annexes

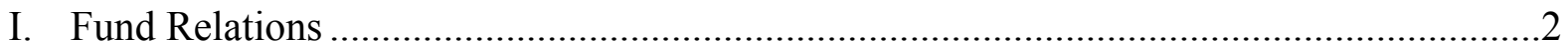

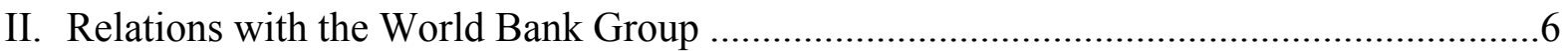

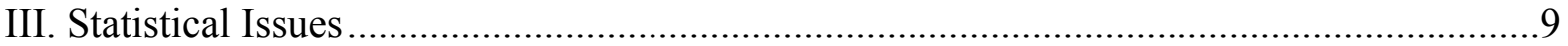




\section{Annex I. Lebanon: Fund Relations}

(As of August 31, 2007)

I. Membership Status: Joined 04/14/47; Article VIII (07/01/93).

II. General Resources Account:

Quota

Fund holdings of currency

Reserve position in Fund

III. SDR Department:

Net cumulative allocation

Holdings

IV. Outstanding Purchases and Loans:

Post-Conflict Emergency Assistance

V. Latest Financial Arrangements:

VI. Projected Payments to Fund:

(SDR million; based on existing use of resources and present holdings of SDRs)

$\begin{array}{cc}\text { SDR Million } & \text { Percent of Quota } \\ 203.00 & 100.00 \\ 234.92 & 115.72 \\ 18.83 & 9.28\end{array}$

SDR Million

4.39

Percent of Allocation

100.00

23.14

526.81

SDR Million

50.75

Percent of Quota

25.00

\begin{tabular}{lrrrrr}
\hline & \multicolumn{5}{c}{ Forthcoming } \\
\cline { 2 - 6 } & 2007 & 2008 & 2009 & 2010 & 2011 \\
\hline Principal & 0.00 & 0.00 & 0.00 & 12.69 & 25.38 \\
Charges/Interest & 0.69 & 2.71 & 2.70 & 2.58 & 1.44 \\
\hline Total & 0.69 & 2.71 & 2.70 & 15.27 & 26.82
\end{tabular}

VII. Implementation of HIPC Initiative: Not applicable

VIII. Implementation of Multilateral Debt Relief Initiative (MDRI): Not applicable 


\section{Safeguards Assessment:}

Under the Fund's safeguards assessment policy, the Banque du Liban is subject to safeguards assessment with respect to EPCA approved on April 9, 2007. The necessary documentation have been requested from the authorities on March 30, 2007. Information received so far has been partial and staff is following up with the authorities to obtain a complete set of documentation necessary for the assessment.

\section{Nonfinancial Relations}

\section{Exchange Arrangement}

The Lebanese pound is a de facto peg. Since October 1999, the Banque du Liban has intervened to keep the pound around a mid-point parity of LL 1,507.5 per \$1, with a bid-ask spread of LL+/-6.5.

\section{Article IV Consultation}

The 2006 Article IV consultation was concluded by the Executive Board on May 3, 2006 (IMF Staff Country Report No. 06/201).

\section{Financial Sector Assessment Program}

Lebanon participated in the Financial Sector Assessment Program (FSAP) in 1999, and the related report was presented to the Executive Board at the time of the Article IV consultation. A Financial System Stability Assessment (FSSA) update was conducted in 2001, and the related report similarly presented to the Executive Board at the time of the Article IV consultation.

\section{Technical Assistance}

Fiscal area-FAD has provided advice on introducing the VAT, reforming customs tariffs and income taxes, strengthening tax and customs administration, improving public expenditure management, and consolidating fiscal accounts. A fiscal ROSC report was published in May 2005. This technical assistance was well received by the ministry of finance and, notably on the VAT, its impact has been positive and substantial. Considerable needs remain in tax policy, tax administration, budget preparation, fiscal management, and public accounting and reporting. Technical assistance missions in 2005 primarily dealt with (i) the consolidation of fiscal accounts, and (ii) public liquidity management. In October 2006, a multi-sector mission provided advice on fiscal reform priorities after the conflict with Israel. 
Financial area-Over the past few years, the now Monetary and Capital Markets Department has provided technical assistance in the areas of the payments system and vulnerability indicators. The related missions undertook an assessment of compliance with Core Principles for Systemically Important Payments Systems, advised on developing systems to improve efficiency and liquidity management in public sector payments and receipts, and assisted in the elaboration of a framework for collecting and analyzing macro-prudential indicators to develop capacity to monitor systemic financial sector vulnerabilities. Progress in implementing IMF recommendations has been limited. In 2006, a mission conducted an assessment of banking sector soundness, including a stress-test exercise, with a view to developing a strategy for banking sector consolidation.

Statistical area-The Statistics Department has provided technical assistance on the development of price and balance of payments statistics, but so far, little progress has been achieved. There is no official producer price index (PPI) or consumer price index (CPI); balance of payments data remain incomplete and Lebanon does not report balance of payments data to the Statistics Department. In early 2002, a multisector statistics/GDDS mission provided an assessment of statistical needs and prepared action plans for improvements. In February-March 2007, three missions provided assistance for the compilation of the CPI. Statistical gaps remain substantial, particularly in the areas of national accounts, price statistics, and the balance of payments, but stronger political commitment to filling these gaps is needed in order for further technical assistance to be effective. 
Missions-Technical assistance missions during the last five years were:

Date

March 25-April 5, 2002

April 15-26, 2002

August 6-20, 2002

Sept. $9-23,2002$

Jan. 27-31,2003

July $29-23,2003$

July 26-August 10, 2003

Aug. 27-Sept. 8, 2003

September 24-29, 2003

March 18-29, 2004

September 6-17, 2004

October 2004

December 8-22, 2004

January 11-15, 2005

February 1-11, 2005

May 22-June 6, 2005

June 24-July 2, 2005

August 25-31, 2005

April 12-20, 2006

April 24-May 5, 2006

October 9-16, 2006

February 19-23, March 12-30, April 16-27, 2007

March 2007
Department

STA

BTS

FAD

FAD

MAE

FAD

FAD

FAD

LEG

MFD

FAD

IMF

FAD

MFD

MFD

FAD

LEG

MFD

MFD

STA/METAC

FAD

STA

STA

STA

FAD
Topic

Multisector statistics/GDDS

Database at Banque du Liban

VAT and customs administration

Income tax reform

Payment systems

Revenue administration

Public expenditure management

Tax policy

Income Tax Law

Payments and Settlement Systems and

Developing Early Warning Systems

Fiscal transparency ROSC

Creation of METAC

Tax policy

Payments and Settlement Systems and Developing Early Warning Systems

Liquidity Forecasting, Monetary Operations and the Interbank Money Market

Consolidation of Fiscal Accounts Income Tax Law

Follow-up on Early Warning Systems

An Assessment of Banking System

Government Finance Statistics

Post-Conflict Reform Challenges and priorities

Consumer Price Statistics

Consumer Price Statistics

Consumer Price Statistics

Improving Cash Management

XIV. Resident Representatives 


\section{Annex II. Lebanon: Relations with the World Bank Group}

The World Bank (Bank) presented a Country Assistance Strategy (CAS) covering fiscal years 2006-09 to the Board in December 2005. The CAS aimed at assisting Lebanon in addressing its macro-economic imbalances and its deficient public infrastructure and services, with attention to associated social and environmental issues. The key pillars of the CAS were: (i) governance for economic management and to support growth; (ii) the development of human capital and the mitigation of the poverty effects of transition; and (iii) resource and environmental management. The CAS foresaw up to $\$ 700$ million over the four year implementation period, subject to significant progress in addressing fiscal imbalances and improving the debt outlook. The major deterioration in Lebanon's fiscal balances since the hostilities temporarily placed Lebanon in the CAS low case which precludes Bank lending.

In response to its inability to lend at a time of great need for assistance, the Bank set up a Trust Fund for Lebanon (TFL) in September 2006 with a transfer of $\$ 70$ million from IBRD surplus. The funds from the TFL support projects that are geared towards addressing immediate post-conflict needs ( $\$ 30$ million for municipal development and $\$ 15$ million for water sector improvements), providing technical assistance in key reform areas (\$5 million for power sector reform) and, through IFC, an SME guarantee facility (\$15 million).

In addition, through grant financing from its post-conflict fund the Bank is providing technical assistance to the government for developing a financial tracking system for donor funds and for simplifying government procurement and financial management procedures. Upon the minister's request, the Bank also temporarily placed two staff in Ministry of Finance, focusing on local development and donor coordination and programming.

Immediately after the cessation of hostilities and at the request of the government, a multisector Bank team undertook an assessment of the economic and social impact of the hostilities and an analysis of macro and structural reform priorities for the future. The process involved intensive consultations with government officials, donor partners, the private sector and other stakeholders in Lebanon. The study was an important input into the preparation of the government's reform program which was adopted in January 2007.

At the occasion of the Paris III donors' conference on January 25, 2007, the Bank agreed to provide up to $\$ 700$ million in IBRD lending subject to and phased in with the implementation of the government's reform program. A CAS update will be presented to the Board once the Bank and the government have reached clarity on the proposed lending program.

Following interruptions in project implementation and delays in restarting work due to the hostilities, the Bank's project portfolio is progressing well. This is in large part the result of early and intensive efforts of the Bank's task teams and their Lebanese counterparts. The 
portfolio currently consists of seven projects (see Annex) totaling a commitment of \$314.6 million (of which $\$ 186.9$ million remains undisbursed).

\section{IFC's activities}

IFC began work on a post-conflict program while the hostilities were ongoing, building on previous experiences in other conflict or post-disaster situations. IFC joined the Bank's assessment team and developed a comprehensive program of investment and technical assistance in support of private sector recovery.

At the core of the program, which is now under implementation, is the Lebanon Rebuild Program in the financial sector, consisting of (1) an up to \$200 million investment program with a number of partner banks to which IFC will provide credit lines with a tenor of up to seven years and/or risk sharing facilities; this will enable these banks to lend to conflict-affected enterprises, primarily SMEs, and (2) an up to \$75 million increase in funding under IFC's existing Global Trade Finance Program in Lebanon.

In addition to investments in companies through the financial sector, IFC expects to support select real sector companies in the retail and services sectors.

Technical assistance activities continue to focus on improving the environment for the private sector, including a roundtable on techniques for recovery of microfinance portfolios and an expanded corporate governance program focusing on improving transparency and management practices in the private sector. Programs to assist SMEs in the agriculture sector and capacity-building support to entities lending to SMEs are being considered. Finally, IFC is in discussions with the government on the next steps in administrative reform which impact private sector activity, particularly in relation to issues raised by the recent administrative barriers study carried out by FIAS which identified administrative and governmental barriers to private sector development and proposed solutions to remove these. 


\section{FinANCIAL RELATIONS With THE WORLD BANK GROUP}

\section{Status of World Bank Group Operations}

As of February 28, 2007

(In millions of U.S. dollars)

\begin{tabular}{lr}
\hline Closed Projects & 15 \\
\hline & \\
\hline IBRD / IDA & 127.7 \\
\hline Total Disbursed (Active) & 10.2 \\
of which has been repaid & 570.2 \\
Total Disbursed (Closed) & 390.1 \\
of which has been repaid & 697.9 \\
Total Disbursed (Active + Closed) & 400.4 \\
$\quad$ of which has been repaid & \\
& 186.9 \\
Total Undisbursed (Active) & 0.0 \\
Total Undisbursed (Closed) & 186.9 \\
Total Undisbursed (Active + Closed) & \\
\hline
\end{tabular}

\begin{tabular}{|c|c|c|c|c|c|c|c|}
\hline \multicolumn{2}{|c|}{ Active Projects } & \multicolumn{2}{|c|}{$\begin{array}{c}\text { Last PSR } \\
\text { Supervision }\end{array}$} & \multicolumn{4}{|c|}{ Amounts (US \$ millions) } \\
\hline Project ID & Project Name & DO & IP & FY & IBRD & Canc. & Undisb. \\
\hline \multicolumn{8}{|c|}{ Status of Bank Group Activities (B8) } \\
\hline Port. Stat. & Active & & & & & & \\
\hline Country & Lebanese Republic & & & & & & \\
\hline \multicolumn{8}{|c|}{ Approval FY } \\
\hline \multicolumn{8}{|c|}{ Project ID (SPN) } \\
\hline P071113 & Communtiy Development & MU & MS & 2001 & 20.0 & & 13.5 \\
\hline P074042 & Ba'albeck Water \& Wastewater & $S$ & $\mathrm{~S}$ & 2002 & 43.5 & & 31.8 \\
\hline P050529 & Cultural Heritage and Urban Developmı & $S$ & MS & 2003 & 31.5 & & 25.5 \\
\hline P045174 & Education Development & $S$ & S & 2000 & 56.6 & 12.0 & 22.7 \\
\hline P050544 & First Municipal Infrastructure (FMIP) & $\mathrm{S}$ & $\mathrm{S}$ & 2000 & 80.0 & & 14.5 \\
\hline P103875 & FMIP additional grant & $S$ & $S$ & 2007 & 30.0 & & 30.0 \\
\hline \multirow[t]{2}{*}{ P034038 } & Urban Transport Development & $\mathrm{S}$ & $\mathrm{S}$ & 2002 & 65.0 & & 48.9 \\
\hline & & & & & 326.6 & 12.0 & 186.9 \\
\hline
\end{tabular}

\section{Status of International Finance Corporation Operations Statement of IFC's Held and Disbursed Portfolio}

(As of January 31, 2007)

(In millions of U.S. dollars)

\begin{tabular}{|c|c|c|c|c|c|c|c|c|c|c|c|c|c|}
\hline $\begin{array}{c}\text { Approval Fiscal } \\
\text { Year }\end{array}$ & $\begin{array}{l}\text { Institution } \\
\text { Short Name }\end{array}$ & $\begin{array}{l}\text { LN } \\
\text { Cmtd- } \\
\text { IFC }\end{array}$ & $\begin{array}{c}\text { ET } \\
\text { Cmtd- } \\
\text { IFC }\end{array}$ & $\begin{array}{c}\text { QL+QE } \\
\text { Cmtd- } \\
\text { IFC }\end{array}$ & $\begin{array}{c}\text { GT } \\
\text { Cmtd- } \\
\text { IFC }\end{array}$ & $\begin{array}{c}\text { RM } \\
\text { Cmtd- } \\
\text { IFC }\end{array}$ & $\begin{array}{c}\text { All } \\
\text { Cmtd- } \\
\text { Part }\end{array}$ & $\begin{array}{l}\text { LN } \\
\text { Out Bal- } \\
\text { IFC }\end{array}$ & $\begin{array}{c}\text { ET } \\
\text { Out-IFC }\end{array}$ & $\begin{array}{l}\text { QL+QE } \\
\text { Out-IFC }\end{array}$ & $\begin{array}{c}\text { GT } \\
\text { Out-IFC }\end{array}$ & $\begin{array}{c}\text { RM } \\
\text { Out-IFC }\end{array}$ & $\begin{array}{c}\text { All } \\
\text { Out-Part }\end{array}$ \\
\hline $\begin{array}{l}1993 / 1996 / \\
1999 / 2001 / 2003\end{array}$ & Byblos Bank & 8.15 & 0.00 & 0.00 & 0.00 & 0.15 & 0.00 & 8.15 & 0.00 & 0.00 & 0.00 & 0.15 & 0.00 \\
\hline $\begin{array}{l}1993 / 1994 / \\
1996 / 2001 / 2006\end{array}$ & Fransabank & 0.00 & 0.00 & 0.00 & 1.09 & 0.00 & 0.00 & 0.00 & 0.00 & 0.00 & 1.09 & 0.00 & 0.00 \\
\hline 2006 & GTFP BLF & 0.00 & 0.00 & 0.00 & 10.65 & 0.00 & 0.00 & 0.00 & 0.00 & 0.00 & 10.26 & 0.00 & 0.00 \\
\hline 2006 & GTFP Bank Beirı & 0.00 & 0.00 & 0.00 & 14.56 & 0.00 & 0.00 & 0.00 & 0.00 & 0.00 & 14.56 & 0.00 & 0.00 \\
\hline 1998 & Idarat SHV & 0.43 & 0.00 & 0.00 & 0.00 & 0.00 & 0.00 & 0.43 & 0.00 & 0.00 & 0.00 & 0.00 & 0.00 \\
\hline 2005 & SIS Adma & 8.00 & 0.00 & 0.00 & 0.00 & 0.00 & 0.00 & 6.00 & 0.00 & 0.00 & 0.00 & 0.00 & 0.00 \\
\hline Total Portfolio: & & 16.58 & 0.00 & 0.00 & 26.30 & 0.15 & 0.00 & 14.58 & 0.00 & 0.00 & 25.91 & 0.15 & 0.00 \\
\hline
\end{tabular}




\section{Annex III. Lebanon: Statistical Issues}

Gaps in the coverage of macroeconomic statistics hamper effective surveillance. In some cases, these gaps widened, owing to the effects of the 2006 conflict. In particular, there is a need for further work on the compilation of the international reserves template in order to facilitate monitoring of the gross and net international reserves and for compiling accurately the counterpart data in the central bank balance sheet. At present, it appears that most components of the monetary and financial statistics, the public debt statistics, and data on the central government budgetary accounts are available on a regular basis. However, other macroeconomic statistics (national accounts, prices, employment, general government and the rest of the nonfinancial public sector, and balance of payments) are largely estimated on the basis of partial information. Lebanon participates in the GDDS.

The availability of real sector data remains very limited, although there has been progress in compiling the national accounts. The ministry of economy and trade is currently receiving technical assistance from the French National Institute of Statistics and Economic Studies (INSEE), for the development of national accounts statistics, including the compilation of quarterly GDP data. The first set of national accounts estimates for 1997 (the base year) was published in 2003 and estimates for 1998-2004 are now available. Prior to this initiative, official national accounts statistics had not been produced since the mid-1970s, although preliminary estimates for the major components of GDP at current prices for the years 1994 and 1995 were published in October 1997. A household income survey was published in 1997. With assistance from the EU, progress is being made toward a new census on buildings, dwellings and establishments; developing and undertaking economic surveys; and conducting a household budget survey on a national level.

Consumer price indices are prepared by the Central Administration for Statistics (CAS) and private organizations on the basis of a limited basket of goods for the greater Beirut metropolitan area. The CAS index is a quarterly index based on price collection from Beirut and its suburbs. The index weights are based on the 1997 Household Budget Survey and are in need of an update. Preparations for the new index are well under way and will have national coverage.

\section{Published monthly data on the central government budgetary accounts are not} comprehensive. The published figures do not include certain transfers ${ }^{1}$ and financing data, omit foreign-financed capital expenditure, and do not cover arrears. In addition, there are no data on the widespread quasi-fiscal activities conducted by public corporations. Certain (treasury) spending is only identified ex-post, and its economic classification with a lag. However, these items are provided to the staff in the context of surveillance activities. No monthly data are available on

\footnotetext{
${ }^{1}$ These transfers apparently include those to municipalities, subsidies for the state-owned electricity company, foreign-financed capital expenditure, and payments to service providers (e.g., for waste management and cleaning services in Beirut).
} 
central government, as available data do not cover the social security funds. No sub-annual fiscal data are currently reported for publication in International Financial Statistics (IFS). Cash-based annual government finance statistics limited to the budgetary central government are published in the Government Finance statistics Yearbook(GFSY). The latest data received are for 2004, and were published in the 2006 GFSY.

\section{Lebanon has not received technical assistance in monetary and financial statistics in many} years. An assessment was undertaken during the 2002 GDDS/multisector mission which left an action plan for improvement. The monetary and financial statistics are timely although the institutional coverage is limited to the central bank and other depository corporations. However, recently questions have emerged about the central bank's statistical treatment of repos. On the basis of available data and supporting information, it appears that some Eurobond repo transactions undertaken by the central bank in mid-2005 were not recorded in its balance sheet until end-2006.

\section{Lebanon participated in the Coordinated Compilation Exercise for Financial Soundness}

Indicators (FSIs). Data and metadata on a benchmark set of indicators of the soundness of the financial system (for year-end 2005) are posted on the IMF website (http://dsbb.imf.org/Applications/web/fsi/fsicountrycategorylist/?strcode=LBN). Lebanon attached high priority to the compilation of FSIs and has produced one of the most comprehensive sets of indicators.

The balance of payments statistics (BOP) are weak. The data reflect deficiencies in the current account (unrecorded exports, underestimation of private sector services and workers' remittances), the capital account (grants), and the financial account (equity investment in the nonbank private sector, and corporate borrowing abroad). As a follow-up to the 2002 multisector mission, a technical assistance mission in November 2005, made the following recommendations: (i) the Central Bank of Lebanon and the CAS need to give high priority to extending the coverage of their existing inter-agency agreement on the share of work for data collection and compilation in balance of payments statistics; (ii) develop new data sources, with regard particularly to direct investment; (iii) adopt the definition for official reserve assets as set out in the international guidelines; and (iv) improve the periodicity of dissemination of detailed balance of payments data to a quarterly frequency.

\section{BOP source data improved with the implementation in 2003 of the International} Transactions Reporting Systems (ITRS). In July 2005, Lebanon provided STA for the first time with quarterly data for 2002-04 and with methodological notes. Data currently covering 2002-2005 are published in the IFS and the Balance of Payments Statistics Yearbook (BOPSY). However, there have been significant revisions in financial account data and the flows in the investment income-portfolio investment data (debit) for 2003 remained very large; even larger then the flows in the financial account for the same instrument. The official reserve assets are currently compiled on a gross basis consistent with the international guidelines. 


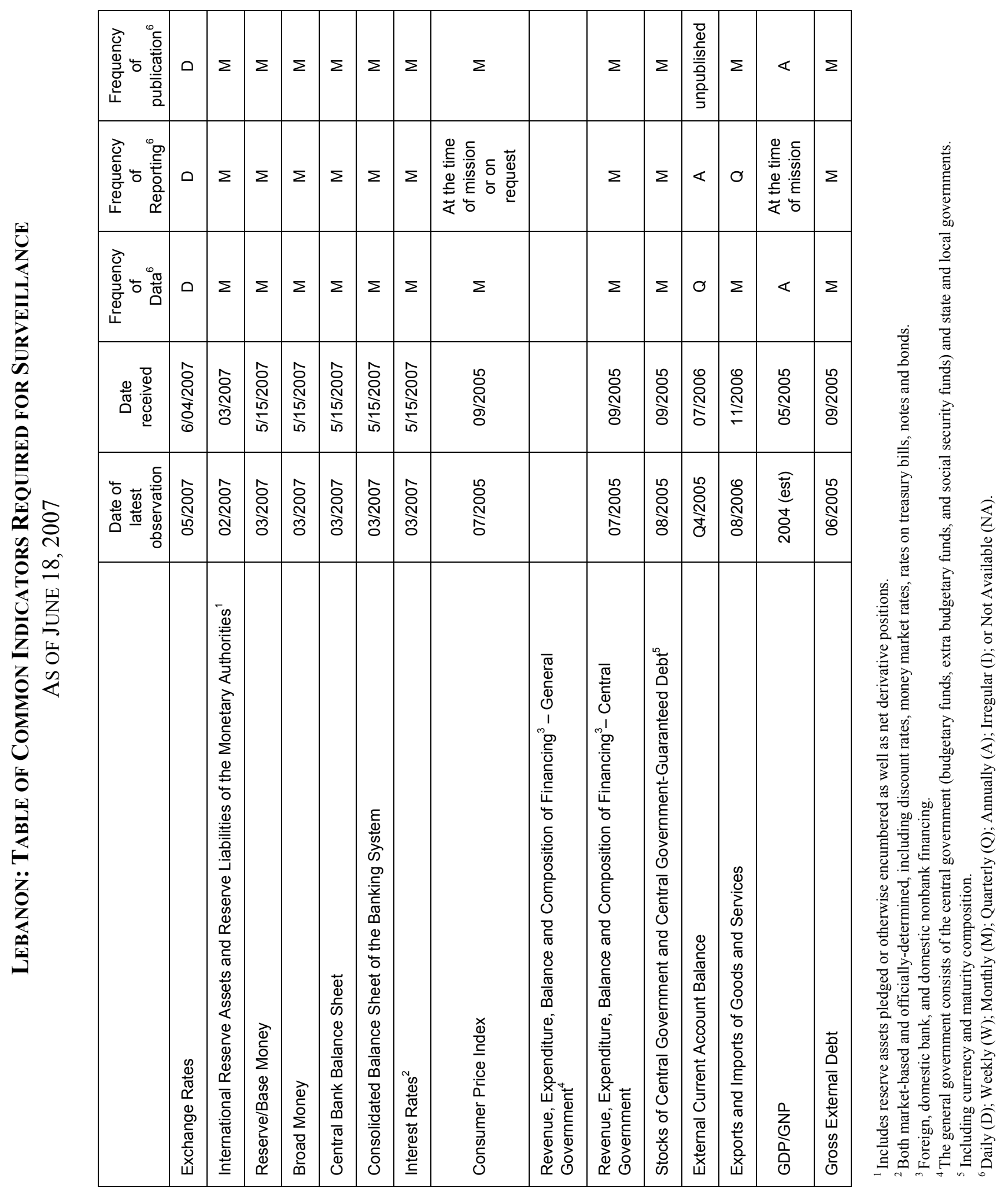




\section{Statement by the IMF Staff Representative \\ October 3, 2007}

1. This statement reports on most recent developments and their impact on the economic outlook and the staff appraisal. It complements information contained in the Staff Report for the 2007 Article IV Consultation and in the Report on Performance Under the Program Supported by Emergency Post-Conflict Assistance (IMF Staff Country Report No. 07/371).

\section{A. Recent Developments}

2. The parliamentary majority and the opposition are still in discussion over the choice of a compromise presidential candidate. The current president's term comes to an end on November 24, 2007, and the presidential election (by parliament) has been postponed to October 23. The security situation remains tense in the wake of the latest assassination of a member of the parliamentary majority on September 19. Main military operations at the Nahr al-Bared Palestinian refugee camp were successfully completed. The authorities estimate the cost of rebuilding the camp and the surrounding communities at $\$ 300-400$ million. They will be seeking additional donor assistance to fill this need.

3. The latest economic activity indicators are consistent with the earlier projection of 2 percent real GDP growth for 2007 (IMF Country Report No. 07/371). The economic recovery in the first half of 2007 was relatively modest (economic activity remained well below the very strong first half of 2006), and is unlikely to pick up momentum in the second half given the unsettled political and security situation. CPI inflation decelerated to below 2 percent year-on-year in July, consistent with the end-year inflation projection of 2 percent or lower.

4. Financial markets have weathered relatively well the domestic political uncertainty and the recent global financial turbulence. The Eurobond market has reportedly been very quiet with hardly any trading, suggesting that investors are maintaining their positions and waiting for the political situation to evolve. Eurobond spreads stood at 492 basis points on September 27, or 120 basis points higher than in mid-July. Deposit inflows have continued at a sustained pace, with broad money growth of 7 percent since the beginning of the year. Deposit dollarization is broadly unchanged at 76 percent.

5. Despite the strength of monetary growth, commercial banks provided no new net financing to the government in July and August. In the absence of fresh donor support, the government turned to central bank financing. Still, riding on the strength of capital inflows, gross international reserves increased by $\$ 300$ million in July-August to $\$ 11.9$ billion. Gross government debt stood at $\$ 40.2$ billion at end-August.

6. Government revenue and expenditure performance through July is in line with annual program objectives, but the authorities have not yet taken steps to increase gasoline excises to the level agreed for end-September (monitorable action under the 
program). At current international prices, the excise rate has declined to near zero, and reaching the target rate of $\$ 0.20$ a liter would require a 30 percent increase in gasoline retail prices. Such an increase would yield about 0.5 percent of GDP over three months. The authorities have indicated that they expect to meet the primary deficit target for 2007 even without this measure, thanks to over performance on other revenue items and lower expenditures, related in part to delays in capital spending.

7. The authorities have requested technical assistance from the IMF's Fiscal Affairs Department to prepare for the removal of various subsidies and the liberalization of gasoline prices, and to advise on the final stages of preparation of the General Income Tax (GIT). Preparations for a staff mission are underway, awaiting receipt of information on a household expenditure survey. The GIT is still under review before its submission to the Cabinet for approval. The law would have to be approved by parliament this year, if it is to come into effect in 2008 as planned. However, this deadline remains challenging as considerable preparatory administrative work is still needed to meet this objective.

8. Disbursements of Paris III budget support this year are likely to fall significantly short of program assumptions. Since June, the authorities have received a U.S. budgetary grant of \$75 million, and a \$100 million World Bank Development Policy Loan is in the process of being disbursed. They are also expecting the disbursement of $\$ 300$ million in budgetary loans from the United Arab Emirates. However, out of total outright budgetary support (loans and grants) of around $\$ 1.6$ billion projected for 2007, only \$0.6-0.9 billion is likely to be disbursed this year, mainly on account of technical and administrative reasons. Moreover, the Paris III program was premised on the expectation that a significant portion of project loans would be converted into indirect budget support (by financing existing or planned government capital projects), but negotiations on this are still under way.

9. A safeguards assessment of the Banque du Liban is currently in progress with respect to Lebanon's Emergency Post-Conflict Assistance. A mission visited Lebanon September 10-17, and a draft report is being prepared for the authorities comments prior to completion of the assessment.

\section{B. Changes to the Outlook and Implications for the Staff Appraisal}

10. Recent developments do not alter the thrust of the staff appraisal of the Article IV Staff Report:

- $\quad$ Relative to the projections underlying the Article IV Staff Report, deposit inflows have been stronger than expected, which should enable the government to increase its reliance on domestic market financing at a time when donor support appears to be falling short of program assumptions. However, as noted in the staff report, tapping the market will likely require an upward adjustment in domestic interest rates, 
particularly given the authorities' commitment to rely on central bank credit only as short-term bridge financing.

- The upward revision in oil prices relative to those assumed in the Article IV report will adversely affect the financial position of the loss-making power utility (EdL). However, the budgetary impact is likely to be felt only starting in 2008 because of lags in the financial support provided by the government to EdL.

- $\quad$ The 2007 budget target remains achievable. Early action to increase the gasoline excise would enhance the chances of meeting the target, and is also key to meeting the authorities' medium-term fiscal objectives, as spelled out in the Paris III program.

- While a resolution of the political impasse is expected to lower Eurobond spreads, Lebanon's financing costs are likely to have increased on account of the global re-assessment of risk. The adverse impact on debt sustainability reinforces the need for a prompt implementation of the adjustment and reform measures planned for 2008. Realizing the expected privatization receipts and securing donor disbursements will be important to meet projected foreign currency debt service payments of over $\$ 4$ billion in 2008 (of which $\$ 3.6$ billion for Eurobond debt service). 


\section{INTERNATIONAL MONETARY FUND}

Public Information Notice (PIN) No. 07/137

FOR IMMEDIATE RELEASE

November 26, 2007
International Monetary Fund $70019^{\text {th }}$ Street, NW

Washington, D. C. 20431 USA

\section{IMF Executive Board Concludes 2007 Article IV Consultation with Lebanon}

On October 3, 2007, the Executive Board of the International Monetary Fund (IMF) concluded the Article IV consultation with Lebanon. ${ }^{1}$

\section{Background}

Economic developments in 2006 were significantly affected by the July-August conflict with Israel. Real GDP is estimated to have been flat, with strong growth in the first half of the year offset by the disruptions during and after the conflict. Inflation increased, mainly reflecting supply shortages during the conflict and the ensuing blockade. Financial pressures associated with the conflict were managed effectively owing to the banking system's strong liquidity position. Immediately after the conflict, donors pledged US $\$ 1.7$ billion for relief and recovery (including at the Stockholm conference in August 2006), with disbursements in 2006 roughly offsetting the immediate fiscal costs of the conflict. Nonetheless, the overall fiscal deficit increased in 2006 because of rising interest expenditures and higher than expected transfers to the power company, Electricité du Liban. Government debt rose to over US\$40 billion (178 percent of GDP) at end-2006.

The economic situation continues to be overshadowed by the political stalemate and episodes of violence, including the assassination of a member of parliament in June 2007 and a fifteen-week long battle between the army and Fatah al-Islam militants in northern Lebanon. In this environment, economic activity, including tourism, remains

\footnotetext{
${ }^{1}$ Under Article IV of the IMF's Articles of Agreement, the IMF holds bilateral discussions with members, usually every year. A staff team visits the country, collects economic and financial information, and discusses with officials the country's economic developments and policies. On return to headquarters, the staff prepares a report, which forms the basis for discussion by the Executive Board. At the conclusion of the discussion, the Managing Director, as Chairman of the Board, summarizes the views of Executive Directors, and this summary is transmitted to the country's authorities.
} 
subdued, and real GDP is expected to rebound only slowly in 2007. Inflation as measured by the Consumer Price Index declined through mid-2007 from its 2006 peak, notwithstanding the depreciation of the U.S. dollar to which the currency is pegged. Trade flows have recovered from the near- standstill during and after the conflict, with the trade deficit in the first half of 2007 deteriorating slightly relative to the same period in 2006.

The financial system has remained resilient to the political uncertainty. Owing to moderate capital inflows and slow deposit growth as well as limited donor disbursements, international reserves declined by US $\$ 300$ million to US $\$ 11$ billion in the first quarter. However, deposit growth accelerated subsequently, and by end-June broad money was already $4 \frac{1}{2}$ percent higher than prior to the conflict with Israel, with international reserves more than recovering to US\$11.6 billion at end-June 2007. Still, the political deadlock has increased risks, as reflected by Eurobond spreads of 495 basis points as of end-August and deposit dollarization of around 76 percent, significantly higher than prior to the 2006 conflict. The recent turbulence in international financial markets has not had, up to now, a significant impact on Lebanon. While spreads have increased by around 80 basis points between mid-July and mid-August, there has been no pressure on the currency, and deposit inflows have remained robust, though at a more moderate pace than in the second quarter.

\section{Executive Board Assessment}

Directors commended a good policy performance under the program supported by the Fund's Emergency Post-Conflict Assistance. The economy is recovering despite the persistent high oil price and political uncertainty, inflationary pressures have eased, and gross international reserves have increased further.

At the same time, Directors underscored that major challenges remain, including the large debt overhang, financial and macroeconomic vulnerabilities, and high energy costs. They considered the authorities' 2007-12 reform program to be an ambitious and credible strategy for meeting these challenges. They acknowledged that implementation of the program will be a challenging task given the difficult political and security situation. While Directors were encouraged by the authorities' reiterated commitment to reform, they noted that the authorities will need to pay close attention to the timing of the reform process. Directors stressed that donor support is an important pillar of the reform strategy, and called for timely disbursement of such support.

Directors welcomed the authorities' success in containing the primary fiscal deficit in the first half of 2007. They emphasized the need for determined action to achieve the 2007 budget deficit target and the medium-term debt reduction objectives. In this regard, Directors commended the steps taken to initiate reforms in the social security and power sectors. They encouraged the authorities to give priority to raising gasoline excises as soon as the political situation allows. 
Directors welcomed the fiscal adjustment and privatization plans for 2008. They noted the planned increases in the value-added tax and the tax on interest income in 2008, the preparations for the introduction of a global income tax in 2008, and the administrative reforms underway. Directors emphasized that further progress is needed on energy sector reforms to realize the expected medium-term expenditure savings. They supported the planned privatization of the telecom sector as crucial to the success of the reform strategy.

Directors stressed the importance of strengthening public financial management. They encouraged the authorities to follow up on their action plan to improve the cash and budget management functions. While they called for expenditure restraint, Directors advised against across-the-board expenditure cuts, and recommended that efforts focus instead on curtailing low-priority current spending rather than capital spending. Directors also emphasized the need to strengthen the social safety nets. They welcomed the establishment of a debt management office.

Directors noted that the monetary policy framework has served Lebanon well, especially in helping to maintain financial stability in the face of disruptions in international financial markets. They underscored that central bank financing of the government will need to be gradually reduced in order to safeguard the central bank's balance sheet, and supported the authorities' intentions to rely increasingly on market finance.

Going forward, Directors supported the planned introduction of transparent short-term monetary instruments, and underscored the importance of allowing greater interest rate flexibility in Treasury bill auctions. Directors advised that the central bank refrain from quasi-fiscal activities, and supported the establishment of a joint working group in the Ministry of Finance and the central bank to better coordinate interventions in the financial market.

Directors considered that the exchange rate peg to the U.S. dollar has helped maintain financial stability without impairing competitiveness. They noted that gross international reserves, combined with the banking system's liquidity cushion, appear to be sufficient to meet temporary pressures on the exchange rate. Directors agreed that the real effective exchange rate appears broadly in line with fundamentals. Going forward, Directors stressed that continued sound macroeconomic policies and structural reforms, particularly full implementation of fiscal adjustment plans, will be essential to support the exchange rate peg.

Directors noted that the banking sector, though profitable and well capitalized, faces vulnerabilities associated with high sovereign exposure, maturity mismatches, and the high degree of dollarization. They agreed that a reduction in the government debt will be crucial to reduce these vulnerabilities, but also emphasized the need to strengthen risk 
management, diversify loan portfolios, and enhance cross-border supervision. Directors welcomed commercial banks' readiness to adopt Basel II requirements in 2008.

Public Information Notices (PINs) form part of the IMF's efforts to promote transparency of the IMF's views and analysis of economic developments and policies. With the consent of the country (or countries) concerned, PINs are issued after Executive Board discussions of Article IV consultations with member countries, of its surveillance of developments at the regional level, of post-program monitoring, and of ex post assessments of member countries with longer-term program engagements. PINs are also issued after Executive Board discussions of general policy matters, unless otherwise decided by the Executive Board in a particular case. 
Lebanon: Selected Economic Indicators, 2003-08

\begin{tabular}{|c|c|c|c|c|c|c|}
\hline & $\begin{array}{l}2003 \\
\text { Act. }\end{array}$ & $\begin{array}{l}2004 \\
\text { Act. }\end{array}$ & $\begin{array}{l}2005 \\
\text { Act. }\end{array}$ & $\begin{array}{c}2006 \\
\text { Prel. Act. }\end{array}$ & $\begin{array}{l}2007 \\
\text { Proj. }\end{array}$ & $\begin{array}{l}2008 \\
\text { Proj. }\end{array}$ \\
\hline Domestic economy & \multicolumn{6}{|c|}{ (In percent) } \\
\hline Change in real GDP & 4.1 & 7.4 & 1.0 & 0.0 & 2.0 & 3.5 \\
\hline Change in consumer prices (period average) $1 /$ & 1.3 & 1.7 & -0.7 & 5.6 & 3.5 & 2.5 \\
\hline External economy & \multicolumn{6}{|c|}{ (In billions of U.S. dollars; unless otherwise indicated) } \\
\hline Exports, f.o.b. & 1.7 & 2.1 & 2.3 & 2.8 & 3.2 & 3.6 \\
\hline Imports, f.o.b. & -6.5 & -8.5 & -8.4 & -8.5 & -10.0 & -10.8 \\
\hline Current account balance & -2.6 & -3.3 & -2.9 & -1.4 & -2.5 & -2.4 \\
\hline In percent of GDP & -13.2 & -15.5 & -13.6 & -6.2 & -10.6 & -9.4 \\
\hline Capital and financial account balance & 5.7 & 4.3 & 2.0 & 2.0 & 0.7 & 3.2 \\
\hline Overall balance & 3.0 & -0.7 & 0.0 & 1.7 & -1.8 & 0.8 \\
\hline Gross official reserves, exc. Gold & 10.3 & 9.6 & 9.6 & 11.4 & 11.1 & 12.3 \\
\hline Change in real effective exchange rate (in percent) & -10.7 & -6.8 & -4.1 & 2.2 & $\ldots$ & $\ldots$ \\
\hline Financial variables & \multicolumn{6}{|c|}{ (In percent of GDP; unless otherwise indicated) } \\
\hline Budget balance 1/ & -13.3 & -8.6 & -8.4 & -11.1 & -12.2 & -9.1 \\
\hline Gross government debt & 169 & 167 & 179 & 178 & 173 & 143 \\
\hline Of which: in foreign currency & 78.7 & 85.6 & 88.9 & 89.9 & 90.2 & 79.0 \\
\hline Change in broad money $2 /$ & 15.5 & 12.3 & 3.5 & 6.4 & 5.0 & 5.0 \\
\hline Two-year Lebanese pound treasury bill rate $3 /$ & 8.0 & 7.9 & 8.5 & 8.7 & 8.7 & 8.5 \\
\hline
\end{tabular}

Sources: Lebanese authorities; and IMF staff calculations.

1/ Overall balance, after grants, on a checks-issued basis.

2/ In percent, end-of-period.

3/ Primary market rate, in percent, end-of-period. 


\section{Statement by A. Shakour Shaalan, Executive Director for Lebanon October 3, 2007}

1. On behalf of the Lebanese authorities, I would like to express my appreciation to the staff, Management, and the Executive Board for their continued constructive engagement with Lebanon. The authorities view the consultation process, as well as the continued provision of technical assistance, as being of great value to the country.

2. The authorities remain committed to their ambitious medium-term reform program, which was presented to donors at the Paris III conference in January 2007. The program, developed in close cooperation with the Fund, aims at raising growth, improving living standards, and reducing Lebanon's large debt overhang and financial vulnerabilities, while carefully considering the timing of adjustment measures, given the current difficult post-war environment. The program includes a strong phased fiscal adjustment which, along with privatization proceeds and Paris III contributions, should gradually strengthen the primary balance and result in a significant reduction in the debt-to-GDP ratio over the medium term. The institutional structure that the government has put in place to monitor the implementation of the Paris III program aims at ensuring sustainability of the reform momentum generated under Paris III. The authorities acknowledge, however, that proper implementation of the program remains subject to improved political and security conditions.

\section{Recent Developments}

3. The current year continues to be particularly difficult, with persistent serious political tension and security concerns ahead of the presidential election, which is expected to be held by November 2007. Notwithstanding the daunting political and security challenges, economic indicators point to a slow recovery from the 2006 Israeli attack on Lebanon. Real GDP is expected to rebound to about 2 percent in 2007. CPI inflation is projected to fall to around 2 percent by year's end, following price pressures in the summer of 2006, due to supply shortages related to the war and the subsequent blockade. The financial system remains resilient. Gross international reserves recovered to about $\$ 12$ billion at end-August, supported by strong deposit inflows. Moreover, trade flows have resumed after an interruption occasioned by the 2006 war.

4. Against this background, the authorities continue to consider the Fund-supported Emergency Post-Conflict Assistance (EPCA) to be critical in supporting their efforts to implement the 2007 agenda, thereby paving the way for more ambitious fiscal adjustment and structural reforms in subsequent years. Performance under the EPCA was strong, with all end-March 2007 quantitative targets observed, with the exception of the ceiling on government borrowing from the Banque du Liban (BdL), which was exceeded by a small margin. Indeed, in the first months of 2007, the government had to solicit further direct financing from the BdL, amidst serious political tensions and ensuing tight market 
conditions, as commercial banks failed to roll over maturing government paper. Moreover, all the quantitative targets for the second quarter of 2007 were observed with large margins.

5. Economic policy and performance in the first half of 2007, particularly the strong revenue collection and continued expenditure restraint, augur well for the achievement of the program's end-year quantitative fiscal targets. However, actual disbursements of pledges committed at the Paris III and Stockholm conferences have so far fallen well below EPCA assumptions. While of the total US\$7.6 billion pledged at the Paris III conference, agreements have been signed for about US\$3.4 billion, out of US\$1.6 billion in budgetary support pledged for 2007, only US\$0.6-0.9 billion is likely to be received this year. At the same time, US\$175 million has been disbursed to date and a US\$100 million World Bank Development Policy Loan is in the process of being disbursed. Should disbursement fail to accelerate considerably in the last quarter of 2007 in line with Paris III pledges, the authorities would find it extremely difficult to identify additional fiscal measures to offset the resulting sizable shortfall, as rightly pointed out by staff. This outcome would weigh on the government's indebtedness.

6. Notwithstanding their strong commitment to the objectives of the EPCA and the medium-term reform agenda, the authorities are aware of persistent vulnerabilities. In the short-term, the economy remains vulnerable to swings in confidence. Moreover, the political deadlock has increased risks, as reflected by Eurobond spreads and deposit dollarization, which remain higher than prior to the 2006 war. Looking ahead, despite the strong fiscal adjustment and structural reforms embedded in the authorities' program to bring down the debt-to-GDP ratio significantly, the debt dynamics are likely to remain fragile and vulnerabilities high. Accordingly, in addition to the commitment of the authorities to pursue their ambitious reform agenda under the EPCA and beyond, continued strong international support remains essential to help Lebanon reduce its economic vulnerabilities. In particular, it is important that donors fully carry through their financial commitments made at the Paris III conference, in a timely fashion, and in line with the authorities' macroeconomic objectives and policy priorities. The authorities continue to actively seek flexibility from donors to convert project loans pledges into budgetary support to further reduce the debt burden. They are particularly grateful for the Fund's assistance in this regard. 


\section{Fiscal Policy and Reforms}

7. Sound fiscal management to date in 2007 succeeded not only in avoiding a deterioration in the fiscal position, but also in improving the primary balance, while attempting to meet the large social and reconstruction needs of the Lebanese population. The first and second quarter performance was within the EPCA targets. Stronger than projected revenue collection, and containment of expenditures below the EPCA targets, helped contain the primary deficit and the accumulation of net debt. Moreover, the cabinet approved the draft budget for 2007, which includes the foreign financed component of the Council of Development and Reconstruction and activities of the Higher Relief Council.

8. In spite of unanticipated and sizeable conflict-related expenditure, the primary budget deficit, excluding grants, is expected to be contained at 3.7 percent of GDP at end-2007, as programmed, supported by higher than projected revenues. On the revenue front, the authorities remain committed to introducing a floor on gasoline excises of $\$ 0.20$ per liter. Given the continued political instability, however, implementation of this measure may have to be postponed until after the presidential elections. Uncapping domestic gasoline prices in a context of high international oil prices would translate in a substantial hike in gasoline retail prices, which, in the present political and economic environment, may seriously exacerbate existing tensions. It is well to note that delaying implementation of this measure will not jeopardize the primary balance target for 2007, as envisaged under the EPCA. Indeed, the potential loss stemming form a delayed introduction of a floor on gasoline excises has already been largely compensated for by increases in other sources of revenue, including VAT, customs, income tax, and telecom transfer. Preliminary estimates indicate that the end-September 2007 revenue performance already exceeds the end-of-year target under the EPCA. The authorities have also requested technical assistance from the Fund to prepare for the removal of various subsidies and the liberalization of gasoline prices.

9. Important progress has been achieved in preparing the fiscal adjustment effort envisaged for 2008. On the revenue side, the draft 2007 budget already provides for increasing the value-added tax rate and the tax on interest income as of 2008. The draft Global Income Tax law is near completion and should be ready for submission to parliament by year end. In addition, the review of the Tax Procedure Code has been finalized by the parliamentary committees, and is awaiting ratification by Parliament. Ongoing revenue administration reforms, including the introduction of a medium taxpayer office, new audit procedures, and the update of the real estate tax database, are expected to yield revenue gains. On the expenditure side, the authorities' medium-term program aims at gradually eliminating transfers to the public sector, which hinges on reforming the energy and social sectors that have drained budget resources over the years. In this connection, and in close cooperation with the World Bank, reform plans for Electricité du Liban (EdL) and the 
National Social Security Fund (NSSF) are being finalized. ${ }^{1}$ Administrative measures include better cooperation and information sharing across ministries and the planned establishment of a debt management office, in addition to measures aimed at strengthening treasury and debt management capabilities. The authorities have achieved further progress in implementing the public financial management reform plan developed with Fund assistance, and aimed at enhancing budget monitoring and control procedures. A pilot project for program budgeting at the Ministry of Public Health was also introduced in the draft 2008 budget.

\section{Monetary Policy and Banking Sector Policies and Reforms}

10. The monetary policy framework has enabled the authorities to effectively control financial pressures. The exchange rate peg continues to serve the economy well by providing a firm anchor to financial stability. It proved crucial given balance sheet risks related to widespread dollarization and the government's high foreign currency debt servicing obligations. The debt overhang and the large external current account deficits are the counterpart of fiscal imbalances, as well as temporary factors related to the post-conflict environment. They would be addressed by implementing the Paris III fiscal adjustment program. In this context, the authorities are of the view that the current exchange level is appropriate, and agree with staff's assessment outlined in Box 3. Furthermore, they are confident that Lebanon's competitiveness could significantly benefit over the medium term from the planned structural reforms.

11. Interest rate stability has largely contributed to facing financial pressures, reflected in higher dollarization and pressures in the foreign exchange market. Admittedly, these conditions have required the BdL to occasionally resort to various financial and long-term monetary instruments to manage liquidity and safeguard international reserves. These included the issuance of dollar-denominated certificate of deposits, special discount windows, and swaps. While the authorities believe that the BdL could temporarily provide financing to the government under tight market conditions, in line with its mandate to maintain financial stability, they concur with staff that prolonged shortfalls in market demand for government paper would have to be met by raising treasury bills rates. The authorities are of the view that flexible interest rates are essential to counter further increases in dollarization, which might adversely affect the central bank's foreign reserves levels. They consider that an appropriate spread between returns on foreign currency and Lebanese

\footnotetext{
${ }^{1}$ Key progress has been achieved in reforming EdL, including: (i) the appointment of an auditor for the 2002-2006 fiscal years, and the publication of the audited 2001 financial statements; (ii) the appointment of international consultants at the Ministry of Energy and Water, EdL and the Higher Council for Privatization, to assist in implementing the restructuring of the electricity sector; (iii) the appointment of a transaction advisor for the sale of Beddawi power plant in Northern Lebanon and the investment in new capacity by the private sector; (iv) the signature of an agreement with Egypt for the import of Natural Gas to the Beddawi power plant in the North; and (v) the appointment of a consultant to prepare a generation and transmission Master Plan for the energy sector.
} 
pounds in the domestic market should thus be assured in order for commercial banks to subscribe in government paper. On the current account level, an adequate spread between domestic returns on dollar investments and international rates would help ensure the necessary inflows of capital into the economy. The authorities are of the view, however, that an upward adjustment in domestic interest rates at this stage may not attract sufficient market financing given the existing uncertainties, and thus have an adverse signaling effect. Once more stable and predictable market conditions prevail, the central bank should be in a better position to maintain price stability using short-term monetary instruments. This would help strengthen its balance sheet and reduce its cash losses. Going forward, fiscal adjustment and improved confidence would help reduce dollarization, which would facilitate a further buildup of net international reserves and strengthen the BdL's income position. Improved political and security conditions, however, remain essential to the reform of the monetary policy framework.

12. The banking sector remains profitable, well-capitalized, and well-supervised. However, vulnerabilities are high, as reflected in domestic bank's high exposure to the sovereign, the substantial maturity mismatch on their books, as well as the high degree of dollarization which exposes them to credit risk. In this context, and given potential systemic risks between the fiscal and the financial sector, the authorities welcome the commercial banks' focus on private sector lending and their strategy of regional diversification. The regulatory and supervisory framework has appropriately adapted to these developments. This is evidenced in the circular issued by the banking control commission in 2006, raising the limits on the exposure of Lebanese banks to non-resident borrowers, and the progress in developing memoranda of understanding on consolidated supervision with supervisory authorities in countries where Lebanese banks are expanding. Commercial banks are expected to further strengthen risk management with the introduction of Basel II standards in 2008.

\section{Other Structural Reforms}

13. Reforming the social and energy sectors, which have drained the government's financial resources for years, is pivotal to the medium-term structural reform agenda. Reforms to address imbalances, and possible contingent liabilities, in the pension and health system are being developed. A draft pension law, providing for transforming the private pension systems from an end-of-service allowance to a fully funded system, has been submitted to parliament. Furthermore, the authorities, supported by the World Bank, are looking into options for addressing the losses of the health fund of the NSSF. The government is currently finalizing a comprehensive energy sector reform plan in close cooperation with the World Bank, with the objective of restructuring EdL to pave the way for partial privatization. The main reform measures envisaged for 2008 include: (i) the completion of an audit of EdL accounts for 2002-2006, (ii) the completion of EdL's asset registration and valuation, (iii) the corporatization of the company, (iv) the launch of a pilot project for remote meter installation and distribution management by private operators, 
(v) launching the privatization of the Beddawi power plant, and (vi) soliciting private sector investment in new capacity.

14. The privatization of the telecommunications sector is expected to start as early as October 2007. A legal opinion by the ministry of justice concluded that the law for the sale of the fixed assets of the two state-owned mobile phone operators was no longer necessary. Accordingly, the government expects that invitations for expressions of interest for the two companies to be issued by the end of 2007. The authorities are committed to undertaking the privatization of the mobile sector companies through a transparent public offering. The privatization of the fixed line, as well as a third mobile license, are planned to be launched in 2008.

15. In conclusion, looking forward, for the reform agenda for 2008 and beyond to be successfully implemented, three critical conditions have to be met. First, a satisfactory outcome of the current ongoing presidential elections. Second, the international community's delivery of aid committed under Paris III. And finally, a reasonable environment of peace and security in Lebanon and the region as a whole. 